\title{
Instructors' self -perceived pedagogical principle implementation in the online environment
}

Jinsong Zhang

West Virginia University

Follow this and additional works at: https://researchrepository.wvu.edu/etd

\section{Recommended Citation}

Zhang, Jinsong, "Instructors' self -perceived pedagogical principle implementation in the online environment" (2006). Graduate Theses, Dissertations, and Problem Reports. 2712.

https://researchrepository.wvu.edu/etd/2712

This Dissertation is protected by copyright and/or related rights. It has been brought to you by the The Research Repository @ WVU with permission from the rights-holder(s). You are free to use this Dissertation in any way that is permitted by the copyright and related rights legislation that applies to your use. For other uses you must obtain permission from the rights-holder(s) directly, unless additional rights are indicated by a Creative Commons license in the record and/ or on the work itself. This Dissertation has been accepted for inclusion in WVU Graduate Theses, Dissertations, and Problem Reports collection by an authorized administrator of The Research Repository @ WVU.

For more information, please contact researchrepository@mail.wvu.edu. 


\title{
INSTRUCTORS' SELF-PERCEIVED PEDAGOGICAL PRINCIPLE IMPLEMENTATION IN THE ONLINE ENVIRONMENT
}

\author{
Jinsong Zhang \\ Dissertation Submitted to the \\ College of Human Resources and Education \\ at West Virginia University \\ in partial fulfillment of the requirements \\ for the degree of \\ Doctor of Education \\ in \\ Technology Education \\ Richard T. Walls, Ph.D., Chair \\ Margaret K. Glenn, Ed.D. \\ Daniel Hartley, Ed.D. \\ Deborah J. Hendricks, Ed.D. \\ David L. McCrory, Ph.D. \\ Department of Advanced Educational Studies \\ Morgantown, West Virginia \\ 2006
}

Keywords: distance education, instructional technology, online instruction, pedagogy Copyright (C) 2006 Jinsong Zhang 


\begin{abstract}
Instructors' Self-Perceived Pedagogical Principle Implementation in the Online Environment by Jinsong Zhang
\end{abstract}

The purpose of this study was to explore and describe the experience of undergraduate faculty members who participated in the practice of online distance instruction. This study explored instructor's perception of their implementation of pedagogical principles in the online environment, identified factors that influenced their implementation of the principles, and explored the relationship between the influencing factors and the online implementation of the Seven Principles.

Research shows that the implementation the Seven Principles for Good Practice in Undergraduate Education (Chickering \& Gamson, 1987) varied significantly from one principle to another. Overall the least endorsed of the Seven Principles were Encourage Cooperation Among Students and Encourage Student-Faculty Contact. In contrast, the most endorsed of the Seven Principles were Communicate High Expectations.

This study reveals that Instructional Strategies and Technology Features positively influenced online implementation of the Seven Principles. Time \& Distance and Lack of Student Involvement negatively influenced online implementation of the Seven Principles.

Results indicate that significant difference existed in the implementation of the Seven Principles between participants teaching courses in the area of Humanities and Science and Technology. Participants in the Humanities group reported significantly higher implementation of the Seven Principles than participants in the Science and Technology group. 
To my parents Enxi Zhang and Wenzhi Song 献给我的父母章恩熙, 宋文智 


\section{ACKNOWLEDGEMENTS}

I wish to acknowledge the assistance of a number of people who contributed significantly to the successful completion of this dissertation. I want to thank my doctoral committee: Dr. Richard Walls, Dr. Margaret Glenn, Dr. Daniel Hartley, Dr. Deborah Hendricks, and Dr. David McCrory. I am grateful to their valuable comments and suggestions. I was fortunate to have such a supportive committee and to be associated with this fine collection of professionals. In particular, I wish to thank Dr. Richard Walls, my research advisor, for his advice and expert opinion on the dissertation project. I greatly appreciate his guidance throughout the course of this work. His patience and understanding have been invaluable for the completion of this project.

I would like to extend my sincerest appreciation to other individuals who contributed to the project. I am indebted to Dr. Tongshan Chang and Dr. Roxann Humbert for their insightful inputs and ideas, to my expert panel members, Dr. Paul Chapman, Dr. Georgy Kelley, Mr. Chad Mezera, Dr. John Oughton, Ms. Elizabeth Quintana, Dr. Rusty Russel, and Dr. Chris Weigandt for their comments about the survey instrument, and to the online instructors at West Virginia University, Potomac State College of West Virginia University, and West Virginia University at Parkersburg. This project would never come to its completion without their cooperation and participation. I am also obliged to Mr. Allam Omar of Admissions and Records, Mr. David Olsen of WVU Web Services, and Dr. C. B. Wilson of Academic Affairs for their generous assistance.

I am grateful to my wife, Hong, and our son, Minke for their love, support, patience, and sacrifice. Their love and encouragement were critical in bringing me to completion of the degree and the long way in pursuit of a doctorate. At this moment I could not help recalling one of the many incidents that occurred in the 170-mile commuting life in the past 39 months. The incident evolved on the morning of December 3, 2003 when Hong left home for her visa revalidation interview in Ottawa. She was desperate to be at the bedside of her mother who almost lost her life in a severe heart attack and stroke. At about 9:00 p.m., I left the classroom and set off into the mountains. But soon after I got on the highway, I was caught in a blizzard. I struggled for nearly six hours in the Appalachian Mountains and arrived at about 2:30 in the morning to find nobody home. On Friday evening Hong called home to tell us that she was caught in the snow storm and her car slide, skipped, hit a rail-guard on the highway. She had to pull off into a motel and wait for the snow to be cleared before she could continue her driving. I am happy and grateful that we have overcome all the hardship and difficulties of yesterday, and we are ready for tomorrow. 


\section{TABLE OF CONTENTS}

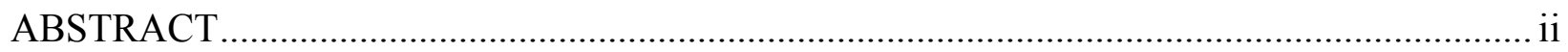

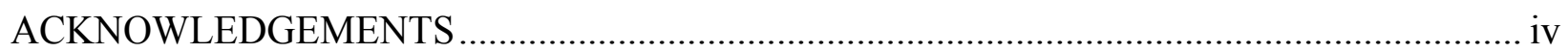

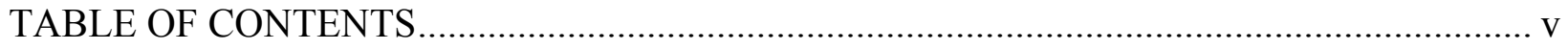

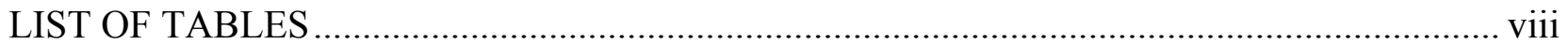

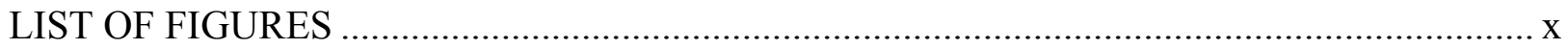

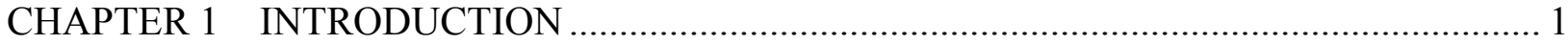

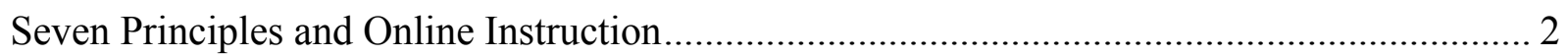

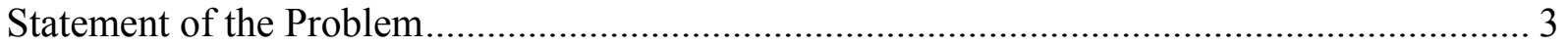

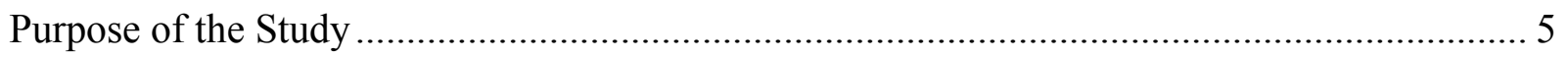

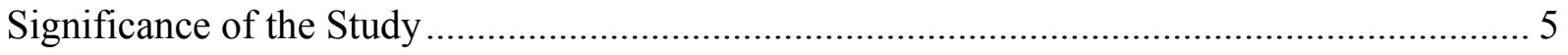

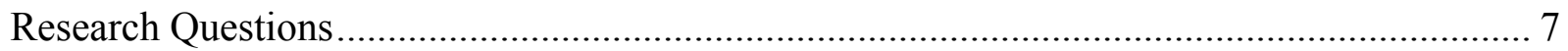

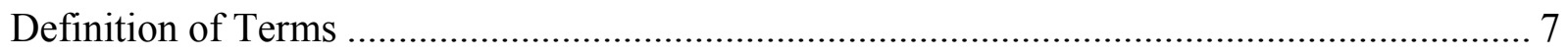

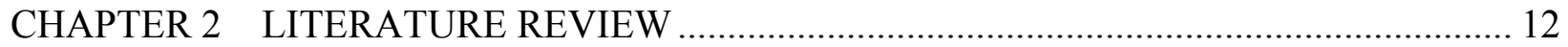

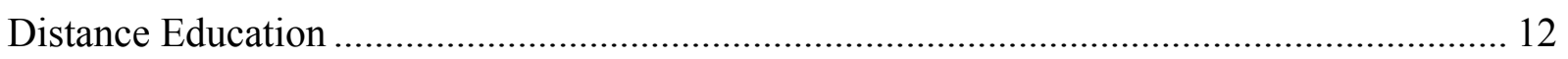

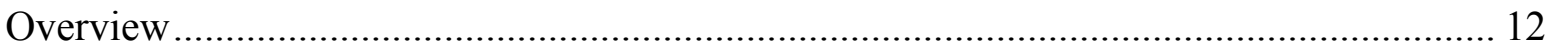

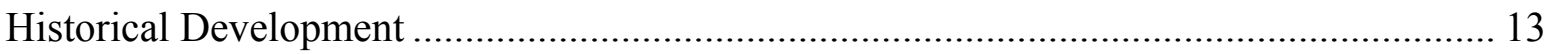

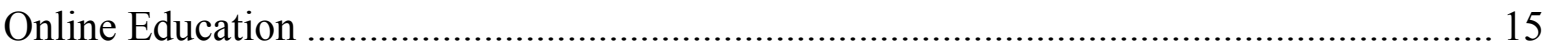

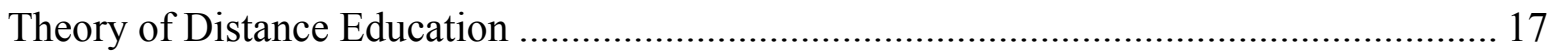

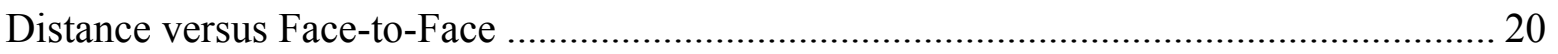

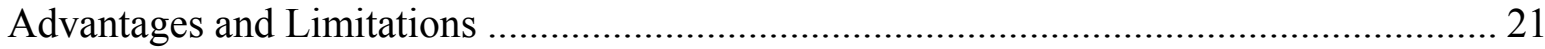

Seven Principles for Good Practice in Undergraduate Education ............................................ 21 


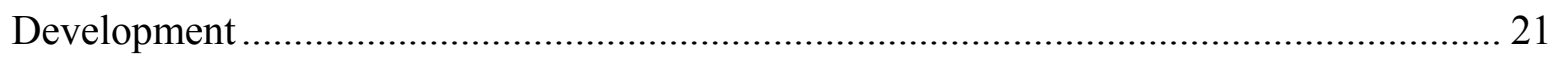

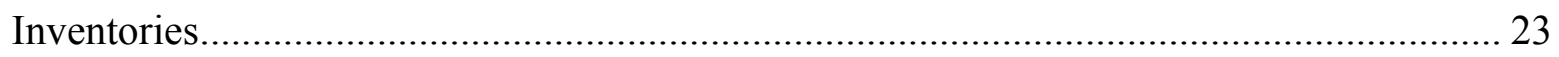

Online Instruction and Pedagogical Principles ...................................................................... 24

Technology and Learning Outcomes ................................................................................ 24

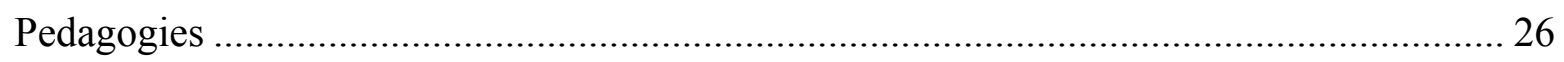

Factors That Influence Pedagogical Practice .................................................................... 29

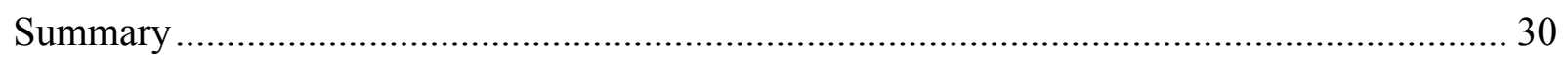

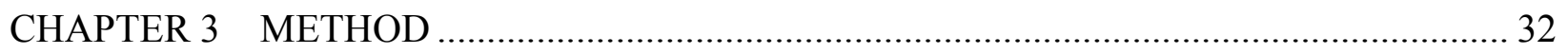

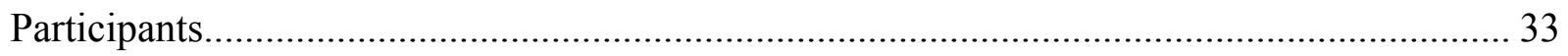

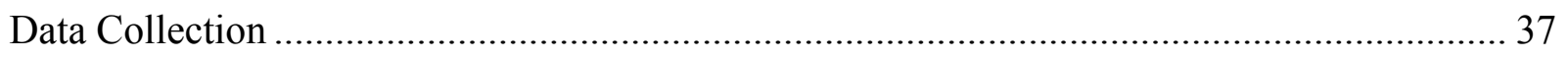

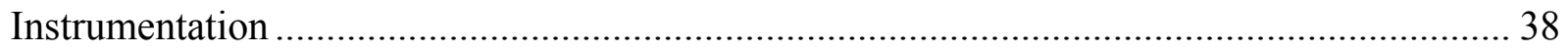

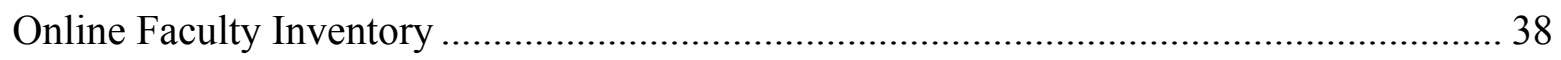

Expert Suggestions and Recommendations ................................................................... 40

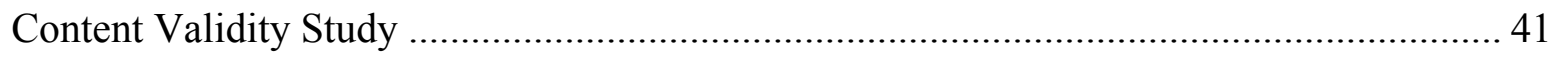

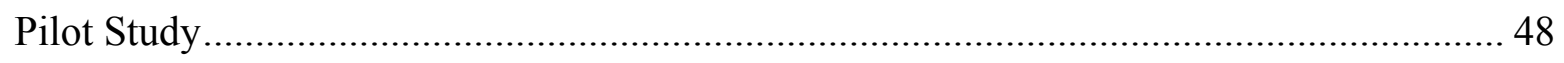

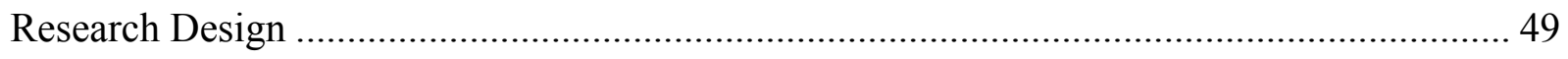

Research Question 1: Instructor Perceptions of Seven Principles Implementation............... 49

Research Question 2: Factors that Influence Seven Principles Online Implementation........ 50

Research Question 3: Relationship between Influencing Factors and the Seven Principles

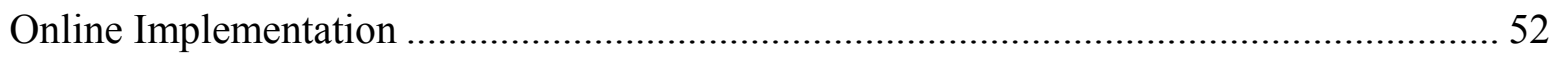

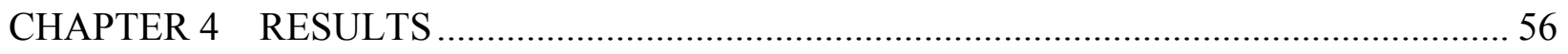

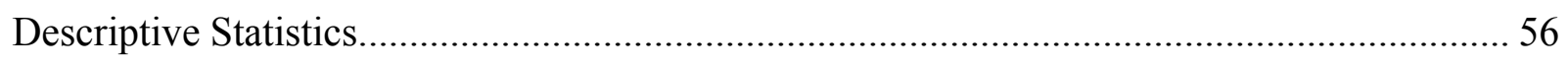

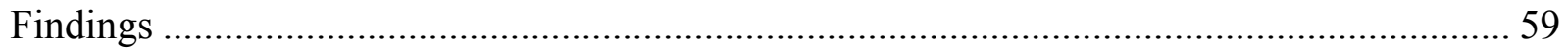




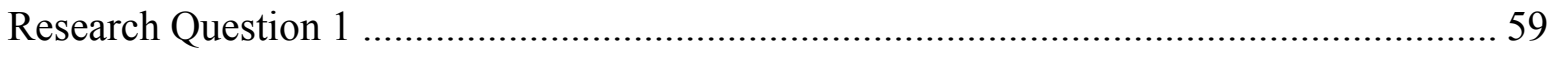

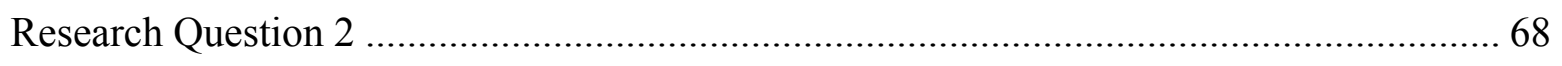

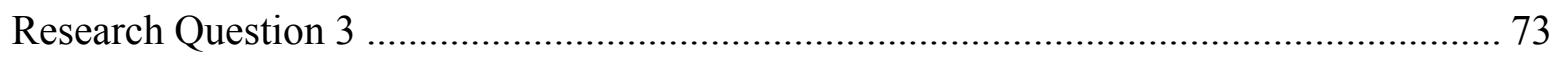

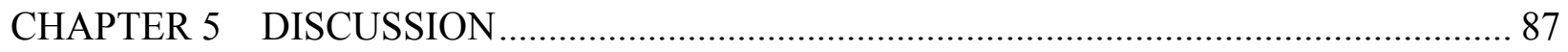

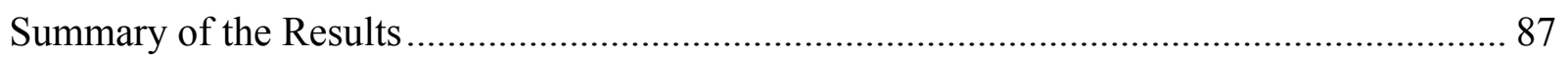

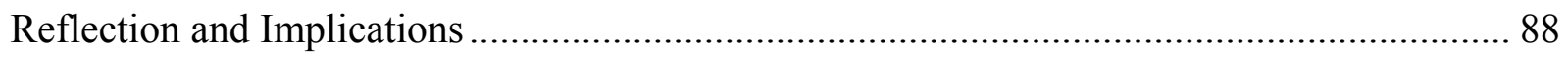

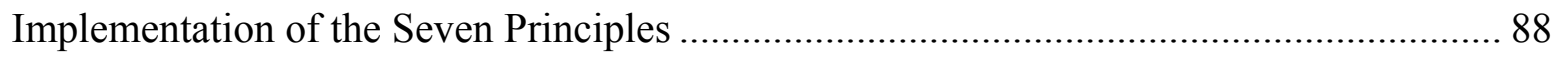

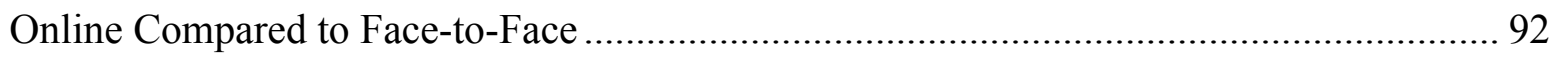

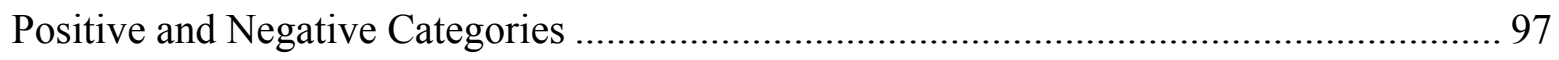

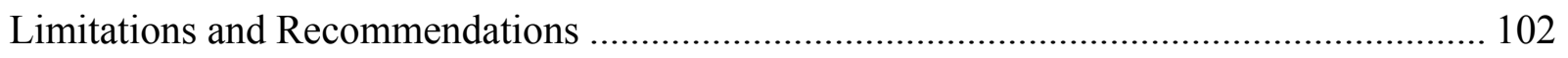

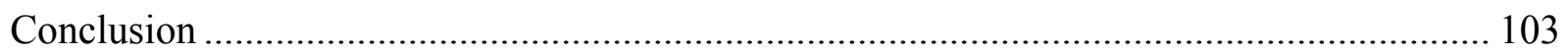

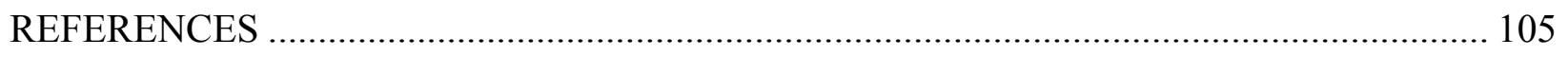

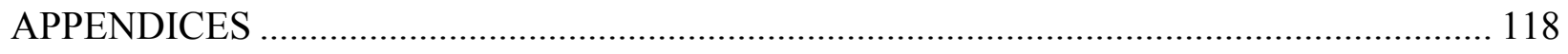

Appendix A IRB Approval for the Study …………………………............................ 119

Appendix B Course Classification............................................................................... 121

Appendix C Classes Where the Inventory Was Request to Be Completed......................... 124

Appendix D Cover Letter and E-mails to Participants ..................................................... 129

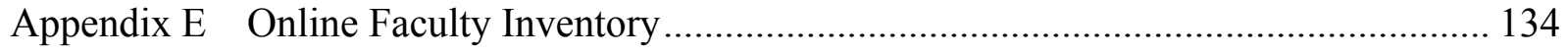

Appendix F Expert Suggestion Form …………………........................................... 141

Appendix G Cover Letter and Expert Response Form .................................................... 147

Appendix H Content Validity Study of the Instrument ..................................................... 155

Appendix I Pilot-Survey E-mail Message and Screenshot .................................................. 157

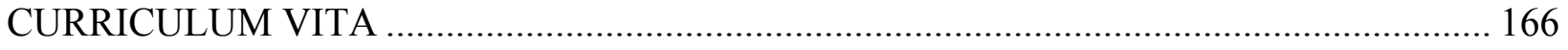




\section{LIST OF TABLES}

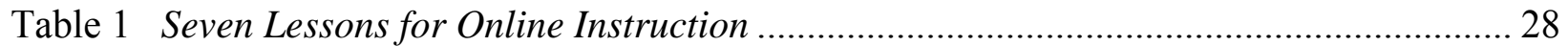

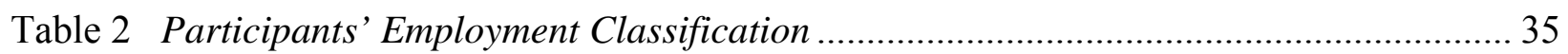

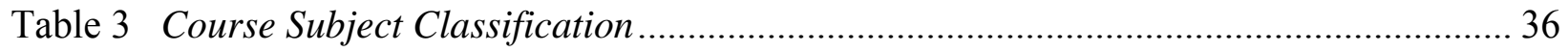

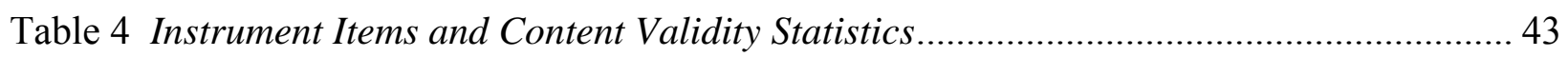

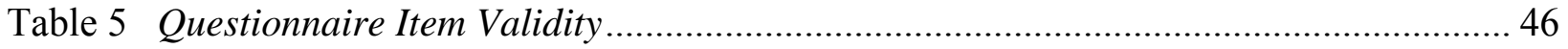

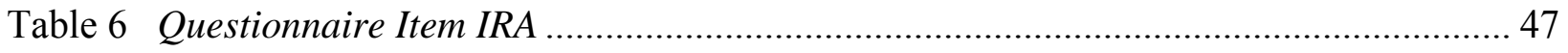

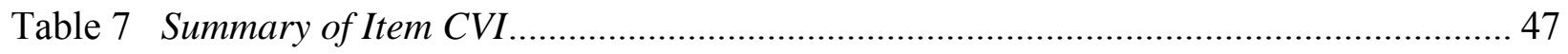

Table 8 Positive and Negative Factors ................................................................................... 51

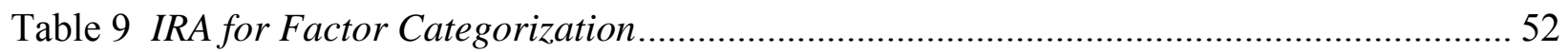

Table 10 Research Question, Data Source, and Analysis Method ............................................ 54

Table 11 Research Question and Data Source Matrix ………………......................................... 55

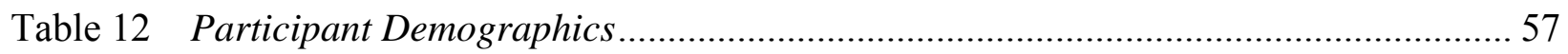

Table 13 Descriptive Statistics of the Participants and Class Size ……………........................ 58

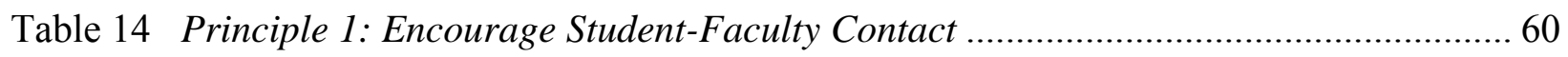

Table 15 Principle 2: Encourage Cooperation Among Students.................................................. 61

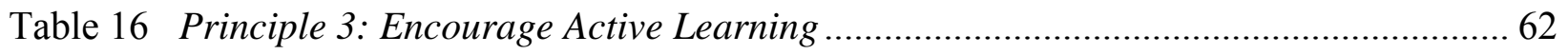

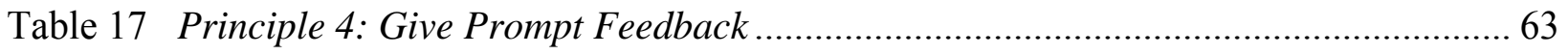

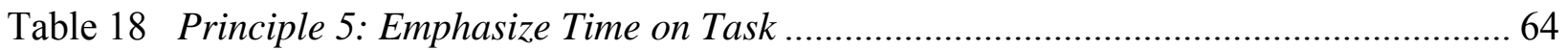

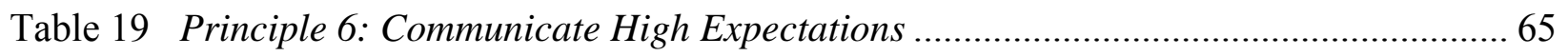

Table 20 Principle 7: Respect Diverse Talents and Ways of Learning ...................................... 66

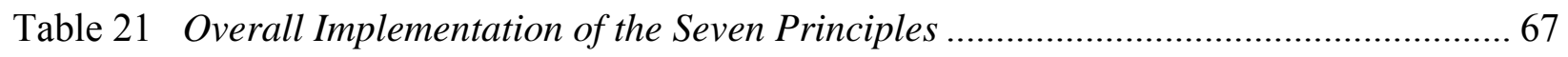

Table 22 Positive Factors for Pedagogical Practice ............................................................... 69 
Table 23 Negative Factors for Pedagogical Practice ............................................................... 70

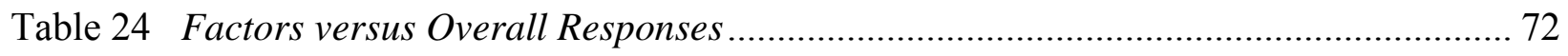

Table 25 Course Subject Area by the Seven Principles Implementation..................................... 74

Table 26 Class Size by the Seven Principles Implementation.................................................... 76

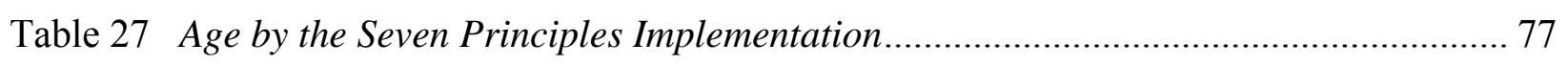

Table 28 Gender by the Seven Principles Implementation ....................................................... 78

Table 29 Teaching Experience by the Seven Principles Implementation ...................................... 80

Table 30 Online Teaching Experience by the Seven Principles Implementation ........................ 81

Table 31 On-Campus Instruction by the Seven Principles Implementation ................................ 82

Table 32 Instructor Education Level by the Seven Principles Implementation ............................ 84

Table 33 Job Classification by the Seven Principles Implementation ........................................ 85

Table 34 Online versus Face-to-Face Implementation ............................................................. 93

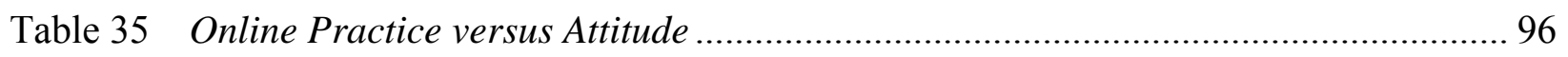




\section{LIST OF FIGURES}

Figure 1. Online (current investigation) versus face-to-face (Kausler, 2004) implementation of the Seven Principles. ............................................................................................... 94

Figure 2. Ratings for Principle 2 are low for both instructor attitude (Winegar, 2000) and practice (current investigation) 


\section{CHAPTER 1}

\section{INTRODUCTION}

The Internet as a new medium for instructional content delivery has become commonplace in the postsecondary educational settings. With the proliferation of computer and information technology, more and more colleges and universities are offering distance courses or programs for the students through the Internet. By the fall of 2003, there were more than 1.9 million students studying online in the United States, and this number was expected to reach over 2.6 million by the fall of 2004 (Allen \& Seaman, 2004). The rapid growth of online education suggests that it may become the largest source of continuing education (Keeton, 2004).

Although online distance education witnesses a rapid development, pedagogical research on Web-based instruction does not keep pace with the growth (Newlin \& Wang, 2002). We are still relatively ignorant about the most effective ways of conducting and organizing this mode of instruction. Each institution is offering its online courses in the hope of targeting traditional as well as nontraditional students and consequently expanding the enrollments. But faculty participants of online instruction, in general, start teaching online courses with little or no training about the pedagogical and technological needs in the online environment (Flowers, 2002). These instructors have inadequate knowledge of the new medium they are entering and rely heavily on their face-to-face experiences and their own pedagogy (Conrad, 2004). 
Seven Principles and Online Instruction

In 1987, Chickering and Gamson proposed "Seven Principles for Good Practice in Undergraduate Education" (hereafter referred to as Seven Principles). The Seven Principles dictate that good practice in undergraduate education:

(1) encourages student-faculty contact,

(2) encourages cooperation among students,

(3) encourages active learning,

(4) gives prompt feedback,

(5) emphasizes time on task,

(6) communicates high expectations, and

(7) respects diverse talents and ways of learning.

These seven principles are based on 50 years of higher education research on "the way teachers teach and students learn, how students work and play with one another, and how students and faculty talk to each other" (Chickering \& Gamson, 1987, p. 3). The response to the principles was immediate, enthusiastic (Gamson, 1991, 1995), and overwhelming (Chickering \& Gamson, 1999). These principles were widely used as the criteria for assessing the classroom instruction. The passionate reaction to the principles encouraged the authors of the Seven Principles to develop a self-assessment instrument for faculty members and a second instrument for campus practices and policies assessment (Chickering \& Gamson, 1999). These inventories have helped faculty members as well as their colleges and universities to examine and improve their pedagogical practices (Graham, Cagiltay, Lim, Craner, \& Duffy, 2001). 
After the creation of the Seven Principles, computer and computer network technologies emerged as major resources for teaching and learning in higher education. More recently, the use of the Internet and the World Wide Web to deliver distance instruction became ubiquitous. However, "if the power of the new technologies is to be fully realized, they should be employed in ways consistent with the Seven Principles" (Chickering \& Ehrmann, 1996, p. 3). Newlin and Wang (2002) also urged that the design and implementation of online courses should observe the "Seven Principles for Good Practice in Undergraduate Education.”

In practice, the Seven Principles are used to assess teaching practice in online distance education (Graham et al., 2001; Keeton, 2004) as well as Web-enhanced courses (Ritter \& Lemke, 2000). Graham et al. (2001) from the Center for Research on Learning and Technology, Indiana University used these principles as practical criteria to evaluate four online courses at a large Midwestern university. Their evaluation report highlighted some lessons for online instruction that correspond to the Seven Principles. Their research findings will be discussed in Chapter Two.

\section{Statement of the Problem}

Distance educators and researchers face a significant challenge in the twenty-first century. The use of computing technology and the Internet changed communication media for distance education. In most of the electronic environment, the traditional verbal, real-time, and face-to-face communications are gone. This change in media alters many of the communication environment features that people find so natural and are so accustomed to. Among these features are audibility, visibility, co-presence, instantaneity, simultaneity, and extemporaneity (Burgoon, Buller, \& Woodall, 1996). As a result of the 
change in media, online distance education differs drastically from what has been practiced for thousands of years. It is different not only from traditional, face-to-face instruction, but also from its predecessor distance education forms such as correspondence courses or distance courses via radio or television. Studies indicate that online instruction has its peculiarity of being both interactive (Garrison, Cleveland-Innes, \& Fung, 2004) and reflective (Alrajeh \& Janco, 1998; Anderson, Rourke, Garrison, \& Archer, 2001; Garrison et al., 2004). Other differences of online distance instruction from traditional face-to-face instruction include student interaction, more instructor effort, and higher student "expectations of faculty availability" (Keeton, 2004, p. 79). A teaching strategy effective for face-to-face settings may not be equally helpful or even supported at all in the digital environment (Ehrmann, 1995). However, instructors teaching online courses still largely depend on their face-to-face classroom teaching experience for the practice in this new milieu (Conrad, 2004).

Despite the great enthusiasm in Internet-based technology, online distance education is still in its early development (Terry, Owens, \& Macy, 2001; Williams, 2002). Since computer-mediated communication has been around for less than 20 years (Schrum \& Berenfeld, 1997), our knowledge of computer-mediated communication (CMC) is relatively inadequate. Online distance education which relies on this new technology has even a shorter record (Hewitt, 2003). Our limited knowledge of CMC naturally barricades our understanding of this new educational phenomenon. But at the same time we are applying this technology in education at a breakneck pace (Institute for Higher Education Policy, 2000). Ehrmann (1995) emphasized that the strategies of using technology matter most. We need to know how to take advantage of this technology and 
avoid its drawbacks when we count on it to create the educational experience (Garrison, Anderson, \& Archer, 2000). We need to be aware of the appropriateness and effectiveness of pedagogical strategies that technology can support or deliver (Ehrmann, 1995).

A review of literature reveals that there have been very few in-depth studies of the implementation of good pedagogical principles in this particular online environment. We do not know at this point to what extent the Seven Principles are implemented in online instruction. A study of online distance education needs to include the current practices of the pedagogical principles.

\section{Purpose of the Study}

The purpose of this study was to explore and describe the experience of West Virginia University faculty members who participated in the practice of online distance instruction. The study attempted (1) to explore the instructor's perception of their implementation of pedagogical principles in the online environment, (2) to determine factors that influenced their implementation of the principles, and (3) to discover the relationship between the influencing factors and the online implementation of the Seven Principles.

\section{Significance of the Study}

Higher education is a crucial national enterprise. It serves both as a means for individual development and social progress and as a means for economic growth (Oberst, 1995). This is particularly true today when the college-going stakes are higher than ever before "both in terms of costs and potential benefits to students and society" (Kuh, Kinzie, 
Schuh, Whitt, \& Associates, 2005, p. xiii). In 2001, the yearly expenses for the U.S. higher education reached $\$ 317$ billion, about $3.13 \%$ of the total gross domestic product. Approximately 15.9 million students are currently enrolled at colleges and universities, and about 1 million faculty members are employed (Snyder, Tan, \& Hoffman, 2003). As part of higher education, distance education witnessed dramatic changes during the past decade. By 2003, there were 1.9 million students studying online, and the growth rate for online enrollment continues to increase (Allen \& Seaman, 2004). It was predicted that there would be a $24.8 \%$ increase up from $19.8 \%$ in 2003 in students taking at least one online course for the year of 2004 (Allen \& Seaman, 2004).

As the trend of online instruction develops and as colleges and universities strive to meet the needs of learners by offering courses at a distance, more and more faculty members will be exposed to the possibilities of teaching outside the conventional, faceto-face environment (Flowers, 2001). Consequently, the need to explore and examine the pedagogies for the online environment has never been more imperative than it is today.

The Seven Principles is one approach to improving undergraduate education. The principles have been widely accepted and endorsed as criteria for examining teaching in traditional, face-to-face settings (Graham et al., 2001). However, the implementation of the Seven Principles in the online environment has never been examined fully.

This study is significant because results from this study can be used to create rules and regulations for effective undergraduate online instruction. The implications of the study may (a) give an insight into current online pedagogical implementation, (b) suggest modifications to online instruction practices, (c) evaluate the performance of online instruction, and (d) recommend further research regarding unanswered questions. 


\section{Research Questions}

This study examined the faculty implementation of Chickering and Gamson's (1987) Seven Principles when a course was conducted over the Internet. The following research questions were explored:

1. What are online instructors' perceptions of their implementation of the Seven Principles?

2. What factors are influencing an online instructor's level of implementation of the Seven Principles?

3. What is the relationship between the influencing factors and instructors' perception of the implementation of the Seven Principles?

\section{Definition of Terms}

Within the context of this study, following terms are used:

- Asynchronous. The term refers to the lack of synchronism or non-correspondence in time. Asynchronous communication refers to the communication when participants do not participate at the same time. E-mail and discussion board are examples of asynchronous technologies.

- Blended Course. Blended course refers to a course which combines traditional classroom instruction with online collaboration and learning. Students attend oncampus, face-to-face class on a regular but less frequent schedule. The rest of course time is used for self-directed and scheduled online collaboration and learning activities such as e-mail, threaded discussion, and chat. This course is usually facilitated by faculty using a Web-based course management system such as WebCT ${ }^{\circledR}$ 
or Blackboard ${ }^{\circledR}$. In a blended course, $30 \%$ to $79 \%$ (Allen \& Seaman, 2003) of content is delivered online. A blended course is referred to sometimes as a Web-enhanced or hybrid course.

- Chat-room. The term refers to a text-based, online, interactive, and real-time discussion. It is referred to as chat as well.

- Correspondence Course. Correspondence course refers to a course taken from a distance using written correspondence for interaction and to submit assignments.

- Discussion Board. The term refers to an asynchronous mode of discussion in which participants (both the instructor and learner) post messages that can then be read and responded to by other participants. It is known as electronic bulletin board, discussion group, discussion forum, message board, online forum, and threaded discussion as well.

- Distance Education. Distance education refers to distance instruction that takes place when an instructor and students are geographically separated, and technology is used to bridge the instructional gap.

- Distributed Education. The term refers to any technology-mediated education that is not solely face-to-face. Distributed education involves instructional activities that happen with the content expert and the learner separated by space or time, in whole or in part. It can be distance education situations where the instructor and the students are separated. It also can be conventional education where the instructor and the students meet face to face in their classroom and use technology to interact and to learn outside their face-to-face classroom meetings, like online laboratories that students can access from their dormitories. 
- E-learning. E-learning is defined as any learning that utilizes computer and computer networks for delivery, interaction, or facilitation. This would include distributed learning, distance learning (other than pure correspondence), computer-based training delivered over a network, and Web-based training. It can be synchronous, asynchronous, instructor-led, computer-based, or a combination.

- Face-to-face Instruction. The term refers to traditional class setting where the instructor and the students meet synchronously in the classroom. The instructor may use multiple media, including videotapes, and the Internet to deliver the course in person. In this dissertation, it is used interchangeably with onsite and on-campus instruction.

- Home Study. The term was historically used by private, for-profit schools to refer to correspondence study.

- Independent Study. Historically the term was used in North American universities from the mid-1960s. It was used in place of correspondence study, partly to loosen associations with for-profit correspondence schools, partly to accommodate emerging, non-text media, and partly to emphasize the greater autonomy of the student in the teacher-learner transaction.

- ISDN. ISDN stands for Integrated Service Digital Network, a technology that offers high-speed transmission of voice, data, and video through existing fixed-line infrastructure. Typical ISDN lines are either single-band or dual-band and have speeds of $64 \mathrm{kbps}$ and $128 \mathrm{kbps}$ respectively. 
- IViN. IViN is the abbreviation for Interactive Video Network. The term refers to an interactive videoconference connecting the different campuses or sites having dial-up ISDN conferencing capability. The technology is for classes or meetings.

- Off-campus. The term is a synonym for distance. It is used interchangeably in this study with off-site and distance.

- Online Instruction. The term refers to the process of instruction where the instructor and the students are geographically separated and over 80\% (Allen \& Seaman, 2003) of instructional materials are delivered through the Internet. Online instruction implies a connection to a computer system at a location distinct from the learner's personal computer (Regalbuto, 1999). Within the scope of this dissertation, the term is used to refer to Internet-mediated synchronous or asynchronous distance instruction. It is used interchangeably with the term Web-based instruction.

- Onsite Instruction. The term is used as a synonym for face-to-face or on-campus instruction.

- Real Time. The term is used as a synonym for synchronous.

- Streaming. The term refers to a data transferring technology. Streaming allows data to be transferred and processed as a steady and continuous stream over the World Wide Web. With streaming, the client browser can start displaying the multimedia data before the entire file has been transmitted.

- Synchronous. The term is defined as coinciding in time. Synchronous communication occurs simultaneously across a network of computer users. Internet chat-room is one example of synchronous communication. 
- Telecourse. Telecourse refers to a learning program that delivers instructional content through television or videotape.

- Teleconference. Teleconference refers to simultaneous two-way electronic communication between two or more sites via telephone, satellite, or computer network. Teleconference is a generic term which refers to different technologies such as audio-conference and video conference.

- Traditional Course. The term refers to conventional, in-person instruction. In a traditional course, instructional content is delivered in writing or orally.

- Web-based Instruction. The term is defined as "a hypermedia-based instructional program which utilizes the attributes and resources of the World Wide Web to create a meaningful learning environment where learning is fostered and supported" (Khan, 1997). It is a course delivered to students who do not meet in a traditional classroom; these students take the course from a remote location via the Internet. In this dissertation, the term is used interchangeably with the term online instruction.

- Web Facilitated Course. The term refers to a course which uses Internet technology to facilitate what is essentially a face-to-face course. In a Web-facilitated course, over $70 \%$ of the content (Allen \& Seaman, 2003) is delivered through the face-to-face environment. Technologies such as Web site or course management systems may be used to post syllabus and assignments. 


\section{CHAPTER 2}

\section{LITERATURE REVIEW}

This chapter presents a review of relevant literature. It is organized into four sections, summarizing the research studies in distance education, the Seven Principles, and instructional technology. A summary of this literature review is presented as the last part of the chapter.

\section{Distance Education}

Overview

Distance education refers to education when an instructor and students are separated by geographic distance (Lewis, Snow, Farris, Levin, \& Greene, 1999; Moore \& Kearsley, 2005; Willis, 1993) or by time (Lewis et al., 1999; Moore \& Kearsley, 2005) and communications technologies are used to bridge the instructional gap. The purpose of distance education is to reach out for students whose social or family obligations prevented them from attending an educational institution on a regular basis. It offers a flexible learning environment for students who are unable or unwilling to attend conventional structured classes (Tricker, Rangecroft, Long, \& Gilroy, 2001). Distance education brings the classroom from colleges and universities to homes and workplaces for the students and consequently gives them the opportunity to pursue college degrees without the inconvenience of traveling to campus (Beard \& Harper, 2002). Although distance education provides instruction in places and times that are convenient for learners, the very nature of distance education places considerable responsibility on the learner. 
Distance education includes correspondence studies, telecourse, open universities, satellite television networks, and computer networks as instruction approaches (Moore \& Kearsley, 2005). The development of Internet application in distance education in recent years facilitates the communications between the instructor and the off-campus students. Many people see the rise of distance education not only as a revolution to increase access to postsecondary education, but also as an opportunity to hasten the overall speed of higher education reform (Lewis et al., 1999).

\section{Historical Development}

Although distance education may seem like a contemporary development, it can be traced back to its origin more than a hundred years ago. Educators at different times have put to use the latest communications technologies to deliver instruction to learners at distance. Moore and Kearsley (2005) believed that distance education evolved through five generations, namely, Correspondence, Broadcast Radio and Television, Open Universities, Teleconferencing, and Internet.

The first generation started with the advent of postal delivery in the mid-1880s when Sir Issac Pitman developed the first correspondence course to teach shorthand (Matthews, 1999; Moore \& Kearsley, 2005). Within a few decades, correspondence courses and programs were available in the United Kingdom, Germany, the United States, and Japan (Matthews, 1999). In 1892, William Rainey Harper, known as the "father of correspondence instruction," established an extension division at University of Chicago to deliver university courses by mail (Kincaid, 2003; Matthews, 1999; Moore \& Kearsley, 2005). This was the world's first formal university distance education program (Moore \& Kearsley, 2005). Correspondence courses were known later as "independent study" and 
"home study" before it became recognized as part of the distance-education construct (Moore \& Kearsley, 2005). With a correspondence course, instructors sent readings, study guides, and other print materials by mail to students who gained credit for successful completion of specified assignments.

The second generation began with the use of broadcast radio and television. The first education radio station received its license in 1921. Radio, however, as an instructional delivery medium turned out to be unsuccessful (Moore \& Kearsley, 2005). In the mid-1930s, educational television started to develop.

The third generation of distance education took shape in the late 1960s and early 1970s when experiments were conducted to test the integration of different communication technologies to deliver instructional content to distance students. The idea was initiated in the Articulated Instructional Media Project and was later borrowed in setting up the Open University in Britain. The third generation of distance education represents a system approach toward distance education, and the model was used in different countries throughout the world (Moore \& Kearsley, 2005).

The fourth generation of distance education emerged in the 1980s when the primary technology used was teleconferencing. The application of audio-conferencing and video-conferencing technology changed the mode of instructor-student interaction. Different from previous forms of distance education, in which students either interacted asynchronously with the instructor via correspondence or just passively received broadcast lessons by radio or television, a student could now answer instructor's questions and the instructor could interact with the student in real time and in different locations (Moore \& Kearsley, 2005). 
The fifth generation of distance education emerged in the 1990s, with computer and computer networks as its instruction delivery channels (Moore \& Kearsley, 2005). Software packages, Internet, and World Wide Web provide students with instruction or support through synchronous or asynchronous audio, video, text, or graphic communications. Unlike its predecessor distance education mode, computer and computer networks increase the opportunities for interaction between an instructor and the student.

In the past several years, distance education experienced a great boost. In a survey conducted during the 12 months of 2000-2001 academic year, Waits and Lewis (2003) found that $89 \%$ of public 4 -year institutions and $90 \%$ of public 2 -year institutions in the United States offered distance education courses. This survey also indicated that that there were an estimated 118,100 different college-level, credit-granting distance education courses and an estimated 2,876,000 enrollments in these college-level, creditgranting distance courses offered by 2-year and 4-year postsecondary institutions.

\section{Online Education}

Internet-mediated distance education witnessed a great expansion with the arrival of World Wide Web. According to the results of 2003 Sloan Survey of Online Learning, during the fall of 2002, more than 1.6 million students took at least one online course, and over one-third of these students (about 578,000) took all of their courses online. This enrollment of at least one online course was projected to reach 1.9 million for the fall of 2003, a yearly growth rate of $19.8 \%$. This survey also indicated that over $81 \%$ of all institutions of higher education were offering at least one fully online or blended course 
(Allen \& Seaman, 2003). In addition to online courses, there are also online programs which range from associate to doctorate.

Online education has a unique feature of transcending typical time and space barriers. It facilitates flexible study with respect to time, place, and pace (Williams, 2002). Several studies indicated that online education was well received among students, and students were more likely to take distance education courses via the Internet than other means (Allen \& Seaman, 2003; Sikora \& Carroll, 2002). While online instruction has special appeal for non-traditional students, it also attracts traditional on-campus students (Carnevale, 2004).

Nevertheless, online instruction is still in its formative years of development “characterized by trial and error" (Williams, 2002, p. 263). University faculties are reluctant in the acceptance of this new phenomenon. Their attitude towards the quality of online education and its ability to equal the traditional face-to-face instruction are still conservative (Allen \& Seaman, 2003).

Jonassen (2002) criticized current online instructional activities as a simple replication of face-to-face instruction. He believed that online instruction should be innovative and focus on problem solving. Flowers (2002) criticized that online instructors often "omit critical components to consider such as cultural, motivation, and personal characteristics that affect the desire of the student to learn" (p. 24) and that "many online universities are merely placing text versions of lecture notes and rigid linear assignments online" (p. 29). Teaching is not mere presentation of information, and providing access to information is not sufficient for learning (Jonassen et al., 1997). Converting an existing course to an online environment means more than transferring what is in a filing cabinet 
to the hard-drive in a Web server. It should be redesigned with regards to pedagogical theories (Williams, 2002), and such redesigning is essential if we are to fully exploit the benefits of on-line instruction.

Jonassen et al. (1997) believed that "better models for providing a purpose, engaging learners, and structuring learners' interactions are needed" (p. 122) in order to support meaningful learning in the online environment. Moore and Kearsley (2005) argued that effective distanced instruction requires the instructor to have a thorough understanding of the "nature of interaction and how to facilitate interaction through technologically transmitted communications" (p. 140). Learner-content, learner-learner, and instructor-learner interactions (Moore, 1989) should be incorporated into online instruction.

\section{Theory of Distance Education}

Michael G. Moore proposed his theory of the pedagogy of distance education at the Ninth World Conference of the International Council for Correspondence Education in 1972 (Moore, 1972; Moore \& Kearsley, 2005). This theory combines the "perspective of distance education as a highly structured mechanical system and ... [the] perspective of a more learner-centered, interactive relationship between learner and teacher" (Moore \& Kearsley, 2005, p. 223). Since 1980, the theory became known as the theory of transactional distance (Moore, 1980, 1991).

The concept of transaction originated from the work of John Dewey (Boyd \& Apps, 1980; Moore, 1991; Moore \& Kearsley, 2005) and was further developed by Boyd and Apps (Boyd \& Apps, 1980; Moore \& Kearsley, 2005). The transactional distance 
theory defines distance education as a transaction in terms of course variables, learner variables, and instructional variables.

Transaction refers to the special nature of the relationship between the teachers and learners in the distance instruction event. Teachers and students mutually act on and affect each other to cause learning to occur for the individual learner during this event. Transaction connotes "the interplay among the environment, the individuals, and the patterns of behaviors" (Boyd \& Apps, 1980, p. 5). Transactional distance is more than simply a geographic separation of learners and instructors. It is one of understanding and perceptions, caused in part by the geographic distance (Moore, 1991). It is "a psychological space of potential misunderstandings between the behaviors of instructors and those of the learners" (Moore \& Kearsley, 2005, p. 224). Instructors, students, and educational organizations have to overcome the distance to achieve the educational objectives. Therefore, transactional distance is a "pedagogical phenomenon" (Moore \& Kearsley, 2005, p. 223).

Transactional distance is a function of two sets of crucial variables in the learnerteacher transaction. These variables are termed as dialog and structure (Moore, 1980; Moore, 1991; Moore \& Kearsley, 2005).

Dialog refers to the interaction between teacher and learner. It describes "twoway communication between student and teacher" (Moore, 1980, p. 21). Several factors determine the extent and nature of the dialog in a distance education setting. These factors include educational philosophy of the course designers, instructor and student personalities, course subject area, class size, communications media, and instruction language. Students speaking a foreign language for example, are likely to interact less 
with an instructor than their peers who share the instructor's mother tongue (Moore \& Kearsley, 2005).

Structure expresses the rigidity and flexibility of course components such as learning objectives, content themes, illustrations, exercises, projects, and tests. It depicts the extent to which these course components can "accommodate or be responsive to each learner's individual needs" (Moore, 1991, p. 4). Factors that determine the structure include philosophy of a teaching organization, teachers themselves, the academic level of the learners, content of the course, and media of communications.

The extent of dialog and the degree of structure varies from one course to another. In a course high in structure, such as a telecourse program, there is generally little dialog between instructor and learner, and transactional distance is maximized. Conversely, as dialog is increased, the existing program's structure of objectives, instructional activities, and assessment deceases to accommodate the learner's needs, thereby minimizing the transactional distance between educator and learner.

The greater the transactional distance, the more such responsibility the learner has to exercise. Learner autonomy, another concept Moore proposed in 1972, refers to the characteristic of self-direction (Moore, 1972, 1986; Moore \& Kearsley, 2005). More autonomous learners can manage greater transactional distance, requiring less course structure and course dialog for a comfortable course experience. But for less autonomous learners, a rigid course with a lot of interactive communication and guidance from the instructor would be appropriate. Moore (1991) argued that the success of distance education lies in the extent to which the institution and individual instructor are able to take into account the learners' autonomy and to provide accordingly the appropriate 
structure of leaning materials, and the appropriate quantity and quality of dialog between instructor and learner.

\section{Distance versus Face-to-Face}

Distance education differs from face-to-face instruction in several ways. Firstly, classroom teaching relies on the visual and unobtrusive cues and clues from the student. The communication between an instructor and students occurs spontaneously. An instructor and students have many opportunities for interaction, both inside and outside of class. But in distance education, an instructor has very few or even no visual cues of the students. In some situations, the cues are filtered out because of the technology used. Secondly, distance education settings impact the relationship between an instructor and the students (Willis, 1993) in that the community normally formed between an instructor and students on campus does not exist in distance education. Thirdly, in a distance education system, the interaction sometimes may be conducted by a specialist instructor who does not design or teach the course (Moore \& Kearsley, 2005).

Studies reveal that there is no significant difference between learning in distance and the face-to-face environments, regardless of the content, the educational level of the students, or the technologies involved (Merisotis \& Phipps, 1999; Russell, 1997). Nor is there any substantial difference as far as student satisfaction levels are concerned (Allen, Bourhis, Burrell, \& Mabry, 2002; Phipps \& Merisotis, 1999).

However, students are found to have a slight preference for a traditional live classroom education over a distance education (Allen et al., 2002). The dropout rates of distance education are also higher than the traditional classroom education (Carr, 2000; Lilja, 2001; Merisotis \& Phipps, 1999). Howell, Laws, and Lindsay (2004) believed that 
factors such as inconsistent methods of calculating and reporting completion, differences in student demographics, and limitations of the studies may have contributed to the high dropout rate. Lilja (2001) also argued that the higher dropout rates have "more to do with outside influences, such as job and family demands..." (p. 38).

\section{Advantages and Limitations}

The major advantages of distance education include (1) its ability of reaching out to a greater and wider student audience, (2) its flexibility and customized learning and teaching, and (3) greater interaction between instructor and students (Higher Education Research Center, 2001). But there are also concerns and negative feelings among instructors about the technology. These negative feelings generally include (1) lack of human contact, (2) more work for the instructor, (3) reliability of the technology (Higher Education Research Center, 2001), and (4) technological skills requirement for the students (Beard \& Harper, 2002).

Seven Principles for Good Practice in Undergraduate Education

The Seven Principles grew out of a summary of " 50 years of research on the way teachers teach and students learn" (Chickering \& Gamson, 1987, p. 1). One of the primary purposes of the creators of the Seven Principles was to identify instructional practices. The principles provide substantive research-based advice that can enrich our understanding and practice of higher education (Sorcinelli, 1991).

\section{Development}

After World War II, higher education in the United States experienced a dramatic expansion. The number of institutions doubled, enrollment increased, and student 
populations became more diverse. As more veterans entered colleges, public expectation as who should go to college changed (Oberst, 1995). By the mid-1960s when the postwar generation started going to college, higher education witnessed still further growth (Oberst, 1995). But the increase did not naturally lead to improvement in quality. On the contrary, the disturbing evidence about traditional practices (Gamson, 1991) pushed higher education to confront issues of quality in the 1980s (Oberst, 1995). Demands from legislators, parents, and repeated calls from within colleges and universities pushed for significant improvements in undergraduate education. Reform reports on the limited effectiveness of traditional practices plus dramatic changes in social conditions and economic requirements at the time became an impetus for change (Gamson, 1991). Seven Principles emerged as an important facet of this higher education reform movement. As a member of the Study Group on the Conditions of Excellence in American Higher Education that produced Involvement in Learning, the first in a series of reports on undergraduate education in the 1980s, Zelda Gamson was afraid that these reports would not reach the faculty members, administrators, and students to whom they were directed. She suggested that American Association for Higher Education (AAHE) sponsor the development of a statement of principles for good undergraduate education (Gamson, 1991, 1995).

Gamson and Arthur Chickering secured Johnson Foundation sponsorship and invited a small task force to meet in July 1986 "to identify key principles which characterize the practices of educationally successful undergraduate institutions ... [and to] identify research which supports those characteristics and create a draft statement of principles" (Gamson, 1991, p. 7). The task force members included scholars responsible 
for some of the most important research on the impact of the college experience (Gamson, 1991, 1995).

In 1987, the final version of the Seven Principles appeared as the lead article in the March issue of the AAHE Bulletin (Chickering \& Gamson, 1987; Gamson, 1991, 1995). These principles assert that good practice in undergraduate education (1) encourages student-faculty contact, (2) encourages cooperation among students, (3) encourages active learning, (4) gives prompt feedback, (5) emphasizes time on task, (6) communicates high expectations, and (7) respects diverse talents and ways of learning. The response to the principles was immediate and enthusiastic (Gamson, 1991, 1995).

\section{Inventories}

The passionate response to the Seven Principles encouraged the creators of the Seven Principles to develop a self-assessment instrument for faculty members and another instrument for institutions. Arthur Chickering, Zelda Gamson, and Louis Barsi obtained a small grant from the Lilly Endowment, and they started to select a small number from among hundreds of examples of the Seven Principles from different resources (Gamson, 1991, 1995). The criteria for the selection of the examples include (1) applicable to a range of disciplines, institutions, and class settings, (2) short and jargonfree, and (3) focused on behavior or practices that could be changed.

After the draft was completed, it was mailed to members of the task force and to faculty members in different types of colleges and universities. Based on the feedback, the authors revised the inventories before they were published in fall 1989 by the Johnson Foundation. Response to the inventories was again overwhelming (Gamson, 1991, 1995). 
The inventory was used for instructor self-evaluations and it was also used for empirical studies (Kausler, 2004; Winegar, 2000) as well.

The great success of the inventories led to interest in their adaptations. One such adaptation was Student Inventory, which listed student behaviors that contributed to the achievement of each of the Seven Principles (Gamson, 1991, 1995). The Student Inventory was published in 1990 (Chickering \& Ehrmann, 1996) by the Seven Principles Resource Center at Winona State University (Gamson, 1995).

Online Instruction and Pedagogical Principles

\section{Technology and Learning Outcomes}

A review of the literature presents conflicting and controversial research findings regarding the effectiveness of online distance instruction. Some research indicated the learning outcomes of online distance students are similar to, or better than, those of traditional on-campus students (Bates, 1997; Fallah \& Ubell, 2000; Keeton, 2004; Lanza \& Roselli, 1991; Lynch, 2002; Neuhauser, 2002). Other studies revealed different results. Brown and Liedholm (2002) argued that online courses represented an inferior technology compared to traditional face-to-face instruction, and online students performed significantly worse than the live students. Terry et al. (2001) joined them in providing results which suggested that students perform better in traditional courses than in virtual ones. They argued that "Internet-based instruction is not as effective" (p. 4). However, meta-studies of distance education turned to favor the distance. Shachar (2002) conducted a meta-analysis of 86 experimental and quasi-experiment studies. He discovered that in two-thirds of the cases, distance students outperformed their traditional counterparts. Allen et al. (2004), in another meta-analysis comparing the performance of 
students in distance education and students in traditional classes, found that distance education students slightly outperformed traditional students on exams and course grades. Nevertheless, other researchers believe that comparative studies of learning outcome between on-campus and off-campus students overlooked the essentials of the issue.

Richard E. Clark $(1983,1994)$ believed that technology did not influence learning and he argued that "media are mere vehicles that deliver instruction but do not influence student achievement any more than the truck that delivers our groceries causes changes in our nutrition" (1983, p. 445). The fact that media comparison studies tended to have similar results indicated that learning outcomes were independent of selection of media. Rather, it was "only the use of adequate instructional methods" (1994, p. 27) that led to understanding. He cautioned educational researchers to curb their enthusiasm for the exploration of the relationship between media and learning.

Ehrmann (1995) argued that general questions that addressed the comparative effectiveness of computer technology over traditional methods for instructional content delivery missed the point. Without adequate support for faculty to develop better understanding of teaching and learning with technology, improved learning outcomes will not result.

Russell (1997) reviewed 248 studies on distance education conducted from 1928 to1996. These studies compared student learning outcomes of on-campus instruction with those of instruction over correspondence, videotape, television, satellite, or Internet-based media. Test scores and student satisfaction were compared. All these studies indicated consistently: no significant difference was found between the comparison groups. Russell 
commented that while these comparative studies are futile, the questions remained of paramount importance about the comparative impacts of the technologies.

Robert Kozma (1991), however, challenged the view that media do not impact learning under any condition. He examined the literature on learning from book, television, computers, and multimedia and argued that all media were selectively supportive to specific types of content and pedagogies and were less supportive of others. Learning with different media had different "cognitive effects of learning" (p. 180). Hewitt (2003) discovered that CMC course interface had impact on student learning. He found that in asynchronous threaded discussion most students read messages before they posted messages, read only messages that were marked as unread, and rarely returned to messages that they had seen during a previous session. He also found that students tended to respond to messages that were less than 48 hours old. As time went by, students turned to focus their discussion on unimportant issues rather than on the instructional contents. Hewitt believed that instructional strategies and new CMC interface design are needed to keep online participants "squarely focused on the goal" (p. 44) of learning. After reviewing Hewitt's discovery, Swan (2004) argued that in Internetbased instruction, the course interface served as an intermediary between the learner and the instructional content. It could either promote or constrain student learning, and the issue of course interface deserves serious and thorough examination.

\section{Pedagogies}

Phipps and Merisotis (1999) reviewed several hundred articles, papers, and dissertations published between 1990 and 1999. They believed "the vast majority of what is written about distance learning is opinion pieces, how-to articles, and second-hand 
reports that don't include original research with subjects (students or faculty) who are being studied" (p. 13). They maintained that the question that needs to be considered is what the best way is to teach students.

Williams (2002) believed that using new technologies does not automatically guarantee learning or improve learning. She argued that "the first and most important issue ... when transferring courses to a Web-based form of delivery, is that of pedagogy" (p. 264). Scott (2002) also argued that quality online learning experiences are "critically dependent on the application of pedagogically sound theories of learning and teaching and principles of course design" (p. 19). He believed that both course developers and tutors should be pedagogically aware. However, Scott discovered in his study that faculty members at a staff-development program were more interested in practical skills such as HTML and the electronic learning environment than in course design and learning theories.

Although a given technology may support different instructional strategies (Chickering \& Ehrmann, 1996), one strategy may work better than others for a particular technology. E-mail, computer conferencing, and the World Wide Web increase opportunities for students and faculty to converse and exchange work more quickly than before, and more thoughtfully and less intimidating than when confronting each other in a classroom or faculty office (Chickering \& Ehrmann, 1996). These technologies, however, may filter away some important features of human verbal communication. Online instructors need to know the strategies that work best for the electronic environment.

In search of pedagogically sound strategies for online education, the Seven Principles are referred to from time to time. Graham et al. (2001) used the Seven 
Principles to evaluate four online courses in a large Midwestern university. They believed that using the Seven Principles as a general framework for the evaluation would provide insights into important aspects of online teaching and learning. Their study was reported in the form of seven lessons (see Table 1) corresponding to the Seven Principles.

Table 1

Seven Lessons for Online Instruction

\begin{tabular}{|c|c|c|}
\hline & Principle & Lesson \\
\hline 1. & Encourages Student-Faculty Contact & $\begin{array}{l}\text { Instructors should provide clear } \\
\text { guidelines for interaction with } \\
\text { students. }\end{array}$ \\
\hline 2. & $\begin{array}{l}\text { Encourages Cooperation Among } \\
\text { Students }\end{array}$ & $\begin{array}{l}\text { Well-designed discussion assignments } \\
\text { facilitate meaningful cooperation } \\
\text { among students. }\end{array}$ \\
\hline 3. & Encourages Active Learning & $\begin{array}{l}\text { Students should present course } \\
\text { projects. }\end{array}$ \\
\hline 4. & Gives Prompt Feedback & $\begin{array}{l}\text { Instructors need to provide two types } \\
\text { of feedback: information feedback and } \\
\text { acknowledgment feedback. }\end{array}$ \\
\hline 5 . & Emphasizes Time on Task & Online courses need deadlines. \\
\hline 6. & Communicates High Expectations & $\begin{array}{l}\text { Challenging tasks, sample cases, and } \\
\text { praise for quality work communicate } \\
\text { high expectations. }\end{array}$ \\
\hline 7. & $\begin{array}{l}\text { Respects Diverse Talents and Ways of } \\
\text { Learning }\end{array}$ & $\begin{array}{l}\text { Allowing students to choose project } \\
\text { topics incorporates diverse views into } \\
\text { online courses. }\end{array}$ \\
\hline
\end{tabular}

Flashlight Project (Ehrmann, 1995), an ongoing project run by the Teaching Learning Technology Group of the American Association for Higher Education, aims to help educators and their institutions to study and to improve educational use of technology. It has developed a set of evaluation tools that can be used to monitor the 
usefulness of technology in implementing the Seven Principles and the impacts of such changes on learning outcomes and on access (Chickering \& Ehrmann, 1996). Many of the questionnaire items are based on the Seven Principles, and they ask students about how often these principles are implemented, how often technology is used to carry out the principles, and how appropriately available technology is used for carrying them out.

Winegar (2000) conducted a research to investigate the extent to which pedagogy consistent with the Seven Principles were applied in the online environment. He found that in spite of the fact that all participating instructors teaching online courses expressed positive attitudes toward all of the principles, they did not practice them all in their instructional practice. Winegar also found online instructors had failed to implement many of the strategic practices unique to the online environment. For example, "student Web-publishing and chat guests...were rarely used" (p. 70). He believed that online instructors should be made aware of the available innovative strategies and then trained to use them appropriately.

\section{Factors That Influence Pedagogical Practice}

Miller and Miller (2000) believed that the design of an online course should take into consideration the "complex learning environment" (p. 157) of multimedia, communication opptunities, and the associative, nonlinear, and hierarchical structure of a Web site. They argued that five factors, namely, (1) theoretical orientation, (2) learning goals, (3) content, (4) learner characteristics, and (5) technological capabilities, serve as the guide to effective online instruction.

Wood (2002) found through her study that instructor beliefs are strongly related to their selections of strategies for Web-based instruction. Her findings indicated that 
teaching conceptions, teaching experience, type of technology, and instructor behaviors influenced instructors' selections of instructional strategies.

Winegar (2000) identified 6 factors as barriers to successful implementation of pedagogy consistent with the Seven Principles. The identified barriers included (1) time, (2) pedagogical skills, (3) faculty technical skills, (4) student technical skills, (5)

technical support, and (6) funding. He found time was identified as the barrier for all seven principles, and pedagogical skills were cited as barriers to fostering cooperation among students, engaging students in active learning, communicating high expectations, and accommodating diverse talents and learning styles. Student technical skills were frequently cited as barriers to the principle of encouraging student-faculty interaction, fostering student cooperation, engaging students in active learning, and emphasizing time on task.

\section{Summary}

Distance education has grown tremendously in higher education institutions in the United States and has become one of the most powerful forces influencing the direction of higher education. Distance education offers opportunities to people who are unwilling or unable to attend an educational institution on a regular basis. The nature of distance education places considerable responsibility on the student.

Distance education has different forms and has witnessed development for over a hundred years (Matthews, 1999; Moore \& Kearsley, 2005). The proliferation of computer and computer network technology brought distance education to a new era and laid the foundation for the expansion of Internet-mediated education (Moore \& Kearsley, 2005). Online instruction, being one form of distance education, enjoyed extensive development 
in recent years. Its many advantages, such as convenience and flexibility, attract both traditional and non-traditional students.

The difference between distance and conventional education lies in its different communication media for instruction and interaction. While online education enjoys great popularity, it is still a phenomenon in experimental stages, and there are problems and concerns about it. The debate is ongoing as to the role of technology in current education practice. Scholars cannot agree on whether or not educational media are a mere delivery system of instructional content. Researchers agree, however, that pedagogies are of importance.

The seven pedagogical principles for good practice in undergraduate education summarize the research on teaching and learning of half a century. These Seven Principles have been used as a framework for evaluating conventional classroom instruction ever since their creation in 1987. In order to make full use of the Internet technology for distance education, we should employ the technologies in ways consistent with these pedagogical principles. 


\section{CHAPTER 3}

\section{METHOD}

This study sought to evaluate the implementation of the Seven Principles in the online environment. It investigated instructors' perception of their implementation of the Seven Principles and explored the major factors that enhanced or barricaded their implementation when instruction was delivered primarily through the Internet. The study also attempted to identify the relationship between some of the influencing factors and instructors' perception of their implementation of the Seven Principles. A survey design was used to probe online instructors' perception of their practice. The research questions this study sought to answer were:

1. What are online instructors' perceptions of their implementation of the Seven Principles?

2. What factors are influencing an online instructor's level of implementation of the Seven Principles?

3. What is the relationship between the influencing factors and instructors' perception of the implementation of the Seven Principles?

This chapter describes the design and procedures used for the study. The following sections describe the participants of the study, the data collection method, and the instrument-design process. The final part of this chapter discusses the research design. 


\section{Participants}

The population of the study was defined as the faculty members who taught undergraduate online courses at West Virginia University. These were distance courses for undergraduate students with more than $50 \%$ of the instruction being delivered through the Internet. The participants of this study were instructors who taught undergraduate online courses during spring, summer, and/or fall semesters of 2005 at West Virginia University, Potomac State College of West Virginia University, and West Virginia University at Parkersburg.

The participants were identified through the Office of Admissions and Records. After an internal data request was filed through the office, a query was made into one of the university databases, which returned 346 records about undergraduate online distance courses. Each record included 16 fields: CRN (course request number), subject, course number, section number, course title, semesters when the course was offered, SLI Label (Schedule Listing Index), primary delivery method, instructor first name, middle initial, last name, instructor e-mail address, course levels (undergraduate, graduate, and professional), and primary instructor indicator (yes or no).

Microsoft ${ }^{\circledR}$ Access was used to organize and analyze the data obtained from the university database. Relevant information fields such as second e-mail address, mailing address, job title, and job classification were added to each of the records. Different resources were consulted to ensure that contact information in the database was accurate and up-to-date. The resources referred to included (1) West Virginia University Directory 2004-2005, (2) WVU On-line Directory, (3) West Virginia University GroupWise ${ }^{\circledR}$ Email Address Book, and (4) Potomac State College of WVU Online Faculty Directory. In 
addition, Google ${ }^{\mathrm{TM}}$ search engine was used to locate the instructor's personal Web site or course syllabus. For the records where the instructor was marked as "Census Staff" or "Staff," the researcher contacted the Office of Admissions and Records in person and through e-mail to track who were teaching these classes. He also consulted the Schedule of Courses of 2005 and WVU online course catalog and sent e-mail to the concerned departments in his attempt to track down the instructors who were teaching these courses.

A total of 123 instructors were initially identified. Of these 123 instructors, only 113 were actually teaching the courses. The remaining 10 instructors were assistants to the primary instructors. They did not interact with the distance students directly. As one of the assistants stated in his e-mail to the researcher, "I work with the coordinator of the online course. So I attend the trainings to gain access to WebCT Vista as an instructor to help her keep the course organized. I do not actually correspond with the students; my work is almost completely 'behind the scenes' " (SMY3282, personal communication, September 8, 2005). Another six instructors e-mailed or called the researcher to inform him that they were not teaching an online course because of "last-minute" (Thumm, G., personal communication, September 7, 2005) changes, or their names were just a "place holder" (Torsney, C., personal communication, September 7, 2005) in the system, or it was just an error. There were a total of 107 instructors who were finally identified as teaching 282 sections of 132 undergraduate online classes in 2005.

These online instructors consisted of faculty (tenured, tenured track, clinical track, librarian track, and non-tenure track), staff (classified and non-classified), and graduate assistants. There were 50 non-tenure track faculty (46.73\%), 31 tenure-track faculty (28.97\%), 12 graduate assistants (11.21\%), 6 non-classified staff (5.61\%), 4 librarians 
(3.74\%), and 2 classified staff (1.87\%). The researcher failed to identify the job title or classification for 2 instructors (1.87\%). Table 2 presents the number and percentage of each category. Guidelines for protection of human participants were followed, and IRB Human Participants Protection permission was obtained (Appendix A) before the instructors were invited to participate.

Table 2

\begin{tabular}{lrr}
\multicolumn{1}{c}{ Participants' Employment Classification } & \\
\hline \multicolumn{1}{c}{ Classification } & $n$ & \multicolumn{1}{c}{$\%$} \\
\hline Faculty Non-Tenure Track & 50 & 46.73 \\
Faculty Tenure Track & 31 & 28.97 \\
Students & 12 & 11.21 \\
Non-classified Staff & 6 & 5.61 \\
Librarian & 4 & 3.74 \\
Classified Staff & 2 & 1.87 \\
Unknown & 2 & 1.87 \\
\hline & 107 & 100.00
\end{tabular}

The participants were divided into two groups (a) Humanities and (b) Science \& Technology based on the discipline of the course they were teaching. The researcher relied on standard library classification methods (Taylor, 2000) for the grouping scheme (see Appendix B for detail). Table 3 lists the course subjects of all WVU undergraduate online courses under these two Subject Areas. A list of all the undergraduate online courses for which the instructor was requested to participate in the study is included in Appendix C. 
Table 3

Course Subject Classification

Subject Area

WVU Course

\begin{tabular}{|c|c|}
\hline \multirow[t]{25}{*}{ Humanities } & ADV (Advertising)* \\
\hline & AGEE (Agricultural / Envir. Ed.)* \\
\hline & BUSA (Business Administration) \\
\hline & CDFS (Child Development/ Family Studies)* \\
\hline & CJ (Criminal Justice)* \\
\hline & COMM (Communication Studies)* \\
\hline & ECON (Economics)* \\
\hline & ENGL (English)* \\
\hline & ENTR (Entrepreneurship) \\
\hline & F\&CS (Family \& Consumer Sciences)* \\
\hline & HIST (History) \\
\hline & HN\&F (Human Nutrition and Foods)* \\
\hline & JRL (Journalism)* \\
\hline & MDS (Multidisciplinary Studies)* \\
\hline & MILS (Military Science) \\
\hline & MKTG (Marketing) \\
\hline & N-E (News Editorial)* \\
\hline & ORIN (Orientation) \\
\hline & PHIL (Philosophy) \\
\hline & POLS (Political Science)* \\
\hline & PR (Public Relation)* \\
\hline & PSYC (Psychology)* \\
\hline & SOCA (Sociology and Anthropology)* \\
\hline & SOWA (Social Work) \\
\hline & SPA (Speech Pathology and Audiology) \\
\hline \multirow[t]{6}{*}{ Science \& Technology } & A\&VS (Animal and veterinary Science)* \\
\hline & CHEM (Chemistry) \\
\hline & CS (Computer Science)* \\
\hline & EXPH (Exercise Physiology) \\
\hline & GEOL (Geology) \\
\hline & MATH (Mathematics)* \\
\hline
\end{tabular}




\author{
MTEC (Medical Technology)* \\ PHYS (Physics)* \\ PLSC (Plant Science)* \\ STAT (Statistics) \\ CHPR (Community Health Promotion) \\ DTHY (Dental Hygiene) \\ NBAN (Neurobiology and anatomy)* \\ NSG (Nursing)* \\ OTH (Occupational Therapy)* \\ PCOL (Pharmacology and Toxicology)
}

Note. An asterisk * indicates the course where the inventory was completed.

\title{
Data Collection
}

An online survey was administered in September 2005. One of the potential problems for a questionnaire survey was its low response rate (Berdie, Anderson, \& Niebuhr, 1986). In order to obtain a higher response rate, both ordinary mail and e-mail were sent to invite the instructors to participate. A package was sent to the participants on September 6, 2005 through campus mail to their offices on the Morgantown campus. Postal service was used to send the package to participants from Potomac State College of WVU or WVU at Parkersburg. Postal service also was used for participants whose campus mail numbers were not found. The package contained a cover letter and a copy of the IRB approval. This invitation assured participants confidentiality, and it provided the participant with the URL of the Web-based survey.

About a week after the package was sent out, follow-up strategy (Berdie et al., 1986) was employed by sending e-mail reminders to all the 100 non-respondents. This email message urged the participants to complete the survey. Mail Merge function of 
Microsoft ${ }^{\circledR}$ Word was used to generate and batch-process all the e-mails. A total of 174 reminder e-mails were sent to the non-respondents on September 15, 2005. Some of the non-respondents received two identical e-mails if two different e-mail addresses were identified for a participant. Ten days later, another e-mail message was sent out to the 47 identified non-respondents. Delay mail delivery function of Novell ${ }^{\circledR}$ GroupWise ${ }^{\circledR}$ was used to send all the mail at 8:00 am, September 25, 2005, so that the recipients were able to receive the mail on Sunday morning. Data collection concluded on September 30, 2005. After the conclusion of data collection, on October 5, 2005, ten e-mail messages were sent to participants to clarify the responses from some participants.

In all, invitations were sent to 107 legitimate participants, and responses were received from 49 instructors. The response rate was 45.79 percent. A copy of the cover letter and the e-mail messages are included in Appendix D.

\section{Instrumentation}

\section{Online Faculty Inventory}

Instrument development has a direct impact upon outcomes of a study (Davis, 1992). The instrument used for the study was entitled "Online Faculty Inventory.” The items in the survey questionnaire asked instructors to report their implementation of pedagogical principles in their online instruction. The questionnaire consisted of two sections: Demographics and Pedagogical Principles.

The Demographics section asked the participants to supply demographic information about the participant and basic information about the class he or she was teaching. It included course subject and course number, instructor classroom teaching experience, online teaching experience, student on-campus participation, instructor age, 
gender, highest degree obtained, instructor job classification, class size, and instruction delivery technology.

The Pedagogical Principles section was made up of seven parts, each of which dealt with one of the Seven Principles. This section was designed to explore the instructor's perception of their implementation of pedagogical principles. In every part of the Pedagogical Principles section, there were 5 questionnaire statements and 2 openended questions. The questionnaire statement in this section was rated on a 5-point Likert scale in which the choices were $1=$ Never, $2=$ Rarely, $3=$ Occasionally, $4=$ Often, $5=$ Very Often. At the end of each of the seven parts were two open-ended questions. The first open-ended question asked the participant to indicate the factors that promoted the implementation of that particular one of the Seven Principles. The second open-ended question asked the participant to indicate the factors that hindered the implementation of the same pedagogical principle. These open-ended questions were asked seven times, one for each of the Seven Principles.

The questionnaire statements were based on Faculty Inventory (Chickering, Gamson, \& Barsi, 1989). Since the original inventory was intended to assess traditional face-to-face instruction, modification to the inventory was made so that the items were meaningful for online instruction. Several major procedures were involved in the development of the inventory. These procedures included (a) selecting some items verbatim as written in the Chickering et al. (1989) instrument, (b) rewriting items from Chickering et al. (1989) to make them more applicable to undergraduate online education, (c) eliciting expert suggestions and comments to the first draft of the inventory, (d) rewriting or adding items based on expert suggestions, and (e) assessing content validity 
of each of the items in the resulting draft instrument. After incorporation of expert suggestions, there were 64 items in the draft, as is shown in Expert Response Form in Appendix G. Only 35 items were finally selected in Online Faculty Inventory. As may be noted, there are five items for each of the Seven Principles in the Online Faculty Inventory. These items represent content validity in which there is (a) fair sampling of items from the domains of instruction, and (b) expert judgment regarding the items that can be used to assess each principle. A complete copy of Online Faculty Inventory is included in Appendix E, in which items borrowed directly from Faculty Inventory (Chickering et al., 1989) were shaded, whereas no such distinction was made in the inventory given to the participants.

\section{Expert Suggestions and Recommendations}

After the instrument was initially drafted inputs were elicited from experts who had online teaching experience, research experience in instructional technology, or research experience in the area of the Seven Principles. Each member of this group received, through e-mail, a copy of the draft inventory and an Expert Suggestion Form. In the Expert Suggestion Form, questionnaire items were listed in two columns. The original 70 items from Chickering et al. (1989) were listed on the left and adopted and adapted items for Online Faculty Inventory were listed on the right (see Appendix F). This format was used to provide a clear picture of which item had been modified or removed and which item was borrowed without any modifications.

The first e-mail was sent out on July 12, 2005, and the latest response from the experts was received on August 4, 2005. Initial feedback responses from the experts were used to update the Expert Suggestion Form before it was sent out to other experts. 
Comments and suggestions from the experts were incorporated into the draft Online Faculty Inventory.

Major changes in this process included rephrasing items and adding items that had been previously removed from the Chickering et al. (1989) inventory. In Expert Response Form (Appendix G), items 2-1, 2-4, 2-7, 3-7, 3-9, 3-10, 4-7, 4-8, 4-9, 5-5, 6-2, 6-7, 6-9, and 7-6 were put back after the researcher received suggestions and comments from the experts. Item 2-1 was changed back to "I ask students to tell each other about their interests and background" from the previously modified version "I arrange special chat room sessions for students to get to know each other." Item 2-9 was modified and then added. It was revised from "I encourage students to join at least one campus organization" to "I encourage students to be involved in their professional organizations." In item 4-1 "online activities" was used to replace "classroom exercises and problems." In item 6-8, "I publish student work through course Web site" was changed into "I publish exemplary work through course Web site."

Other suggestions addressed inventory instruction, font style, and deletion of items. All comments and suggestions were seriously considered and incorporated into the draft inventory when appropriate. No item was deleted at this time.

\section{Content Validity Study}

Content validity is a crucial factor in instrument construction (Grant \& Davis, 1997; Lynn, 1986). Content validity was necessary because Online Faculty Inventory was modified from the original and the instructional environment for use of this inventory varied from its original environment, content validity was studied. Content validity was assessed by (1) selecting an Expert Panel, (2) submitting the draft instrument to the 
Expert Panel, (3) having the Expert Panel rate each item on a 1 to 4 scale for content validity related to the Seven Principle for online education, and (4) selecting the five highest-rated items for each the Seven Principles.

The expert panel was selected based on the professional expertise and experience of the experts. The panel consisted of content experts and lay experts (Rubio, BergWeger, Tebb, Lee, \& Rauch, 2003). The content experts were professionals who published or worked in the area of instructional technology, online instruction, and teaching strategies. Lay experts were individuals for whom application of online instruction in their own field (e.g., English or Math) was of interest. They spend considerate amount of time teaching courses over the Internet. The number of experts for the panel followed what was suggested in literature. According to Lynn (1986), an expert panel should consist of at least three members. Rubio et al. (2003) recommended three members for each of the two groups (content experts and lay experts). A cover letter and response form were sent to the expert panel members through e-mail or face-to-face arrangement in early August of 2005. In mid August, an e-mail reminder was sent to the non-respondents, which urged the expert panel members to complete the Expert Response Form and return it to the researcher. Before the expert evaluation phase ended in late August, the researcher visited in person the non-respondent experts with a copy of Expert Response Form. A total of 12 Expert Response Forms were sent out, and 7 were collected ( 4 for the content experts, and 3 for the lay experts).

Expert Response Form contained a brief instruction and all the draft questionnaire questions. The panel members were requested to indicate the appropriateness of the items for measuring the pedagogical principle as it was used for online distance instruction on a 
4 point Likert-type scale. Number 1 indicated the item was "not usable," and number 4 indicated the item was "clear and representative of the principle." A copy of the cover letter and response form are included in Appendix G. After the Expert Response Forms were collected, mean, Inter-Rater Agreement (IRA), and Content Validity Index (CVI) were calculated for each item and for the entire scale. Shown in Table 4 are the 35 items used in the instrument along with the content validity statistics. Calculations used for Mean, IRA, and CVI are described after Table 4.

Table 4

Instrument Items and Content Validity Statistics

Items $\quad M^{\mathrm{a}} \operatorname{IRA}^{\mathrm{b}} C V I^{\mathrm{c}}$

1. Encourage Student-Faculty Contact

I advise my students about career opportunities in their major field.

$3.29 \quad 0.71 \quad 0.71$

I share my past experiences, attitudes, and values with

$3.86 \quad 1.00 \quad 1.00$ students.

I know my students by name by the end of the first two $\quad 3.86 \quad 1.00 \quad 1.00$ weeks of the term.

I serve as an informal advisor to students via e-mail. $\quad 3.43 \quad 0.86 \quad 0.86$

I invite or take my students to attend professional $\quad 3.71 \quad 0.86 \quad 0.86$ meetings or other events in my field.

2. Encourage Cooperation Among Students

I encourage my students to prepare together for classes or $\quad \begin{array}{llll}4.00 & 1.00 & 1.00\end{array}$ exams.

$\begin{array}{llll}\text { I encourage students to do projects together. } & 4.00 & 1.00 & 1.00\end{array}$

$\begin{array}{lllll}\text { I ask my students to evaluate each other's work. } & 3.71 & 0.86 & 0.86\end{array}$

$\begin{array}{lllll}\text { I ask my students to discuss key concepts with other } & 3.71 & 0.86 & 0.86\end{array}$ students whose backgrounds and viewpoints are different from their own.

I create "learning communities," study groups, or project $\quad 3.86 \quad 1.00 \quad 1.00$ teams within my courses. 
3. Encourage Active Learning

I ask my students to relate outside events or activities to the subjects covered in my courses.

I encourage students to challenge my ideas, the ideas of $\quad \begin{array}{llll}4.00 & 1.00 & 1.00\end{array}$ other students, or those presented in readings or other course materials.

I give my students concrete, real-life situations to analyze.

I encourage my students to suggest new readings, research projects, field trips, or other course activities.

$\begin{array}{lll}4.00 & 1.00 & 1.00\end{array}$

I carry out research projects with my students.

$\begin{array}{lll}4.00 & 1.00 & 1.00\end{array}$

$\begin{array}{lll}3.57 & 0.86 & 0.86\end{array}$

$\begin{array}{lll}3.71 & 0.86 & 0.86\end{array}$

4. Give Prompt Feedback

$\begin{array}{llll}\text { I prepare online activities which give students immediate } & 3.86 & 1.00 & 1.00\end{array}$ feedback on how well they do.

$\begin{array}{llll}\text { I return examinations and papers within a week. } & 3.71 & 0.86 & 0.86\end{array}$

I give students detailed evaluations of their work early in $\begin{array}{rrr}3.86 & 1.00 & 1.00\end{array}$ the term.

I ask my students to schedule conferences (phone calls, $\quad 3.86 \quad 1.00 \quad 1.00$ chat room, or on-campus) with me to discuss their progress.

I give my students written comments on their strengths and weaknesses on exams and papers.

$3.71 \quad 0.86 \quad 0.86$

5. Emphasize Time on Task

I expect my students to complete their assignments promptly.

I clearly communicate to my students the minimum amount of time they should spend preparing for classes.

I underscore the importance of regular work, steady application, sound self-pacing, and scheduling.

I contact students who fall behind to discuss their study habits, schedules, and other commitments.

If students miss my classes, I require them to make up lost work.

$\begin{array}{lll}3.57 & 0.86 & 0.86\end{array}$

$\begin{array}{lll}3.57 & 0.86 & 0.86\end{array}$

$3.71 \quad 0.86 \quad 0.86$

$3.86 \quad 1.00 \quad 1.00$

$3.29 \quad 0.86 \quad 0.86$

6. Communicate High Expectations

I tell students that I expect them to work hard in my classes.

$3.71 \quad 0.86 \quad 0.86$

I emphasize the importance of holding high standards for

$\begin{array}{lll}4.00 & 1.00 & 1.00\end{array}$ academic achievement.

I make clear my expectations in writing at the beginning

$\begin{array}{lll}3.86 & 1.00 & 1.00\end{array}$ 
of the course.

I help students set challenging goals for their own learning.

$\begin{array}{lll}4.00 & 1.00 & 1.00\end{array}$

I explain to students what will happen if they do not

$3.29 \quad 0.86 \quad 0.86$ complete their work on me.

7. Respect Diverse Talents and Ways of Learning

I encourage students to speak up when they don't

$\begin{array}{lll}3.43 & 0.86 & 0.86\end{array}$ understand.

I use diverse teaching activities to address a broad

$\begin{array}{lll}3.86 & 1.00 & 1.00\end{array}$ spectrum of students.

I select readings and design activities related to the background of my students.

$3.57 \quad 0.86 \quad 0.86$

I integrate new knowledge about women and other under-

$3.29 \quad 0.71 \quad 0.71$ represented populations into my courses.

I try to find out about my students' learning styles, $4.00 \quad 1.00 \quad 1.00$ interests or backgrounds at the beginning of each course.

Note. ${ }^{\mathrm{a}} M=$ Mean. The score stands for $1=$ item not usable, $2=$ item may be usable with major work on clarity and representativeness, $3=$ item may be usable with work on either clarity or representativeness, $4=$ item is clear and representative of the principle. ${ }^{\mathrm{b}} I R A=$ Inter-Rater Agreement. ${ }^{\mathrm{c}} \mathrm{CVI}=\mathrm{Content}$ Validity Index.

The Mean of an item was the arithmetic average of the scores given by the seven experts. The highest possible mean was 4 , which indicated unanimous agreement among the panel members that the item was "clear and representative of the principle." The lowest possible was 1 , which indicated unanimous agreement that the item was "not useable." As is indicated in Table 4, the mean for individual items in the Faculty Online Inventory ranged from 3.29 to 4.00 . Four items (11.43\%) received a mean of 3.29, two items $(5.71 \%)$ received a mean of 3.43 , four items $(11.43 \%)$ received a mean of 3.59 , and the rest of the items $(n=25,71.43 \%)$ received a mean score of 3.71 and over. Table 5 gives a summary of the means of the questionnaire items. The mean for the whole scale was the arithmetic mean of the 35 items, which was 3.73 . Thus, all 35 items were rated 
by the seven experts with a mean of 3.29 or higher on the 4-point scale, indicating that all 35 items were all in the usable range.

\section{Table 5}

Questionnaire Item Validity

\begin{tabular}{ccc}
\hline Mean & Number of Items & $\%$ \\
\hline 3.29 & 4 & 11.43 \\
3.43 & 2 & 5.71 \\
3.57 & 4 & 11.43 \\
3.71 & 8 & 22.86 \\
3.86 & 9 & 25.71 \\
4.00 & 8 & 22.86 \\
\hline & 35 & 100.00
\end{tabular}

The four-point scale in the Expert Response From was dichotomized (Davis, 1992; Lynn, 1986; Rubio et al., 2003) to determine IRA for an item, combining values one and two and values three and four. Then, the proportion of the number of experts who agreed out of the total number of experts (seven) in the panel (Lynn, 1986) was calculated. Since IRA indicated the reliability of expert rating (Rubio et al., 2003), items with a low IRA were removed from the instrument. The resulting was items with relatively high IRA scores. As Table 6 indicates, $94.29 \%(n=33)$ of the items gained an IRA of .86 or over. The IRA for the scale was determined by the proportion of items with .80 reliability (i.e., $\operatorname{IRA}=.80$ ) in the inventory (Rubio et al., 2003). For Online Faculty Inventory, the scale IRA reached .94 , or $94 \%$ of the 35 items in the inventory had an item IRA of .80 (see Appendix H). 
Table 6

Questionnaire Item IRA

\begin{tabular}{ccc}
\hline IRA Score & Number of Item & $\%$ \\
\hline 0.71 & 2 & 5.71 \\
0.86 & 16 & 45.71 \\
1.00 & 17 & 48.57 \\
\hline & 35 & 99.99
\end{tabular}

Content Validity Index (CVI) of an item indicated the proportion of experts who rated the item as content valid (Lynn, 1986; Rubio et al., 2003). CVI for each item was determined by the proportion of experts who gave the item a rating of 3 or 4 . An item with low CVI scoring signified poor content validity, and was consequently deleted from the instrument. A total of $94.29 \%(n=33)$ of the questionnaire items obtained a CVI of .86 or over. Table 7 presents a summary of the content validity of the scale. The CVI for the entire inventory was calculated by the proportion of total items judged content valid (Davis, 1992; Grant \& Davis, 1997; Lynn, 1986). The CVI for Online Faculty Inventory was .92 or $92 \%$.

Table 7

Summary of Item CVI

\begin{tabular}{ccc}
\hline CVI Score & Number of Items & $\%$ \\
\hline 0.71 & 2 & 5.71 \\
0.86 & 16 & 45.71 \\
1.00 & 17 & 48.57 \\
\hline & 35 & 99.99
\end{tabular}


As stated previously, Online Faculty Inventory had a Mean of 3.73, a scale IRA of .94, and a scale CVI of .92. According to Davis (1992), a CVI of $80 \%$ or better agreement among panel members would be acceptable. A complete listing of Mean, IRA, and CVI for each individual item and the scale is included in Appendix $\mathrm{H}$. The formulae used for calculation are shown as footnotes.

\section{Pilot Study}

A pilot study was conducted by the end of August to further assess the feasibility of the survey and survey questions. The purpose of this piloting was to make sure that participants would respond in accord with instructions, to discover and decide how to handle unanticipated problems, and to check the adequacy of the survey Web site and the program that supported the online survey. On August 17, 2005, a cover letter for the pilot study was sent to 18 online instructors who taught graduate level online courses in the year of 2005. They were instructors from 11 different programs and were teaching 33 different sections of online graduate courses. They were deeply involved in online distance instruction. Some of them were teaching different online classes in one semester; others were offering online courses twice a year. Measures were taken to make sure that these faculty members were not to be in the sample of the study. The e-mail message and the screenshot of the pilot survey are presented in Appendix I.

The pilot study indicated that the design of the research was appropriate, and the Web site was functioning as expected. A bug in the program was detected that rendered participants using Macintosh with Netscape browser unable to submit their inventory. Comments and suggestions from the participants in the pilot study were incorporated in the implementation of the final draft. In this pilot survey, some participants were not clear 
about what was asked about "technology." In the final survey, "Instruction Delivery Technology" was used instead. The software problem was fixed before the survey was finally launched.

\section{Research Design}

This study used a survey design to investigate instructor perceptions of their implementation of the Seven Principles, major factors that influenced their implementations, and the relationship between the influencing factors and the perceived implementation of the Seven Principles. The independent variables examined in this study were course subject, classroom teaching experience, online teaching experience, student on-campus participation, instructor age, gender, highest degree obtained, instructor job classification, and class size. The dependent variables in this study were instructor self-reported implementation of pedagogical principles. These variables were used to determine the relationship between the influencing factors and the implementation of the Seven Principles.

\section{Research Question 1: Instructor Perceptions of Seven Principles Implementation}

The data source for Research Question 1 was the Likert scale ratings. The Likert scale for each of the rated items ranged from 1 (Never) to 5 (Very Often). Each rated item generated a mean across all the participants. This mean indicated the implementation of the strategy stated by the item. A total score was generated for each of the seven pedagogical principles. This score indicated the implementation of one of the Seven Principles in the online environment. Descriptive means $(M)$ and Standard Deviations $(S D)$ were used for analysis. As an example of the approach to answering Research 
Question 1, Online Instructor's Perception of Their Implementation of the Seven Principles, means and standard deviations for each individual item and for the Pedagogical Principle (Student-Faculty Contact) were used.

\section{Research Question 2: Factors that Influence Seven Principles Online Implementation}

The data source for Research Question 2 was the two open-ended questions, which elicited the participants to report the major factors that promoted or obstructed their implementation of the principle concerned. The positive and negative statements were categorized for each of the seven pedagogical principles separately. Because of the scoring judgments involved in categorizing responses to open-ended questions, a second scorer was invited to categorize the responses (blind to the researcher's scoring). Interscorer reliability was tested to measure the agreement between the scorers using the formula:

$$
\text { Percentage of Agreement }=\frac{\text { Agreements }}{\text { Agreements }+ \text { Disagreements }} \times 100 \text {. }
$$

The coding process included four major steps (1) reviewing all responses from the 47 participants, (2) highlighting words or phrases with high frequencies, (3) setting up draft categories, and (4) adjusting the category list. Table 8 presents a list of all the categories for both positive and negative factors. 
Table 8

Positive and Negative Factors

\begin{tabular}{ll}
\hline \multicolumn{1}{c}{ Positive Factors } & \multicolumn{1}{c}{ Negative Factors } \\
\hline Accessibility \& Availability & Class Size \\
Challenges \& Rules & Content \& Design \\
Communications & Lack of Student Involvement \\
Content Materials & Motivation \& Negligence \\
Instructional Activities & Student Negligence \\
Instructional Strategies & Technical Difficulties \\
Personal Contact & Technology \\
Rules \& Encouragement & Technology Competence \\
Syllabus \& Feedback & Time \& Distance \\
Technology Features & Time, Distance, \& Class Size \\
Understanding \& Concern & \\
\hline
\end{tabular}

After the categories were determined, the researcher and a second rater categorized the responses blind to each other. Then, inter-rater agreement was calculated. There were 14 open-ended questions (\#6 Positive Factors and \#7 Negative Factors for each of the Seven Principles). The IRA for 11 questions out of the 14 was above .80 . The IRA for Question \#B2-7 (negative factors for Principle 2), \#B4-6 (positive factors for Principle 4), and \#B7-6 (positive factors for Principle 7) was below .80. The researcher made adjustment to the categories before he and a third rater went through the coding process again. The resulting categories and factor categorization IRA for each of the Seven Principle are shown in Table 9. 
Table 9

IRA for Factor Categorization

\begin{tabular}{cccc}
\hline \multirow{2}{*}{ Principle } & \multicolumn{2}{c}{ Factors } \\
\cline { 2 - 3 } 1 & Positive & & Negative \\
2 & .83 & .83 \\
3 & .83 & .98 \\
4 & .80 & .87 \\
5 & .84 & .89 \\
6 & .85 & .83 \\
7 & .85 & .80 \\
& .82 & .82 \\
\hline
\end{tabular}

Research Question 3: Relationship between Influencing Factors and the Seven Principles Online Implementation

The data sources for Research Question 3 were the Likert scale ratings of the questions (rated 1 to 5) and the demographics. Analyses of variance (ANOVAs) were used to explore the relationship between the major influencing factors and the implementation of the Seven Principles. The independent variables included course subject, classroom teaching experience, online teaching experience, student on-campus participation, instructor age, gender, highest degree obtained, instructor job classification, and class size. Instructor self-reported pedagogical practices (ratings) were the dependent variables. An initial MANOVA was calculated for each independent variable with the ratings of the implementation of the Seven Principles as the dependent variables. MANOVA was used to protect against experiment-wise error rate. If the initial MANOVA was significant at $\alpha=.05$ across all seven dependent variables, subsequent testing of the component ANOVAs was performed at $\alpha=.05$ level. The procedure 
protected against declaring inappropriate (chance) significance when multiple dependent variables were involved.

A brief outline is provided in Table 10 for the research questions, respective data sources, and analysis methods. For research question \#1, the data source includes the five Likert scale items for each of the Seven Principles, and there are 35 items in all. The analysis method includes descriptive statistics, one-way within-subject ANOVAs and Tukey tests. For research question \#2, the data source includes the two open-ended questions for each of the Seven Principles, and there are 14 open-ended questions in all. The analysis method includes 14 case-study categorizations. For research question \#3, the data source includes the demographics and the 35 Likert scale items. The analysis method includes one-way MANOVA, ANOVAs and Tukey tests. 
Table 10

Research Question, Data Source, and Analysis Method

\begin{tabular}{|c|c|c|}
\hline Research Question & Data Source & Analysis \\
\hline \multicolumn{3}{|l|}{ \# 1} \\
\hline $\begin{array}{l}\text { What are online instructors' perceptions } \\
\text { of their implementation of the Seven } \\
\text { Principles? }\end{array}$ & $\begin{array}{l}\text { Likert scale: Items } \\
1-5 \text { for each of } \\
\text { the Seven } \\
\text { Pedagogical } \\
\text { Principles }\end{array}$ & $\begin{array}{l}\text { Descriptive } \\
\text { statistics; } \\
\text { One-way } \\
\text { within-subject } \\
\text { ANOVAs; } \\
\text { Tukey tests for } \\
\text { pair comparison }\end{array}$ \\
\hline \multicolumn{3}{|l|}{ \#2 } \\
\hline $\begin{array}{l}\text { What factors are influencing an online } \\
\text { instructor's level of implementation of } \\
\text { the Seven Principles? }\end{array}$ & $\begin{array}{l}\text { Open-ended } \\
\text { questions: Items } 6 \\
\text { and } 7 \text { for each of } \\
\text { the Seven } \\
\text { Pedagogical } \\
\text { Principles }\end{array}$ & $\begin{array}{l}7 \text { case-study } \\
\text { categorization } \\
\text { and frequency }\end{array}$ \\
\hline \multicolumn{3}{|l|}{ \# 3} \\
\hline $\begin{array}{l}\text { What is the relationship between the } \\
\text { influencing factors and instructors' } \\
\text { perception of the implementation of the } \\
\text { Seven Principles? }\end{array}$ & $\begin{array}{l}\text { Demographics; } \\
\text { Likert scale: Items } \\
1-5 \text { for each of the } \\
\text { Seven Pedagogical } \\
\text { Principles }\end{array}$ & $\begin{array}{l}\text { MANOVAs } \\
\text { ANOVAs } \\
\text { Tukey tests }\end{array}$ \\
\hline
\end{tabular}

Table 11 gives a matrix of the research question and its corresponding questionnaire items. Item 10, "Instruction Delivery Technology" was not used to answer any specific research question. It provided the information for the description of online distance instruction at West Virginia University. 
Table 11

\section{Research Question and Data Source Matrix}

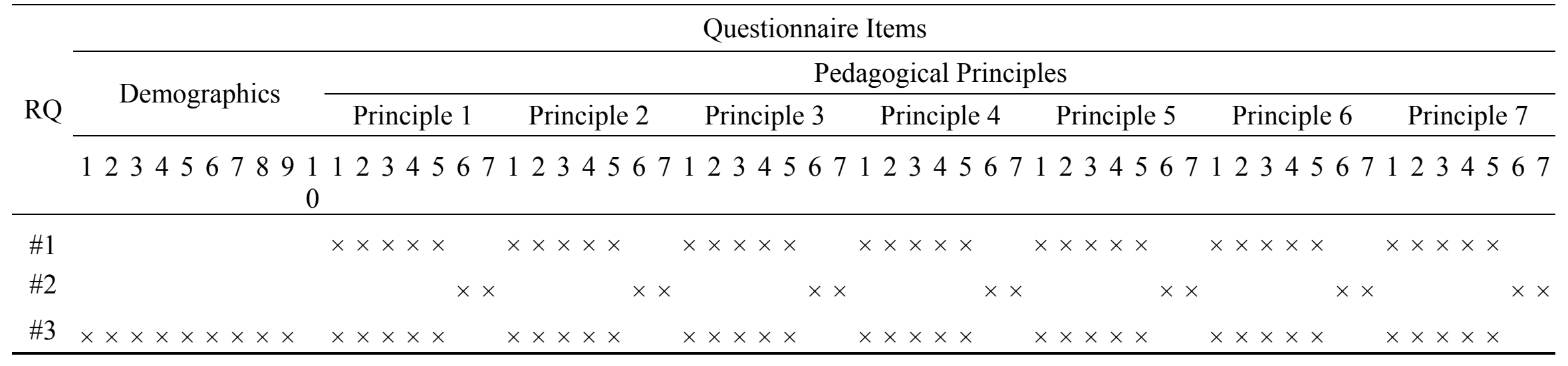

Note. RQ = Research Questions. \#1 What are online instructors' perceptions of their implementation of the Seven Principles? \#2 What factors are influencing an online instructor's level of implementation of the Seven Principles? \#3 What is the relationship between the influencing factors and instructors' perception of the implementation of the Seven Principles? 


\section{CHAPTER 4}

\section{RESULTS}

This chapter presents the results of the survey responses concerning the implementation of the Seven Principles in the online environment. A detailed demographic description of the participants is followed by the findings in relation to the three research questions. SAS $^{\circledR}$ statistical analysis system was used for the analysis and data manipulation.

\section{Descriptive Statistics}

Data were obtained from the participants through the Web-based survey hosted at West Virginia University in September 2005. In total, 48 instructors participated in the survey. One case was dropped from the analysis due to the fact it was incomplete.

Research results from a total of 47 participants are presented here.

The average age of the respondents was 45.35 years, ranging from 26 to 70 . By gender, 14 were male (29.79\%) and 33 were female (70.21\%). By education level, 19 had doctorates (40.43\%), 2 had Juris Doctorates (4.26\%), 21 had master's degrees (44.68\%), and 5 had bachelor's degrees (10.64\%). By job classification, 23 were tenure-track faculty $(48.94 \%), 16$ were non-tenure track faculty $(34.04 \%), 6$ were graduate students (12.77\%), and 2 were staff members (4.26\%). Of the 23 tenure-track instructors, 5 were full professors $(21.74 \%), 4$ were associate professors $(17.39 \%)$, and 14 were assistant professors (60.87\%). The demographics of the participants are presented in Table 12 . 
Table 12

Participant Demographics

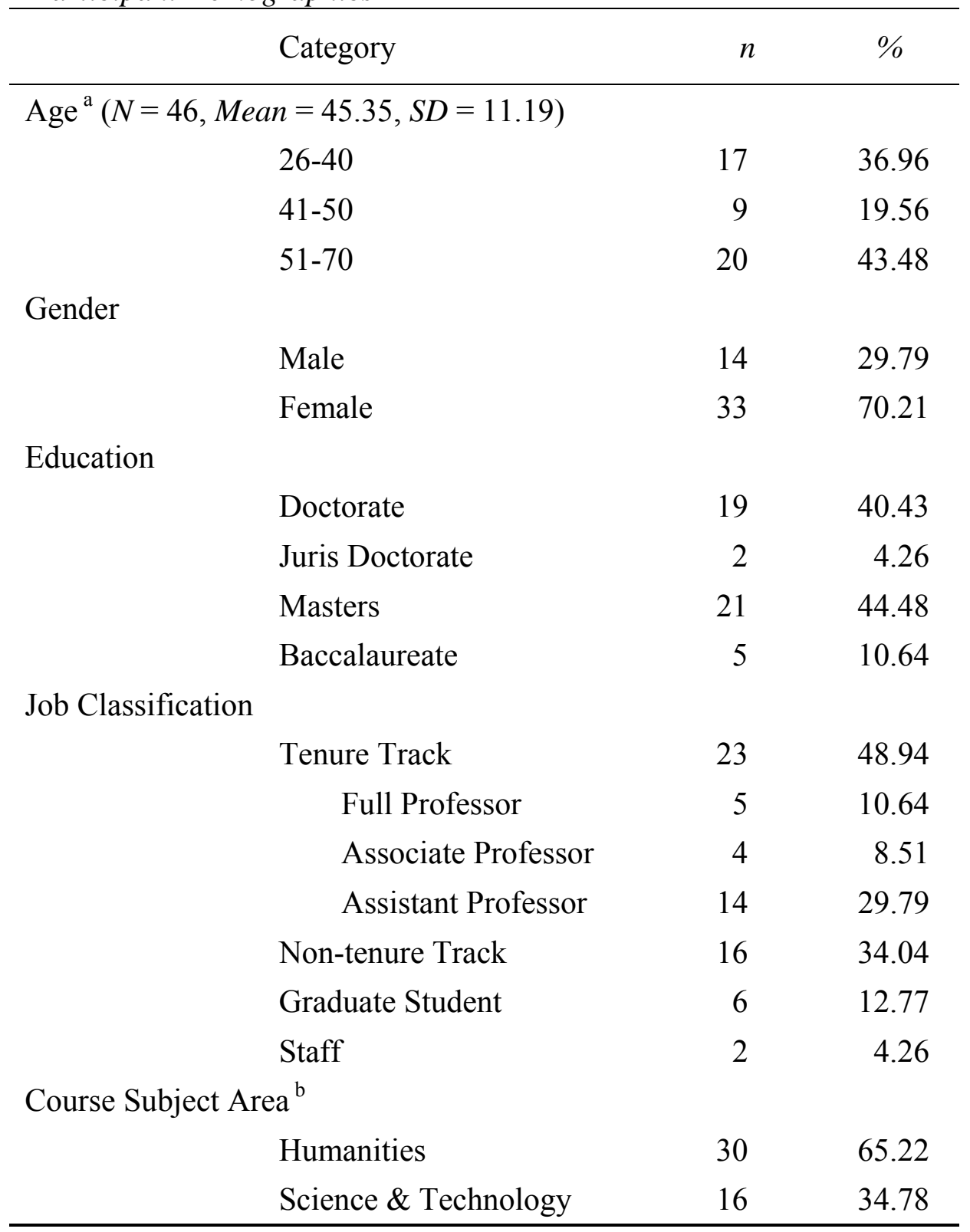

Note. ${ }^{\mathrm{a}}$ One participant did not provide age information. ${ }^{\mathrm{b}}$ One participant did not provide course subject information.

Instructor teaching experience varied from 0 to 40 years, and online teaching experience ranged from 0 to 10 years. Class size of the online courses varied from 1 to 250. All courses used a course Web site for instruction delivery, through either WebCT 
$\operatorname{Vista}^{\mathrm{TM}}$ or SOLE (Secure Online Environment). Streaming video $(n=6,12.77 \%)$, streaming audio $(n=2,4.26 \%)$, and $\operatorname{CD} \operatorname{ROM}(n=2,4.26 \%)$ also were used. More than half of the participants $(n=24)$ had no face-to-face interaction. Of the remaining 23 participants, 16 indicated that they had on-campus instructional activities. On-campus activities varied from one-session initial orientation to scheduled demonstrations or regular face-to-face instructional activities. Table 13 provides some basic information about the participants, their experience, and the class they were teaching.

Table 13

Descriptive Statistics of the Participants and Class Size

\begin{tabular}{rlcc}
\hline Category & & $n$ & $\%$ \\
\hline Teaching Experience $(N=47$, Mean $=10.04, S D=9.52)$ & & \\
$\leq 5$ & Years & 15 & 31.91 \\
$6-10$ & Years & 19 & 40.43 \\
$\geq 11$ & Years & 13 & 27.66 \\
Online Teaching Experience $(N=47$, Mean $=2.94, S D=2.35)$ & \\
$<3$ & Years & 23 & 48.94 \\
$\geq 3$ & Years & 24 & 51.06 \\
32.28$, SD $=42.56$, Min $=1$, Max $=250)$ & \\
$<15$ & Students & 15 & 31.91 \\
$15-30$ & Students & 21 & 44.68 \\
$\geq 31$ & Students & 11 & 23.40 \\
\hline
\end{tabular}


Findings

\section{Research Question 1}

What are online instructors' perceptions of their implementation of the Seven Principles? Faculty self-reported implementation of the Seven Principles in the online environment was determined through the computation of means and standard deviations of questionnaire items in the Pedagogical Principles section of the Online Faculty Inventory. Table 14 through Table 20 presents a general view of what was practiced in the virtual classroom. Each of these tables contains information about the practice of one of the Seven Principles.

The most commonly implemented pedagogy for Principle 1 Encourage StudentFaculty Contact was to “. . . know my students by name by the end of the first two weeks of the term" (Mean =3.68). The least commonly implemented pedagogy for this principle was to “. . . invite or take my students to attend professional meetings or other events in my field" (Mean =2.04). Table 14 presents the $N$, Mean, and Standard Deviation for each strategy for Principle 1. To determine if there was a significant difference among the practice of the five strategies for Principle 1, a one-way withinsubjects analysis of variance (ANOVA) was computed in which Strategy was the independent variable (the five strategies), and Rating (possible range 1 through 5) was the dependent variable. This ANOVA yielded $F(4,184)=25.46, p<.01$, indicating an overall significant difference. A Tukey test was performed to assess multiple comparisons of each pair of means for the use of the five strategies. As may be noted in Table 14, there were significant $(p<.01)$ Tukey test differences for 7 of the 10 multiple comparisons. 
Table 14

Principle 1: Encourage Student-Faculty Contact

\begin{tabular}{llll}
\hline \multicolumn{1}{c}{ Pedagogical Strategy } & $N$ & $M$ & $S D$ \\
\hline $\begin{array}{l}\text { 1. I advise my students about career opportunities in their } \\
\text { major field. }\end{array}$ & 47 & 2.74 & 1.21 \\
$\begin{array}{l}\text { 2. I share my past experiences, attitudes, and values with } \\
\text { students. }\end{array}$ & 47 & 3.55 & 1.28 \\
3. I know my students by name by the end of the first two & 47 & 3.68 & 1.22 \\
$\quad \begin{array}{l}\text { weeks of the term. } \\
\text { 4. I serve as an informal advisor to students via e-mail. }\end{array}$ & 47 & 3.51 & 1.25 \\
5. I invite or take my students to attend professional & 47 & 2.04 & 1.25 \\
\hline
\end{tabular}

Note. Multiple comparisons by the Tukey test indicated significant $(p<.01)$ differences between Strategies $(1>5,2>1,2>5,3>1,3>5,4>1$, and $4>5)$.

The most commonly implemented pedagogy for Principle 2 Encourage Cooperation among Students was to ask students “. . . to discuss key concepts with other students whose backgrounds and viewpoints are different from their own" (Mean = 3.53). The least commonly implemented pedagogy for this principle was to ask students “. . . to evaluate each other's work" (Mean =2.57). Table 15 presents the $N$, Mean, and Standard Deviation for each strategy for Principle 2. To determine if there was a significant difference among the practice of the five strategies for Principle 2, a one-way withinsubjects ANOVA was computed in which Strategy was the independent variable (the five strategies), and Rating (possible range 1 through 5) was the dependent variable. This ANOVA yielded $F(4,184)=6.04, p<.01$, indicating an overall significant difference. A Tukey test was performed to assess multiple comparisons of each pair of means for the 
practice of the five strategies. As may be noted in Table 15 , there were significant $(p<.01)$

Tukey test differences for 2 of the 10 multiple comparisons.

Table 15

Principle 2: Encourage Cooperation Among Students

\begin{tabular}{llcc}
\hline \multicolumn{1}{c}{ Pedagogical Strategy } & $N$ & $M$ & $S D$ \\
\hline $\begin{array}{l}\text { 1. I encourage my students to prepare together for classes or } \\
\text { exams. }\end{array}$ & 47 & 3.02 & 1.42 \\
2. I encourage students to do projects together. & 47 & 2.98 & 1.57 \\
3. I ask my students to evaluate each other's work. & 47 & 2.57 & 1.54 \\
4. I ask my students to discuss key concepts with other & 47 & 3.53 & 1.50 \\
& $\begin{array}{l}\text { students whose backgrounds and viewpoints are different } \\
\text { from their own. }\end{array}$ & & \\
$\begin{array}{l}\text { 5. I create "learning communities," study groups, or project } \\
\text { teams within my courses. }\end{array}$ & 47 & 2.81 & 1.58 \\
\hline
\end{tabular}

Note. Multiple comparisons by the Tukey test indicated significant $(\mathrm{p}<.01)$ differences between Strategies ( $4>3$ and $4>5$ ).

The most commonly implemented pedagogy for Principle 3 Encourage Active Learning was to give “. . concrete, real-life situations to analyze" (Mean $=4.38)$. The least commonly implemented pedagogy for this principle was to ". . carry out research projects with students" $($ Mean $=2.30)$. Table 16 presents the $N$, Mean, and Standard Deviation for each strategy for Principle 3. To determine if there was a significant difference among the practice of the five strategies for Principle 3, a one-way withinsubjects ANOVA was computed in which Strategy was the independent variable (the five strategies), and Rating (possible range 1 through 5) was the dependent variable. This ANOVA yielded $F(4,184)=42.99, p<.01$, indicating an overall significant difference. A Tukey test was performed to assess multiple comparisons of each pair of means for the 
practice of the five strategies. As may be noted in Table 16, there were significant $(p<.01)$ Tukey test differences for 6 of the 10 multiple comparisons.

Table 16

Principle 3: Encourage Active Learning

\begin{tabular}{|c|c|c|c|}
\hline Pedagogical Strategy & $N$ & $M$ & $S D$ \\
\hline $\begin{array}{l}\text { 1. I ask my students to relate outside events or activities to } \\
\text { the subjects covered in my courses. }\end{array}$ & 47 & 4.15 & 1.25 \\
\hline $\begin{array}{l}\text { 2. I encourage students to challenge my ideas, the ideas of } \\
\text { other students, or those presented in readings or other } \\
\text { course materials. }\end{array}$ & 47 & 3.87 & 1.21 \\
\hline $\begin{array}{l}\text { 3. I give my students concrete, real-life situations to } \\
\text { analyze. }\end{array}$ & 47 & 4.38 & 0.85 \\
\hline $\begin{array}{l}\text { 4. I encourage my students to suggest new readings, } \\
\text { research projects, field trips, or other course activities. }\end{array}$ & 47 & 3.32 & 1.38 \\
\hline 5. I carry out research projects with my students. & 47 & 2.30 & 1.37 \\
\hline
\end{tabular}

Note. Multiple comparisons by the Tukey test indicated significant $(\mathrm{p}<.01)$ differences between Strategies $(1>4,1>5,2>5,3>4,3>5$, and $4>5)$.

The most commonly implemented pedagogy for Principle 4 Give Prompt Feedback was to "... return examinations and papers within a week" (Mean $=4.66)$. The least commonly implemented pedagogy for this principle was to ask students to “... schedule conferences (phone calls, chat room, or on-campus) with me to discuss their progress" (Mean $=3.32)$. Table 17 presents the $N$, Mean, and Standard Deviation for each strategy for Principle 4. To determine if there was a significant difference among the practice of the five strategies for Principle 4, a one-way within-subjects ANOVA was computed in which Strategy was the independent variable (the five strategies), and Rating (possible range 1 through 5 ) was the dependent variable. This ANOVA yielded $F(4,184)$ 
$=10.27, p<.01$, indicating an overall significant difference. A Tukey test was performed to assess multiple comparisons of each pair of means for the practice of the five strategies. As may be noted in Table 17, there were significant $(p<.01)$ Tukey test differences for 4 of the 10 multiple comparisons.

Table 17

Principle 4: Give Prompt Feedback

\begin{tabular}{llll}
\hline \multicolumn{1}{c}{ Pedagogical Strategy } & $N$ & $M$ & $S D$ \\
\hline $\begin{array}{l}\text { 1. I prepare online activities which give students immediate } \\
\text { feedback on how well they do. }\end{array}$ & 47.17 & 1.07 \\
$\begin{array}{l}\text { 2. I return examinations and papers within a week. } \\
\begin{array}{l}\text { I give students detailed evaluations of their work early in } \\
\text { the term. }\end{array}\end{array}$ & 47 & 4.66 & 0.81 \\
$\begin{array}{l}\text { 4. } \\
\text { I ask my students to schedule conferences (phone calls, } \\
\text { chat room, or on-campus) with me to discuss their } \\
\text { progress. }\end{array}$ & 47 & 3.32 & 1.46 \\
$\begin{array}{l}\text { 5. I give my students written comments on their strengths } \\
\text { and weaknesses on exams and papers. }\end{array}$ & 47 & 3.85 & 1.38 \\
\hline
\end{tabular}

Note. Multiple comparisons by the Tukey test indicated significant $(\mathrm{p}<.01)$ differences between Strategies $(1>4,2>4,2>5$, and $3>4)$.

The most commonly implemented pedagogy for Principle 5 Emphasize Time on Task was to ". . . expect my students to complete their assignments promptly" (Mean = 4.66). The least commonly implemented pedagogy for this principle was when "... students miss my classes, I require them to make up lost work" $($ Mean $=3.53)$. Table 18 presents the N, Mean, and Standard Deviation for each strategy for Principle 5. To determine if there was a significant difference among the practice of the five strategies for Principle 5, a one-way within-subjects ANOVA was computed in which Strategy was 
the independent variable (the five strategies), and Rating (possible range 1 through 5) was the dependent variable. This ANOVA yielded $F(4,184)=9.74, p<.01$, indicating an overall significant difference. A Tukey test was performed to assess multiple comparisons of each pair of means for the practice of the five strategies. As may be noted in Table 18, there were significant $(p<.01)$ Tukey test differences for 4 of the 10 multiple comparisons.

Table 18

Principle 5: Emphasize Time on Task

\begin{tabular}{llll}
\hline \multicolumn{1}{c}{ Pedagogical Strategy } & $N$ & $M$ & $S D$ \\
\hline $\begin{array}{l}\text { 1. I expect my students to complete their assignments } \\
\text { promptly. }\end{array}$ & 47 & 4.66 & 0.73 \\
$\begin{array}{l}\text { 2. I clearly communicate to my students the minimum } \\
\text { amount of time they should spend preparing for classes. }\end{array}$ & 47 & 3.83 & 1.20 \\
$\begin{array}{l}\text { 3. I underscore the importance of regular work, steady } \\
\text { application, sound self-pacing, and scheduling. }\end{array}$ & 47 & 4.40 & 0.83 \\
$\begin{array}{l}\text { 4. I contact students who fall behind to discuss their study } \\
\text { habits, schedules, and other commitments. }\end{array}$ & 47 & 3.89 & 1.15 \\
$\begin{array}{l}\text { 5. If students miss my classes, I require them to make up } \\
\text { lost work. }\end{array}$ & 47 & 3.53 & 1.52 \\
\hline
\end{tabular}

Note. Multiple comparisons by the Tukey test indicated significant $(\mathrm{p}<.01)$ differences between Strategies $(1>2,1>4,1>5$, and 3>5).

The most commonly implemented pedagogy for Principle 6 Communicate High Expectations was to "... make clear my expectations in writing at the beginning of the course" (Mean $=4.74)$. The least commonly implemented pedagogy for this principle was to “. . . help students set challenging goals for their own learning” (Mean = 3.68). Table 19 presents the $N$, Mean, and Standard Deviation for each strategy for Principle 6. 
To determine if there was a significant difference among the practice of the five strategies for Principle 6, a one-way within-subjects ANOVA was computed in which Strategy was the independent variable (the five strategies), and Rating (possible range 1 through 5) was the dependent variable. This ANOVA yielded $F(4,184)=17.23, p<.01$, indicating an overall significant difference. A Tukey test was performed to assess multiple comparisons of each pair of means for the practice of the five strategies. As may be noted in Table 19, there were significant $(p<.01)$ Tukey test differences for 5 of the 10 multiple comparisons.

Table 19

Principle 6: Communicate High Expectations

\begin{tabular}{|c|c|c|c|}
\hline Pedagogical Strategy & $N$ & $M$ & $S D$ \\
\hline $\begin{array}{l}\text { 1. I tell students that I expect them to work hard in my } \\
\text { classes. }\end{array}$ & 47 & 4.30 & 0.91 \\
\hline $\begin{array}{l}\text { 2. I emphasize the importance of holding high standards for } \\
\text { academic achievement. }\end{array}$ & 47 & 4.28 & 1.06 \\
\hline $\begin{array}{l}\text { 3. I make clear my expectations in writing at the beginning } \\
\text { of the course. }\end{array}$ & 47 & 4.74 & 0.71 \\
\hline $\begin{array}{l}\text { 4. I help students set challenging goals for their own } \\
\text { learning. }\end{array}$ & 47 & 3.68 & 1.14 \\
\hline $\begin{array}{l}\text { 5. I explain to students what will happen if they do not } \\
\text { complete their work on time. }\end{array}$ & 47 & 4.62 & 0.85 \\
\hline
\end{tabular}

Note. Multiple comparisons by the Tukey test indicated significant $(\mathrm{p}<.01)$ differences between Strategies $(1>4,2>4,3>2,3>4$, and $5>4)$.

The most commonly implemented pedagogy for Principle 7 Respect Diverse Talents and Ways of Learning was to “. . . encourage students to speak up when they don't understand" $($ Mean $=4.60)$. The least commonly implemented pedagogy for this 
principle was to “. . . integrate new knowledge about women and other under-represented populations into my courses" (Mean $=3.32)$. Table 20 presents the $N$, Mean, and Standard Deviation for each strategy for Principle 7. To determine if there was a significant difference among the practice of the five strategies for Principle 7, a one-way within-subjects ANOVA was computed in which Strategy was the independent variable (the five strategies), and Rating (possible range 1 through 5) was the dependent variable. This ANOVA yielded $F(4,184)=14.58, p<.01$, indicating an overall significant difference. A Tukey test was performed to assess multiple comparisons of each pair of means for the practice of the five strategies. As may be noted in Table 20, there were significant $(p<.01)$ Tukey test differences for 4 of the 10 multiple comparisons.

Table 20

Principle 7: Respect Diverse Talents and Ways of Learning

\begin{tabular}{|c|c|c|c|}
\hline Pedagogical Strategy & $N$ & $M$ & $S D$ \\
\hline $\begin{array}{l}\text { 1. I encourage students to speak up when they don't } \\
\text { understand. }\end{array}$ & 47 & 4.60 & 0.71 \\
\hline $\begin{array}{l}\text { 2. I use diverse teaching activities to address a broad } \\
\text { spectrum of students. }\end{array}$ & 47 & 3.87 & 1.10 \\
\hline $\begin{array}{l}\text { 3. I select readings and design activities related to the } \\
\text { background of my students. }\end{array}$ & 47 & 3.49 & 1.18 \\
\hline $\begin{array}{l}\text { 4. I integrate new knowledge about women and other under- } \\
\text { represented populations into my courses. }\end{array}$ & 47 & 3.32 & 1.51 \\
\hline $\begin{array}{l}\text { 5. I try to find out about my students' learning styles, } \\
\text { interests or backgrounds at the beginning of each course. }\end{array}$ & 47 & 3.47 & 1.50 \\
\hline
\end{tabular}

Note. Multiple comparisons by the Tukey test indicated significant $(\mathrm{p}<.01)$ differences between Strategies ( $1>2,1>3,1>4$, and 1>5). 
As is shown in Table 21, of all the Seven Principles, the most commonly implemented principle was Principle 6 Communicate High Expectations (Mean $=4.32$ ). The least commonly practiced principle was Principle 2 Encourage Cooperation Among Students $($ Mean $=2.98)$.

Table 21

Overall Implementation of the Seven Principles

\begin{tabular}{llll}
\hline \multicolumn{1}{c}{ Principles } & $N$ & $M$ & $S D$ \\
\hline 1. Encourage Student-Faculty Contact & 47 & 3.11 & 0.90 \\
2. Encourage Cooperation Among Students & 47 & 2.98 & 1.24 \\
3. Encourage Active Learning & 47 & 3.60 & 0.95 \\
4. Give Prompt Feedback & 47 & 4.03 & 0.72 \\
5. Emphasize Time on Task & 47 & 4.06 & 0.67 \\
6. Communicate High Expectations & 47 & 4.32 & 0.72 \\
7. Respect Diverse Talents and Ways of Learning & 47 & 3.75 & 0.92 \\
\hline
\end{tabular}

Note. Multiple comparisons by the Tukey test indicated significant $(\mathrm{p}<.01)$ differences between Principles $(3>1,3>2,4>1,4>2,5>1,5>2,5>3,6>1,6>2,6>3$, $6>7,7>1$, and $7>2$ ).

Table 21 presents the N, Mean, and Standard Deviation for each of the Seven Principles. To determine if there was a significant difference among the implementation of the Seven Principles, a one-way within-subjects ANOVA was computed. This ANOVA yielded $F(6,276)=30.07, p<.01$, indicating an overall significant difference. A Tukey test was performed to assess multiple comparisons of each pair of means for the implementation of the Seven Principles. As may be noted in Table 21, there were significant $(p<.01)$ Tukey test differences for 13 of the 21 multiple comparisons. 
In answer to Research Question 1, What are online instructors' perceptions of their implementation of the Seven Principle, significant $(\mathrm{p}<.01)$ differences were found for the Strategies that the participants used to accomplish each of the Seven Principles. Significant differences $(\mathrm{p}<.01)$ also were found for the implementation of the Seven Principles. The order of implementation with reference to the means, from most to least, was (6) Communicate High Expectations, (5) Emphasize Time on Task, (4) Give Prompt Feedback, (7) Respect Diverse Talents and Ways of Learning, (3) Encourage Active Learning, (1) Encourage Student-Faculty Contact, and (2) Encourage Cooperation Among Students.

\section{Research Question 2}

What factors are influencing an online instructor's level of implementation of the Seven Principles? The data sources for Research Question 2 were Items 6 and 7, the two open-ended questions at the end of each principle. Responses to these open-ended questions were qualitative data. Since subjective judgment was involved, a second rater participated in the categorization process.

Shown in Table 22 are the factors that participants believed to have positive effects on the implementation of the Seven Principles. The categories of positive factors for each principle are reported. For example, of the 47 participants, 23 of them mentioned accessibility and availability of the instructor as a positive factor for the implementation of Principle 1 Encourage Student-Faculty Contact. 
Table 22

Positive Factors for Pedagogical Practice

\begin{tabular}{llll}
\hline Principles & Categories & $f$ & $\%$ \\
\hline
\end{tabular}

1. Encourage Student-Faculty Contact ${ }^{\mathrm{a}}$

Accessibility \& Availability $\quad 23 \quad 50.00$

Technology Features $\quad 13 \quad 28.26$

2. Encourage Cooperation Among Students ${ }^{a}$

$\begin{array}{lll}\text { Instructional Strategies } & 27 & 58.70\end{array}$

$\begin{array}{lll}\text { Technology Features } & 7 & 15.22\end{array}$

3. Encourage Active Learning ${ }^{\mathrm{a}}$

$\begin{array}{lll}\text { Instructional Activities } & 16 & 34.78\end{array}$

$\begin{array}{lrr}\text { Content Materials } & 13 \quad 28.26\end{array}$

$\begin{array}{lll}\text { Communications } & 3 & 6.52\end{array}$

4. Give Prompt Feedback ${ }^{\mathrm{a}}$

$\begin{array}{lll}\text { Technology Features } & 18 & 39.13\end{array}$

$\begin{array}{lll}\text { Instructional Strategies } & 13 & 28.26\end{array}$

$\begin{array}{lll}\text { Accessibility \& Availability } & 8 & 17.39\end{array}$

5. Emphasize Time on Task ${ }^{\mathrm{a}}$

Rules \& Encouragement $\quad 29 \quad 63.04$

$\begin{array}{lll}\text { Instructional Activities } & 8 & 17.39\end{array}$

6. Communicate High Expectations ${ }^{\mathrm{a}}$

$\begin{array}{lll}\text { Syllabus \& Feedback } & 23 & 50.00\end{array}$

Challenges \& Rules $\quad 14 \quad 30.43$

7. Encourage Student-Faculty Contact ${ }^{\mathrm{b}}$

$\begin{array}{lll}\text { Instructional Strategies } & 19 & 42.22\end{array}$

Understanding \& Concern $\quad 14 \quad 31.11$

$\begin{array}{lll}\text { Personal Contact } & 2 & 4.44\end{array}$

Note. ${ }^{\mathrm{a}} N=46 .{ }^{\mathrm{b}} N=45$.

Shown in Table 23 are the factors that have negative effects on the implementation of the Seven Principles. The categories of negative factors for each principle are reported. For example, of the 47 participants, 23 of them mentioned time 
and distance as a negative factor for the implementation of Principle 1 Encourage Student-Faculty Contact. "Time and distance" was the most prominent negative factors that impacted the implementation of each of the Seven Principles.

Table 23

Negative Factors for Pedagogical Practice

\begin{tabular}{lll}
\hline Principles & Categories & $f$
\end{tabular}

1. Encourage Student-Faculty Contact ${ }^{\mathrm{a}}$

$\begin{array}{lll}\text { Time \& Distance } & 23 & 50.00 \\ \text { Lack of Student Involvement } & 14 & 30.43\end{array}$

2. Encourage Cooperation Among Students ${ }^{\mathrm{a}}$

Time \& Distance $\quad 13 \quad 28.26$

Lack of Student Involvement $\quad 9 \quad 19.57$

$\begin{array}{lll}\text { Technology Competence } & 3 & 6.52\end{array}$

3. Encourage Active Learning ${ }^{\mathrm{a}}$

Time \& Distance $\quad 12 \quad 26.09$

Lack of Student Involvement $\quad 10 \quad 21.74$

$\begin{array}{lll}\text { Class Size } & 3 & 6.52\end{array}$

4. Give Prompt Feedback ${ }^{\mathrm{b}}$

$\begin{array}{lll}\text { Time \& Distance } & 14 & 31.11\end{array}$

$\begin{array}{lrr}\text { Technology } & 8 & 17.78\end{array}$

$\begin{array}{lll}\text { Class Size } & 4 & 8.89\end{array}$

5. Emphasize Time on Task ${ }^{\mathrm{a}}$

$\begin{array}{lll}\text { Student Negligence } & 14 & 30.43\end{array}$

Time, Distance, \& Class Size $\quad 15 \quad 32.61$

$\begin{array}{lrr}\text { Technical Difficulties } & 4 & 8.70\end{array}$

6. Communicate High Expectations ${ }^{a}$

$\begin{array}{lll}\text { Motivation \& Negligence } & 17 & 36.96\end{array}$

Time \& Distance $\quad 8 \quad 17.39$ 
7. Encourage Student-Faculty Contact ${ }^{\mathrm{b}}$

Time \& Distance $\quad 15 \quad 33.33$

Content \& Design $\quad 12 \quad 26.67$

Motivation \& Negligence $\quad 5 \quad 11.11$

Note. ${ }^{\mathrm{a}} N=46 .{ }^{\mathrm{b}} N=45$.

Table 24 presents a summary of all the positive and negative factors reported

from the survey. The overall valid responses for positive factors across all seven principles were 250. This number excluded responses such as "N/A" and "None." A response also was considered invalid if it failed to indicate a factor in the implementation. The most outstanding positive factors included "Instructional Strategies" $(\mathrm{n}=59,23.60$ \%), "Technology Features" ( $\mathrm{n}=38,15.20 \%)$, and "Accessibility \& Availability" ( $\mathrm{n}=31$, 12.40). The overall valid responses for negative factors across all seven principles were 203. The most outstanding negative factors included "Time \& Distance" ( $\mathrm{n}=85,41.87$ \%), "Lack of Student Involvement” ( $\mathrm{n}=33,16.26 \%)$, "Motivation \& Negligence” (n = $22,10.84 \%)$. 
Table 24

Factors versus Overall Responses

\begin{tabular}{lcc}
\hline \multicolumn{1}{c}{ Categories } & $n$ & $\%$ \\
\hline Positive $^{\text {a }}$ & 59 & 23.60 \\
Instructional Strategies & 38 & 15.20 \\
Technology Features & 31 & 12.40 \\
Accessibility \& Availability & 29 & 11.60 \\
Rules \& Encouragement & 24 & 9.60 \\
Instructional Activities & 23 & 9.20 \\
Syllabus \& Feedback & 14 & 5.60 \\
Challenges \& Rules & 14 & 5.60 \\
Understanding \& Concern & 13 & 5.20 \\
Content Materials & 3 & 1.20 \\
Communications & 2 & 0.80 \\
Personal Contact & & \\
Negative ${ }^{\text {b }}$ & 12 & 5.91 \\
Time \& Distance & 85 & 41.87 \\
Lack of Student Involvement & 33 & 16.26 \\
Motivation \& Negligence & 22 & 10.84 \\
Technology Competence/Technical & & \\
$\quad$ Difficulties/Technology & 15 & 7.39 \\
Time, Distance, \& Class Size & 15 & 7.39 \\
Student Negligence & 14 & 6.90 \\
Content \& Design & & \\
Class Size & & \\
\hline & & \\
\hline
\end{tabular}

Note. ${ }^{\mathrm{a}}$ Overall valid responses $N=250 .{ }^{\mathrm{b}}$ Overall valid responses $N=203$.

In answer to Research Question 2, What factors are influencing an online instructor's level of implementation of the Seven Principles, "Instructional Strategies" and "Instructional Activities" were reported as positive factors for five of the Seven Principles. "Technology Features" and instructor "Accessibility \& Availability" also 
were portrayed prominently as factors that helped online implementation of the Seven Principles (see Table 22). “Time and Distance" was reported as a negative factor for all seven of the Seven Principles (see Table 23). "Lack of Student Involvement," "Motivation \& Negligence," and "Technology Competence" were described as factors that barricaded the implementation of the Seven Principles in the online environment. Of all the factors that were reported as helping the implementation of the Seven Principles, "Instructional Strategies" was mentioned 59 times, which accounted for $23.60 \%$ of all the positive factors reported. "Technology Features" was mentioned 38 times, accounting for $15.20 \%$ of the total. Of all the factors that were reported as barricading the implementation of the Seven Principles, "Time \& Distance” was mentioned 85 times, which accounted for $41.87 \%$ of all the negative factors reported. "Lack of Student Involvement" was mentioned 33 times, accounting for $16.26 \%$ of the total (see Table 24 ).

\section{Research Question 3}

What is the relationship between the influencing factors and instructors' perception of the implementation of the Seven Principles? To answer this research question, several independent variables were analyzed in connection with the dependent variables.

The independent variables included (a) Course Subject Area, (b) Class Size, (c) Instructor Age, (d) Gender, (e) Teaching Experience, (f) Online Teaching Experience, (g) On-Campus Face-To-Face Instruction, (h) Highest Degree Obtained, and (i) Instructor Job Classification. The dependent variables were instructor self-reported implementation of the Seven Principles. Findings for this research question are reported in the following section by independent variables. 
Course Subject Area, as an independent variable divided all the online courses into two Course Subject Area categories, (1) Humanities and (2) Science and Technology. The mean for the 30 participants in Humanities was $M=3.75(S D=0.54)$ across all seven pedagogical principles items. The means for the 16 Science \& Technology participants was $M=3.56(S D=0.47)$ across all seven pedagogical principles items. Table 25 presents a summary of the ratings for each of the Seven Principles by Course Subject Area. For example, one of the 30 participants in the Humanities group rated her practice of the five strategies in "1. Student-Faculty Contact" as 1, 1, 3, 1, and 1. Her rating yielded a mean of 1.40, which was reported in the "Min" column of Table 25.

Table 25

Course Subject Area by the Seven Principles Implementation

\begin{tabular}{|c|c|c|c|c|c|c|c|c|c|}
\hline & \multirow{2}{*}{ Principles } & \multicolumn{4}{|c|}{$\begin{array}{l}\text { Humanities } \\
(n=30)\end{array}$} & \multicolumn{4}{|c|}{$\begin{array}{l}\text { Science \& Technology } \\
(n=16)\end{array}$} \\
\hline & & Min & Max & $M$ & $S D$ & Min & Max & M & $S D$ \\
\hline 1. & Student-Faculty Contact & 1.40 & 5.00 & 3.20 & 0.88 & 1.20 & 4.60 & 2.93 & 0.98 \\
\hline 2. & Cooperation Among Students & 1.00 & 5.00 & 2.86 & 1.21 & 1.00 & 4.80 & 3.24 & 1.35 \\
\hline 3. & Active Learning & 1.60 & 5.00 & 3.80 & 0.83 & 1.20 & 5.00 & 3.21 & 1.08 \\
\hline 4. & Prompt Feedback & 2.00 & 5.00 & 4.03 & 0.77 & 2.80 & 5.00 & 3.98 & 0.64 \\
\hline 5. & Time on Task & 1.60 & 5.00 & 4.13 & 0.68 & 2.40 & 4.80 & 3.89 & 0.63 \\
\hline 6. & High Expectations & 1.20 & 5.00 & 4.37 & 0.81 & 3.20 & 4.80 & 4.19 & 0.52 \\
\hline 7. & $\begin{array}{l}\text { Diverse Talents and Ways of } \\
\text { Learning }\end{array}$ & 1.80 & 5.00 & 3.87 & 0.84 & 1.60 & 5.00 & 3.45 & 0.98 \\
\hline
\end{tabular}

Note. One participant did not provide course subject information.

A Multivariate Analysis of Variance (MANOVA) was computed to determine whether difference existed for Course Subject Area of Humanities versus Science \& 
Technology (independent variable) on the mean ratings by each participant on the Seven Principles (seven dependent variables). This one-way MANOVA revealed a significant multivariate main effect for Course Subject Area [Wilks' $\Lambda=.68, F(7,38)=2.60, p$ $<.05]$. The follow-up Analyses of Variance (ANOVAs) indicated a significant Course Subject Area difference in the implantation of Principle 3 Encourage Active Learning $[F$ $(1,44)=4.20, p<.05]$. Participants in the Humanities group reported significantly higher than their Science \& Technology counterparts in implementing the principle of Encourage Active Learning.

Class Size as an independent variable divided the participants into three groups (1) Less than 15 Students, (2) 15 to 30 Students, and (3) More than 30 Students. The mean for the 15 participants in the Less than 15 Students group was $M=3.90(S D=0.50)$ across all seven pedagogical principles items. The mean for the 21 participants in the 15 to 30 Students group was $M=3.48(S D=0.58)$ across all seven pedagogical principles items. The mean for the 11 participants in the More than 30 Students group was $M=3.82$ $(S D=0.46)$ across all seven pedagogical principles items. Table 26 presents a summary of the ratings for each of the Seven Principles by Class Size.

A MANOVA was calculated to determine whether difference existed for Class Size of Less than 15 Students, 15 to 30 Students, and More than 30 Students (independent variable) on the mean ratings by each participant on the Seven Principles (seven dependent variables). This one-way MANOVA did not yield a statistically significant finding [Wilks' $\Lambda=.59, F(14,76)=1.66, p>.05$ ]. Accordingly, follow-up ANOVAs were not computed. Class Size, thus, was not found to be related to implementation of the Seven Principles. 
Table 26

Class Size by the Seven Principles Implementation

\begin{tabular}{|c|c|c|c|c|c|c|c|c|c|c|c|c|}
\hline \multirow[t]{2}{*}{ Principles } & \multicolumn{4}{|c|}{$\begin{array}{l}\text { Less than } 15 \text { Students } \\
\qquad(n=15)\end{array}$} & \multicolumn{4}{|c|}{$\begin{array}{l}15 \text { to } 30 \text { Students } \\
(n=21)\end{array}$} & \multicolumn{4}{|c|}{$\begin{array}{l}\text { More than } 30 \text { Students } \\
(n=11)\end{array}$} \\
\hline & Min & $\operatorname{Max}$ & $M$ & $S D$ & Min & $\operatorname{Max}$ & $M$ & $S D$ & Min & $\operatorname{Max}$ & $M$ & $S D$ \\
\hline 1. Student-Faculty Contact & 1.20 & 4.40 & 3.53 & 0.80 & 1.20 & 5.00 & 2.88 & 0.98 & 1.80 & 4.40 & 2.96 & 0.75 \\
\hline 2. Cooperation Among Students & 1.00 & 4.80 & 3.00 & 1.12 & 1.00 & 5.00 & 2.58 & 1.32 & 1.80 & 5.00 & 3.73 & 0.96 \\
\hline 3. Active Learning & 1.60 & 5.00 & 3.91 & 0.79 & 1.20 & 5.00 & 3.41 & 1.14 & 2.40 & 4.80 & 3.56 & 0.67 \\
\hline 4. Prompt Feedback & 2.40 & 5.00 & 4.11 & 0.69 & 2.00 & 5.00 & 3.90 & 0.84 & 3.00 & 5.00 & 4.15 & 0.53 \\
\hline 5. Time on Task & 2.40 & 5.00 & 4.21 & 0.66 & 1.60 & 5.00 & 3.91 & 0.67 & 3.00 & 5.00 & 4.15 & 0.69 \\
\hline 6. High Expectations & 3.40 & 5.00 & 4.52 & 0.49 & 1.20 & 5.00 & 4.19 & 0.93 & 3.40 & 5.00 & 4.31 & 0.48 \\
\hline $\begin{array}{l}\text { 7. Diverse Talents and Ways of } \\
\text { Learning }\end{array}$ & 2.40 & 5.00 & 3.99 & 0.87 & 1.60 & 5.00 & 3.52 & 0.97 & 2.40 & 5.00 & 3.85 & 0.84 \\
\hline
\end{tabular}


Instructor Age as an independent variable divided the participants into two groups (1) Less than 40 Years and (2) 40 Years and Over. The mean for the 16 participants in Less than 40 Years group was $M=3.71(S D=0.41)$ across all seven pedagogical principles items. The mean for the 30 participants in the 40 Years and Over group was $M$ $=3.67(S D=0.54)$ across all seven pedagogical principles items. Table 27 presents a summary of the ratings for each of the Seven Principles by Instructor Age.

Table 27

Age by the Seven Principles Implementation

\begin{tabular}{|c|c|c|c|c|c|c|c|c|}
\hline \multirow{2}{*}{ Principles } & \multicolumn{4}{|c|}{$\begin{array}{l}\text { Less than } 40 \text { Years } \\
\qquad(n=16)\end{array}$} & \multicolumn{4}{|c|}{$\begin{array}{c}40 \text { Years and Over } \\
(n=30)\end{array}$} \\
\hline & Min & $\operatorname{Max}$ & $M$ & $S D$ & Min & $\operatorname{Max}$ & $M$ & $S D$ \\
\hline 1. Student-Faculty Contact & 1.40 & 4.40 & 3.21 & 0.92 & 1.20 & 5.00 & 3.05 & 0.92 \\
\hline 2. Cooperation Among Students & 1.00 & 5.00 & 3.15 & 1.17 & 1.00 & 5.00 & 2.91 & 1.31 \\
\hline 3. Active Learning & 1.60 & 5.00 & 3.71 & 0.82 & 1.20 & 5.00 & 3.53 & 1.03 \\
\hline 4. Prompt Feedback & 2.00 & 5.00 & 3.96 & 0.84 & 2.40 & 5.00 & 4.04 & 0.67 \\
\hline 5. Time on Task & 1.60 & 5.00 & 3.91 & 0.80 & 2.40 & 5.00 & 4.12 & 0.58 \\
\hline 6. High Expectations & 1.20 & 5.00 & 4.29 & 0.97 & 3.20 & 5.00 & 4.32 & 0.57 \\
\hline $\begin{array}{l}\text { 7. Diverse Talents and Ways of } \\
\text { Learning }\end{array}$ & 1.80 & 5.00 & 3.71 & 1.03 & 1.60 & 5.00 & 3.73 & 0.85 \\
\hline
\end{tabular}

Note. One participant did not provide age information.

A MANOVA was calculated to determine whether difference existed for Instructor Age of Less than 40 Years versus 40 Years and Over (independent variable) on the mean ratings by each participant on the Seven Principles (seven dependent variables). This one-way MANOVA did not yield a statistically significant finding 
[Wilks' $\Lambda=.96, F(7,39)=.25, p>.05]$. Accordingly, follow-up ANOVAs were not computed. Instructor Age, thus, was not found to be related to implementation of the Seven Principles.

Instructor Gender as an independent variable divided the participants into two groups (1) Male and (2) Female. The mean for the 14 participants in Male group was $M=$ $3.64(S D=0.51)$ across all seven pedagogical principles items. The mean for the 33 participants in the Female group was $M=3.71(S D=0.51)$ across all seven pedagogical principles items. Table 28 presents a summary of the ratings for each of the Seven Principles by Instructor Gender.

\section{Table 28}

Gender by the Seven Principles Implementation

\begin{tabular}{|c|c|c|c|c|c|c|c|c|}
\hline \multirow{2}{*}{ Principles } & \multicolumn{4}{|c|}{$\begin{array}{c}\text { Male } \\
(n=14)\end{array}$} & \multicolumn{4}{|c|}{$\begin{array}{l}\text { Female } \\
(n=33)\end{array}$} \\
\hline & Min & Max & $M$ & $S D$ & Min & $\operatorname{Max}$ & $M$ & $S D$ \\
\hline 1. Student-Faculty Contact & 1.20 & 4.60 & 3.04 & 0.94 & 1.20 & 5.00 & 3.13 & 0.90 \\
\hline 2. Cooperation Among Students & 1.00 & 5.00 & 2.96 & 1.36 & 1.00 & 5.00 & 2.99 & 1.21 \\
\hline 3. Active Learning & 1.60 & 5.00 & 3.76 & 0.91 & 1.20 & 5.00 & 3.54 & 0.97 \\
\hline 4. Prompt Feedback & 2.40 & 5.00 & 4.06 & 0.66 & 2.00 & 5.00 & 4.01 & 0.76 \\
\hline 5. Time on Task & 2.40 & 4.80 & 3.94 & 0.59 & 1.60 & 5.00 & 4.12 & 0.70 \\
\hline 6. High Expectations & 3.40 & 5.00 & 4.30 & 0.54 & 1.20 & 5.00 & 4.33 & 0.80 \\
\hline $\begin{array}{l}\text { 7. Diverse Talents and Ways of } \\
\text { Learning }\end{array}$ & 2.40 & 5.00 & 3.44 & 0.92 & 1.60 & 5.00 & 3.88 & 0.90 \\
\hline
\end{tabular}


A MANOVA was calculated to determine whether difference existed for Instructor Gender of Male versus Female (independent variable) on the mean ratings by each participant on the Seven Principles (seven dependent variables). This one-way MANOVA did not yield a statistically significant finding [Wilks' $\Lambda=.84, F(7,39)=$ $1.09, p>.05]$. Accordingly, follow-up ANOVAs were not computed. Instructor Gender, thus, was not found to be related to implementation of the Seven Principles.

Teaching Experience as an independent variable divided the participants into three groups (1) Less than 5 Years, (2) 5 to 10 Years, and (3) More than 10 Years. The mean for the 13 participants in the Less than 5 Years group was $M=3.59(S D=0.67)$ across all seven pedagogical principles items. The mean for the 21 participants in the 5 to 10 Years group was $M=3.85(S D=0.46)$ across all seven pedagogical principles items. The mean for the 13 participants in the More than 10 Years group was $M=3.53$ (SD= 0.46) across all seven pedagogical principles items. Table 29 presents a summary of the ratings for each of the Seven Principles by Teaching Experience.

A MANOVA was calculated to determine whether difference existed for Teaching Experience of Less than 5 Years, 5 to 10 Years, and More than 10 Years (independent variable) on the mean ratings by each participant on the Seven Principles (seven dependent variables). This one-way MANOVA did not yield a statistically significant finding [Wilks' $\Lambda=.65, F(14,76)=1.29, p>.05$ ]. Accordingly, follow-up ANOVAs were not computed. Teaching Experience, thus, was not found to be related to implementation of the Seven Principles. 
Table 29

Teaching Experience by the Seven Principles Implementation

\begin{tabular}{|c|c|c|c|c|c|c|c|c|c|c|c|c|}
\hline \multirow[t]{2}{*}{ Principles } & \multicolumn{4}{|c|}{$\begin{array}{l}<5 \text { Years } \\
(n=13)\end{array}$} & \multicolumn{4}{|c|}{$\begin{array}{c}5 \text { to } 10 \text { Years } \\
(n=21)\end{array}$} & \multicolumn{4}{|c|}{$\begin{array}{l}\text { More than 10Years } \\
\qquad(n=13)\end{array}$} \\
\hline & Min & Max & $M$ & $S D$ & Min & Max & $M$ & $S D$ & Min & $\operatorname{Max}$ & $M$ & $S D$ \\
\hline 1. Student-Faculty Contact & 1.20 & 5.00 & 2.97 & 1.06 & 1.40 & 4.20 & 3.20 & 0.80 & 1.20 & 4.60 & 3.09 & 0.95 \\
\hline 2. Cooperation Among $\mathrm{S}$ & 1.00 & 5.00 & 2.46 & 1.24 & 1.00 & 5.00 & 3.32 & 1.15 & 1.00 & 4.80 & 2.95 & 1.29 \\
\hline 3. Active Learning & 1.60 & 5.00 & 3.66 & 1.04 & 1.60 & 4.40 & 3.72 & 0.69 & 1.20 & 5.00 & 3.35 & 1.22 \\
\hline 4. Prompt Feedback & 2.00 & 4.60 & 4.03 & 0.69 & 2.40 & 5.00 & 4.11 & 0.67 & 2.40 & 4.80 & 3.88 & 0.85 \\
\hline 5. Time on Task & 1.60 & 5.00 & 4.05 & 0.89 & 3.20 & 4.80 & 4.11 & 0.43 & 2.40 & 5.00 & 4.00 & 0.77 \\
\hline 6. High Expectations & 1.20 & 5.00 & 4.38 & 1.04 & 3.00 & 5.00 & 4.42 & 0.58 & 3.20 & 5.00 & 4.11 & 0.55 \\
\hline $\begin{array}{l}\text { 7. Diverse Talents and Ways of } \\
\text { Learning }\end{array}$ & 2.00 & 5.00 & 3.60 & 1.01 & 1.80 & 5.00 & 4.10 & 0.80 & 1.60 & 4.60 & 3.34 & 0.83 \\
\hline
\end{tabular}


Online Teaching Experience as an independent variable divided the participants into two groups (1) Less than 3 Years and (2) 3 or More Years. The mean for the 23 participants in the Less than 3 Years group was $M=3.59(S D=0.54)$ across all seven pedagogical principles items. The mean for the 24 participants in the 3 or More Years group was $M=3.79(S D=0.48)$ across all seven pedagogical principles items. Table 30 presents a summary of the ratings for each of the Seven Principles by Online Teaching Experience.

Table 30

Online Teaching Experience by the Seven Principles Implementation

\begin{tabular}{|c|c|c|c|c|c|c|c|c|}
\hline \multirow{2}{*}{ Principles } & \multicolumn{4}{|c|}{$\begin{array}{c}\text { Less than } 3 \text { Years } \\
(n=23)\end{array}$} & \multicolumn{4}{|c|}{$\begin{array}{c}3 \text { or More Years } \\
(n=24)\end{array}$} \\
\hline & Min & $\operatorname{Max}$ & $M$ & $S D$ & Min & $\operatorname{Max}$ & $M$ & $S D$ \\
\hline 1. Student-Faculty Contact & 1.20 & 4.40 & 3.03 & 0.97 & 1.20 & 5.00 & 3.18 & 0.86 \\
\hline 2. Cooperation Among Students & 1.00 & 5.00 & 2.70 & 1.23 & 1.00 & 5.00 & 3.25 & 1.22 \\
\hline 3. Active Learning & 1.20 & 4.80 & 3.66 & 1.00 & 1.60 & 5.00 & 3.55 & 0.91 \\
\hline 4. Prompt Feedback & 2.00 & 5.00 & 3.91 & 0.89 & 3.00 & 5.00 & 4.13 & 0.51 \\
\hline 5. Time on Task & 1.60 & 5.00 & 4.01 & 0.71 & 2.40 & 5.00 & 4.12 & 0.64 \\
\hline 6. High Expectations & 1.20 & 5.00 & 4.18 & 0.91 & 3.40 & 5.00 & 4.46 & 0.47 \\
\hline $\begin{array}{l}\text { 7. Diverse Talents and Ways of } \\
\text { Learning }\end{array}$ & 1.60 & 5.00 & 3.65 & 1.05 & 2.40 & 5.00 & 3.84 & 0.78 \\
\hline
\end{tabular}

A MANOVA was calculated to determine whether difference existed for Online Teaching Experience of Less than 3 Years versus 3 or More Years (independent variable) on the mean ratings by each participant on the Seven Principles (seven dependent variables). This one-way MANOVA did not yield a statistically significant finding 
[Wilks' $\Lambda=.82, F(7,39)=1.25, p>.05]$. Accordingly, follow-up ANOVAs were not computed. Online Teaching Experience, thus, was not found to be related to implementation of the Seven Principles.

On-Campus Instruction as an independent variable divided the participants into two groups (1) 0 Hours and (2) $1-25$ Hours. The mean for the 24 participants in the 0 Hours group was $M=3.65(S D=0.56)$ across all seven pedagogical principles items. The mean for the 17 participants in the $1-25$ Hours group was $M=3.78(S D=0.42)$ across all seven pedagogical principles items. Table 31 presents a summary of the ratings for each of the Seven Principles by On-Campus Instruction.

\section{Table 31}

On-Campus Instruction by the Seven Principles Implementation

\begin{tabular}{|c|c|c|c|c|c|c|c|c|}
\hline \multirow[t]{2}{*}{ Principles } & \multicolumn{4}{|c|}{$\begin{array}{l}0 \text { Hours } \\
(n=24)\end{array}$} & \multicolumn{4}{|c|}{$\begin{array}{c}1-25 \text { Hours } \\
(n=17)\end{array}$} \\
\hline & Min & $\operatorname{Max}$ & $M$ & $S D$ & Min & Max & $M$ & $S D$ \\
\hline 1. Student-Faculty Contact & 1.20 & 4.40 & 2.94 & 0.84 & 1.20 & 5.00 & 3.42 & 0.98 \\
\hline 2. Cooperation Among Students & 1.00 & 5.00 & 2.88 & 1.27 & 1.20 & 4.60 & 3.15 & 1.14 \\
\hline 3. Active Learning & 1.60 & 5.00 & 3.61 & 0.93 & 1.20 & 5.00 & 3.71 & 0.99 \\
\hline 4. Prompt Feedback & 2.00 & 5.00 & 4.05 & 0.73 & 2.40 & 5.00 & 4.01 & 0.75 \\
\hline 5. Time on Task & 1.60 & 5.00 & 3.98 & 0.73 & 2.40 & 5.00 & 4.15 & 0.69 \\
\hline 6. High Expectations & 1.20 & 5.00 & 4.37 & 0.85 & 3.20 & 5.00 & 4.35 & 0.62 \\
\hline $\begin{array}{l}\text { 7. Diverse Talents and Ways of } \\
\text { Learning }\end{array}$ & 1.80 & 5.00 & 3.73 & 0.96 & 1.60 & 5.00 & 3.67 & 0.87 \\
\hline
\end{tabular}

Note. Six cases with on-campus instruction exceeding 25 hours were dropped out because the participants appeared to have misinterpreted the question. 
A MANOVA was calculated to determine whether difference existed for OnCampus Instruction of 0 Hours versus 1 to 25 Hours (independent variable) on the mean ratings by each participant on the Seven Principles (seven dependent variables). This oneway MANOVA did not yield a statistically significant finding [Wilks' $\Lambda=.78, F(7,33)$

$=1.31, p>.05]$. Accordingly, follow-up ANOVAs were not computed. On-Campus Instruction, thus, was not found to be related to implementation of the Seven Principles. Instructor Education Level as an independent variable divided the participants into two groups (1) With Doctorate and (2) Without Doctorate. The mean for the 19 participants in With Doctorate group was $M=3.76(S D=0.39)$ across all seven pedagogical principles items. The mean for the 28 participants in the Without Doctorate group was $M=3.65(S D=0.58)$ across all seven pedagogical principles items. Table 32 presents a summary of the ratings for each of the Seven Principles by Instructor Education Level. 
Table 32

Instructor Education Level by the Seven Principles Implementation

\begin{tabular}{|c|c|c|c|c|c|c|c|c|}
\hline \multirow[t]{2}{*}{ Principles } & \multicolumn{4}{|c|}{$\begin{array}{l}\text { With Doctorate } \\
\quad(n=19)\end{array}$} & \multicolumn{4}{|c|}{$\begin{array}{l}\text { Without Doctorate } \\
\qquad(n=28)\end{array}$} \\
\hline & Min & $\operatorname{Max}$ & $M$ & $S D$ & Min & $\operatorname{Max}$ & $M$ & $S D$ \\
\hline 1. Student-Faculty Contact & 1.40 & 5.00 & 3.28 & 0.88 & 1.20 & 4.20 & 2.99 & 0.92 \\
\hline 2. Cooperation Among Students & 1.00 & 5.00 & 3.32 & 1.17 & 1.00 & 5.00 & 2.76 & 1.26 \\
\hline 3. Active Learning & 1.60 & 5.00 & 3.61 & 0.97 & 1.20 & 5.00 & 3.60 & 0.95 \\
\hline 4. Prompt Feedback & 2.40 & 4.80 & 4.07 & 0.57 & 2.00 & 5.00 & 3.99 & 0.82 \\
\hline 5. Time on Task & 2.40 & 5.00 & 4.07 & 0.75 & 1.60 & 5.00 & 4.06 & 0.63 \\
\hline 6. High Expectations & 3.00 & 5.00 & 4.29 & 0.57 & 1.20 & 5.00 & 4.34 & 0.82 \\
\hline $\begin{array}{l}\text { 7. Diverse Talents and Ways of } \\
\text { Learning }\end{array}$ & 1.80 & 5.00 & 3.65 & 0.87 & 1.60 & 5.00 & 3.81 & 0.96 \\
\hline
\end{tabular}

A MANOVA was calculated to determine whether difference existed for Instructor Education Level of With Doctorate versus Without Doctorate (independent variable) on the mean ratings by each participant on the Seven Principles (seven dependent variables). This one-way MANOVA did not yield a statistically significant finding [Wilks' $\Lambda=.82, F(7,39)=1.25, p>.05]$. Accordingly, follow-up ANOVAs were not computed. Instructor Education Level, thus, was not found to be related to implementation of the Seven Principles.

Job Classification as an independent variable divided the participants into two groups (1) Tenure Track and (2) Other Instructors. The mean for the 23 participants in Tenure Track group was $M=3.68(S D=0.43)$ across all seven pedagogical principles items. The mean for the 24 participants in the Other Instructors group was $M=3.70$ (SD 
$=0.59)$ across all seven pedagogical principles items. Table 33 presents a summary of the ratings for each of the Seven Principles by Job Classification.

Table 33

Job Classification by the Seven Principles Implementation

\begin{tabular}{|c|c|c|c|c|c|c|c|c|c|}
\hline & \multirow{2}{*}{ Principles } & \multicolumn{4}{|c|}{$\begin{array}{c}\text { Tenure Track } \\
(n=23)\end{array}$} & \multicolumn{4}{|c|}{$\begin{array}{c}\text { Other Instructors } \\
\quad(n=24)\end{array}$} \\
\hline & & Min & Max & $M$ & $S D$ & Min & Max & $M$ & $S D$ \\
\hline 1 . & Student-Faculty Contact & 1.20 & 5.00 & 3.24 & 1.08 & 1.60 & 4.20 & 2.98 & 0.70 \\
\hline 2. & Cooperation Among Students & 1.00 & 5.00 & 3.19 & 1.33 & 1.00 & 5.00 & 2.78 & 1.14 \\
\hline 3. & Active Learning & 1.20 & 5.00 & 3.46 & 1.12 & 1.80 & 5.00 & 3.74 & 0.76 \\
\hline 4. & Prompt Feedback & 2.40 & 5.00 & 3.97 & 0.67 & 2.00 & 5.00 & 4.08 & 0.78 \\
\hline 5. & Time on Task & 2.40 & 5.00 & 3.94 & 0.62 & 1.60 & 5.00 & 4.18 & 0.70 \\
\hline 6. & High Expectations & 3.00 & 5.00 & 4.37 & 0.58 & 1.20 & 5.00 & 4.28 & 0.85 \\
\hline 7. & $\begin{array}{l}\text { Diverse Talents and Ways of } \\
\text { Learning }\end{array}$ & 1.60 & 5.00 & 3.60 & 1.00 & 2.00 & 5.00 & 3.89 & 0.82 \\
\hline
\end{tabular}

A MANOVA was calculated to determine whether difference existed for Job Classification of Tenure Track versus Other Instructors (independent variable) on the mean ratings by each participant on the Seven Principles (seven dependent variables). This one-way MANOVA indicated a significant multivariate main effect for Job Classification [Wilks' $\Lambda=.61, F(7,39)=3.50, p<.01$ ]. Nevertheless, follow-up ANOVAs indicated no significant effects. Job Classification, thus, was not found to be related to implementation of the Seven Principles. 
In answer to Research Question 3, What is the relationship between the influencing factors and instructors' perception of the implementation of the Seven Principles, demographic characteristics and course characteristics were tested to explore the existence of any relationship between these characteristics and the implementation of the Seven Principles. Of the tested characteristics, only Course Subject Area indicated significant $(p<.01)$ difference between courses of Humanities versus courses of Science \& Technology. No other significant differences were detected in the analysis. 


\section{CHAPTER 5}

\section{DISCUSSION}

The purpose of this study was to examine and describe instructors' online teaching experience. This study explored instructor's perception of their implementation of pedagogical principles in the online environment, identified factors that influenced their implementation of the principles, and explored the relationship between the influencing factors and the online implementation of the Seven Principles. This chapter presents interpretation of the findings. Recommendation and suggestions for further research are included at the end of the chapter.

\section{Summary of the Results}

Results indicate a significant difference in the implementation of the Seven Principles for Good Practice in Undergraduate Education (Chickering \& Gamson, 1987) among the undergraduate online instructors. Some principles received more emphasis than others. Communicate High Expectations was implemented with significantly higher frequency than other principles, and Encourage Cooperation among Students and Encourage Student-Faculty Contact were least frequently practiced.

Results reveal that "Instructional Strategies" and "Technology Features" positively influenced online implementation of the Seven Principles, whereas "Time \& Distance" negatively impacted such implementations. Other outstanding positive factors include "Accessibility \& Availability" and "Rules \& Encouragement." Other negative factors include "Lack of Student Involvement," "Motivation \& Negligence," and "Technology Competence/Technical Difficulties/Technology." 
Results also show that significant differences in the implementation of the Seven Principles existed between instructors teaching courses in the area of Humanities and instructors teaching courses in the area of Science and Technology. Participants in the Humanities group reported significantly higher implementation of the Seven Principles than participants in the Science and Technology group.

\section{Reflection and Implications}

\section{Implementation of the Seven Principles}

The participants in the present research reported to have implemented the Seven Principles with different emphasis on the individual principles. Of the Seven Principles, Principle 6 Communicate High Expectations received more emphasis than Principle 1 Encourage Student-Faculty Contact, Principle 2 Encourage Cooperation among Students, Principle 3 Encourage Active Learning, and Principle 7 Respect Diverse Talents and Ways of Learning.

High expectations for academic excellence are of crucial importance for creating a learning environment that values and rewards academic achievement. When an instructor "expects students to perform at high levels and support their efforts to meet their high standards, students generally strive to rise to the occasion" (Kuh et al., 2005). This emphasis of Principle 6 reflects the general consensus over the importance of Communicate High Expectations. The five strategies that constitute this principle include (1) I tell students that I expect them to work hard in my classes; (2) I emphasize the importance of holding high standards for academic achievement; (3) I make clear my expectations in writing at the beginning of the course; (4) I help students set challenging goals for their own learning; and (5) I explain to students what will happen if they do not 
complete their work on time. These strategies may be easier to implement. Scott and Tobe (1995) argued that although all students may not do equally well, all can do better. The role of an instructor is "to encourage improvement, not expect equal results of all" (p. 81).

Of the five component strategies for Principle 6, "help students set challenging goals for their own learning" received relatively low ratings in comparison with the other four. Students enrolled to take distance courses are usually "independent, older, married, or having dependents" (Sikora \& Carroll, 2002, iv). They are "autonomous," "selfdirecting” (Knowles, Holton, \& Swanson, 2005, p. 149), and have their objectives and goals when they decide to return to school. Consequently, instructors do not feel the necessity to help them in regard to setting learning objectives and goals for them as they do for the traditional onsite students.

Principle 2 Encourage Cooperation among Students received lowest rating from the online participants. The rating was significantly lower than the implementation of Principles 3, 4, 5, 6, and 7 (see Table 21 for Tukey test details).

Cooperative learning experiences are "an important part of a student's intellectual and personal growth" (Hatfield \& Hatfield, 1995, p. 28). It promotes student learning, retention, satisfaction, social skills, and self-esteem. Palloff and Pratt (2001) argued that "students should be expected to work together to generate deeper levels of understanding and critical evaluation of the material under study" (p. 115). Research has indicated motivational and learning outcomes of collaborative learning in higher education (Alavi, 2005). There are studies of the possible ways in which computers can be utilized in promote student collaborative learning (McAlister, Ravenscroft, \& Scanlon, 2004). Such 
being the case, then what has caused the online instructors to treat this principle differently?

In answer to the open-ended question for this principle, some participants indicated that they did "not promote" the practice of this principle or they believed that this principle "does not apply to an online course." One participant made it clear that he did "not encourage cooperation among students," and considered any form of "collaboration ... as cheating." Anther commented that "This [cooperation] was impossible because the course was online."

There are two broad categories of learning theories: constructivism versus objectivism. Constructivist theory believes that knowledge "has to be discovered, constructed, practiced, and validated by each learner" (Benbunan-Fich, Hiltz, \& Harasim, 2005, p. 21). Constructivists use instructional methods that enable the learners to engage in active exploration and social collaboration. Laboratories, field studies, simulations, and case studies with group discussion are some of the methods widely used. Objectivist theory believes that there is "a single objective reality that exists independently of the learners" (Benbunan-Fich et al. 2005, p. 21), and learning is to understand that objective reality. The instructional methods include instructor-centered model of knowledge transmission.

Concerns about cheating or other forms of academic dishonesty are legitimate for online instructors at distance since there is very little means to rely on for an instructor to check on the students. Nevertheless, concerns over academic dishonesty cannot explain everything. Instructional activities can be designed in such a way that cheating is not an issue. Case studies and group discussion, for example, can be implemented online. Palloff 
and Pratt (2001) believed that the failing of many online programs "stems from the instructor's inability or unwillingness to facilitate a collaborative learning process" ( $\mathrm{p}$. 115). It is clear that how to cultivate cooperation among students in the virtual classroom remains a task for the researchers and instructors.

Principle 1 Encourage Student-Faculty Contact also received low ratings from the participants. The average score was significantly lower than the implementation of Principles 3, 4, 5, 6, and 7 (see Table 21 for Tukey test details).

Frequent student-faculty interaction in and out of class is considered the most important factor in student motivation and involvement. In the face-to-face environment, an instructor can invite a student to drop by his/her office, give advice about career opportunities, share past experiences with students, attend events sponsored by student groups, or have informal talk outside the class. When an instructor is teaching online, some of these possibilities are eliminated. Of the five strategies, two that received lower ratings are “. . . advise my students about career opportunities" $($ Mean $=2.74)$ and "... invite my students to attend professional meetings or other events" (Mean $=2.04)$.

Studies indicate that instructor immediacy behaviors are strongly correlated with student learning outcomes (Arbaugh \& Benbunan-Fich, 2005). Immediacy is a well defined construct in instructional communication discipline (Hutchins, 2003). Immediacy refers to behaviors that reduce social and psychological distance between people (Arbaugh, 2001). It includes verbal and nonverbal behaviors. While Internet technology severely limited the instructor demonstration of the nonverbal immediacy, verbal immediacy is still possible. An instructor teaching over the Internet can still "use humor, encourage discussion and feedback, or address students by name" (Arbaugh, 2001, p. 44). 
Social presence, a sub-area of communication theory, assumes that a critical factor of a communication medium is its social presence, which is defined as the degree of salience of the other person in the interaction and the consequent salience of the interpersonal relationships (Short, Williams, \& Christie, 1976). Social presence is interpreted as the degree to which a person is perceived as "real" in mediated communication (Swan, 2003). In spite of the particular characteristics of the Internet, student perceptions of the social and human qualities of online education depend on the social presence created by the instructors and the online community (Gunawardena \& Zittle, 1997). An instructor should maintain positive interpersonal relationships with his/her distance students (White, 2000). Bischoff (2000) suggested that an online instructor communicate presence by providing regular feedback, maintaining public course visibility, and selecting and directing student to high quality learning materials.

\section{Online Compared to Face-to-Face}

Kausler (2004) conducted a research involving 192 participants from community colleges, baccalaureate institutions, and research/doctoral institutions. She explored how instructors at different types of higher education institutions differ in their use of instructional strategies. Her study indicated that "there was a significant main effect between the types of institutions on the seven principles ... [but] the difference was weak and subtle" (2004, p.79). Ratings from her study (fact-to-face) are presented in Table 34 along with the ratings from the present study. 
Table 34

Online versus Face-to-Face Implementation

\begin{tabular}{llcc}
\hline \multirow{2}{*}{ Principles } & \multicolumn{2}{c}{ Mean } \\
\cline { 2 - 3 } & & Online & Face-to-Face $^{\mathrm{a}}$ \\
\hline 1. Encourage Student-Faculty Contact & 3.11 & 2.63 \\
2. Encourage Cooperation Among Students & 2.98 & 3.20 \\
3. Encourage Active Learning & 3.60 & 2.73 \\
4. Give Prompt Feedback & 4.03 & 3.47 \\
5. Emphasize Time on Task & 4.06 & 3.68 \\
6. Communicate High Expectations & 4.32 & 3.97 \\
7. Respect Diverse Talents and Ways of Learning & 3.75 & 3.14 \\
\hline
\end{tabular}

Note. ${ }^{\mathrm{a}}$ Kausler (2004, p. 72)

In comparison with other principles, Principle 6 scored highest in the face-to-face instruction, just as it did in this online study (see Table 34). This greater emphasis on Principle 6 Communicate High Expectations is not coincidental. Rather, it indicates the universality of that pedagogical principle. It applies to both traditional face-to-face instruction and to distance online instruction. The ease with which the principle can be implemented may play a role as well.

Ratings from these two different studies of the implementation of the Seven Principles form a very similar pattern in trend lines. Figure 1 presents the trend lines for both face-to-face instruction (Kausler, 2004) and online instruction (current investigation). 


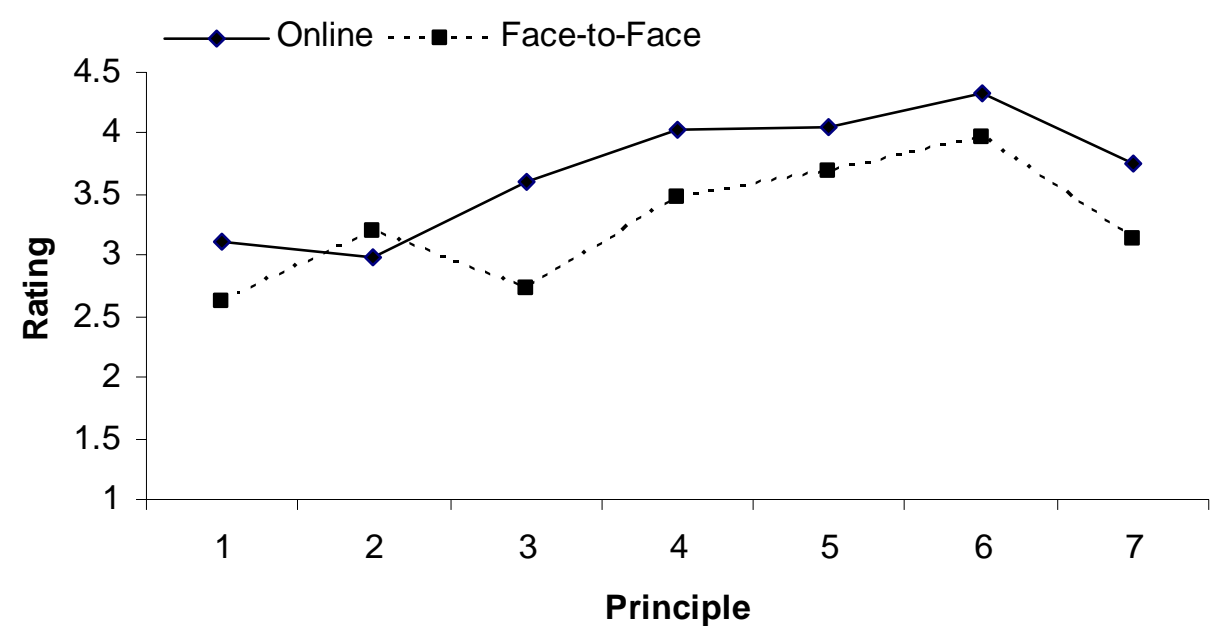

Figure 1. Online (current investigation) versus face-to-face (Kausler, 2004) implementation of the Seven Principles.

The trend lines indicate some interesting difference in the implementation of the Seven Principles. One difference lies in the fact that online instruction emphasized Principle 3 Encourage Active Learning more than conventional face-to-face instruction. In the face-to-face environment (Kausler, 2004) the average rating was Mean $=2.73$ while in current online investigation the rating was Mean $=3.60$. The different characteristics of the two instructional formats may account for the difference in the implementation of this principle. The text-base written communication provides a student with the opportunity to reflect and collect his thoughts, but in face-to-face communication an instructor set the pace of a lecture. In the online environment, a student needs "good thinking skills, an ability to work and do some amount of research independently, and an ability to work with minimal amount of structure" (Pallott \& Pratt, 2001, p. 109). But in a traditional setting, a student may chose to be a passive listener (Pallott \& Pratt, 2001) and rely on lectures and explanation from an instructor. 
Another difference lies in the implantation of Principle 2 Encourage Cooperation Among Students. Principle 2 received less emphasis in the Internet environment than in the traditional face-to-face environment. In the Web-based setting, Principle 2 was rated lower than Principle 3, 4, 5, 6, and 7. But in the conventional face-to-face setting, Principle 2 received a rating that was higher than both Principles 1 and 3 . If the difference really exists, online instructors' concern over academic dishonesty at the distance may serve as an explanation here. In the face-to-face scenario, an instructor usually relies on different communication channels to check on the students and makes sure a student is studying. The electronic environment makes an instructor less sure about the work a student turns in, and there are calls for more attentions about the problem of dishonesty in online assessment (Rowe, 2004). This explains why some instructors teaching online courses do not encourage cooperation in their distance online courses.

Winegar (2000) conducted a study about online instructors' attitudes toward the Seven Principles. In all, 52 online instructors teaching graduate or undergraduate level courses participated. The study indicated that although online instructors had "positive attitudes toward all of the principles" (p. 60), developing cooperation among students "received least favorable responses" (p. 60). Winegar's findings of the online instructor attitude toward the Seven Principles are presented in Attitude column in Table 35 along with the rating from the present study. 
Table 35

Online Practice versus Attitude

\begin{tabular}{llcc}
\hline \multicolumn{1}{c}{ Principles } & \multicolumn{2}{c}{ Mean } \\
\cline { 2 - 3 } & & Practice & Attitude $^{\mathrm{a}}$ \\
\hline 1. Encourage Student-Faculty Contact & 3.11 & 4.21 \\
2. Encourage Cooperation Among Students & 2.98 & 3.50 \\
3. Encourage Active Learning & 3.60 & 4.15 \\
4. Give Prompt Feedback & 4.03 & 4.21 \\
5. Emphasize Time on Task & 4.06 & 3.85 \\
6. Communicate High Expectations & 4.32 & 3.82 \\
7. Respect Diverse Talents and Ways of Learning & 3.75 & 3.74 \\
\hline
\end{tabular}

Note. ${ }^{\text {a } W i n e g a r ~(2000, ~ p . ~ 44) . ~ I n ~ W i n e g a r ' s ~ 5-p o i n t ~ L i k e r t ~ s c a l e, ~} 1=$ Very Negative, $2=$ Negative, $3=$ Neutral, $4=$ Positive, and $5=$ Very Positive.

Without a statistical comparison, no conclusion can be made as whether or not there does exist a significant difference in the implementation of Principle 2 Encourage Cooperation Among Students between the two instructional media (online versus face-toface). Nevertheless, both Winegar (2000) (online environment) and the present study (online environment) found "Encourage Cooperation Among Students" (Principle 2) to be rated low (see Figure 2). In contrast, the study by Kausler (2004) found Principle 2 to be relatively strongly endorsed by instructors in the face-to-face environment. 


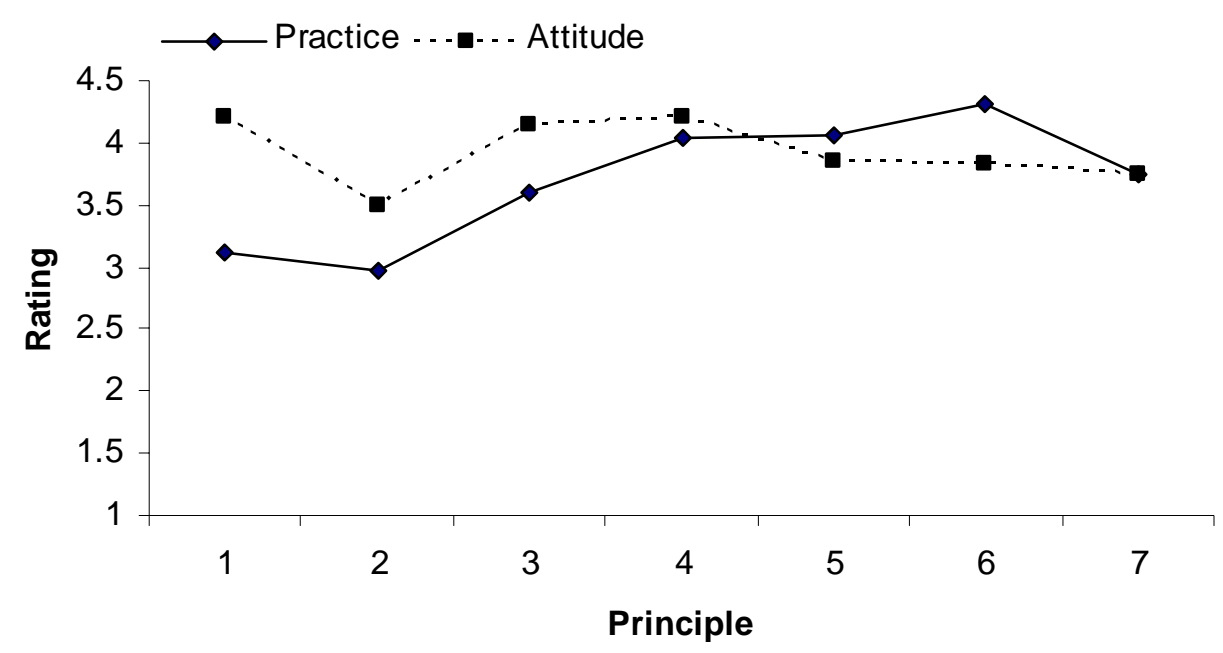

Figure 2. Ratings for Principle 2 are low for both instructor attitude (Winegar, 2000) and practice (current investigation).

\section{Positive and Negative Categories}

The top four positive categories identified from Research Question 2 include (1)

Instructional Strategies, (2) Technology Features, (3) Accessibility \& Availability, and (4) Rules \& Encouragement. These four categories are determined from the overall responses from across the Seven Principles. Some of these positive categories appeared multiple times from participant responses others appeared less frequently.

With regard to Positive Category 1 Instructional Strategies, participants reported to have required students to engage in "interactive discussion," contact each other, "work on projects together," and to incorporate instructor feedback. Other participants attempted to "expose student to diversity in race, political thoughts, and media," comment on “papers, quizzes, and assignment," and give "fast turnaround for grades on weekly assignment." One participant commented:

I have designed tutorials so that students submit photo assignments in Web galleries, so that their assignments are immediately available for 
critique by classmates ... I usually wait a few days to weigh in myself and grade the assignments so that students feel free to make comments without my "authoritative" opinion. I also try to follow-up on weekly discussion questions once every 24 hours.

Teaching over the Internet requires an instructor to move beyond traditional models of pedagogy into new practices that are more facilitative (Palloff \& Pratt, 2001). One participant noted he graded assignments as fast as possible, wrote e-mails when he saw a problem immediately and gave them a second chance, and respond to their e-mails as soon as he received them.

With regard to Positive Category 2 Technology Features, participants reported features such as e-mails, synchronous chat discussions, discussion boards, interactive lessons, and automatic grading for exams were useful for the implementation of the Seven Principles. Others believed that the course setup and the ability to sort and organize assignments in an electronic version were helpful.

With regard to Positive Category 3 Accessibility \& Availability, many participants emphasized the importance of frequent communication with the student to give them "a sense of connection." Being accessible and available to the students includes providing online office hours, phone advising appointments, or synchronous chat discussions. Instructors often encouraged the students to e-mail or call the instructors for any problems or questions they encountered. Some instructors distributed both their office and home phone numbers to the students. Others emphasized the importance of "speedy reply" to student e-mails within 24 hours and prompt "turnaround for grades." One participant noted:

I check e-mail and the discussion board every day. I respond even when a response is not necessary. I repeated the phrase - "If you have a problem I want to know about it." I provide contact numbers beyond the 
WVU office. I encourage the students to call me if they need me and email is not fast enough.

Instructor accessibility and availability gives the students a sense of being connected in the online classroom environment (Bischoff, 2000). One participant commented that he found "students tend to care more about an online class and do better in such a class when they know a 'real' person is behind the class and ready to help them if they need it." Bischoff (2000) noted that to be electronically "visible" to the students is one of the keys for an effective online instructor. She further argued that being visible benefited students in that the constant presence of an instructor assured the students of their progress, modeled how the discussion-based instructional model worked, and removed the sense of isolation that online students often encountered. In addition to being visible to the class, instructor accessibility and availability provides a venue for students to interact.

With regard to Positive Category 4 Rules \& Encouragement, many participants reported that they believed the use of deadline and the ability to enforce a rule helped. Others reported that they made use of e-mail messages or their course calendars in WebCT Vista ${ }^{\mathrm{TM}}$ to remind the student of an up-coming due assignment.

The top four negative categories identified for Research Question 2 include (1) Time \& Distance, (2) Lack of Student Involvement, (3) Motivation \& Negligence, and (4) Technology Competence/Technical Difficulties/Technology. These four categories are determined from the overall responses from across the Seven Principles. Some of these negative categories appeared multiple times from participant responses, and others appeared less frequently. Time, technology competence, and technical support were mentioned in the Winegar (2000) study. 
With regard to Negative Category 1 Time \& Distance, some participants noted that online instruction was so time consuming that it became "a 24/7 job." Studies indicated that online teaching requires more time (McKenzie, Mims, Bennett, \& Waugh, 2000) and work (Vrasidas \& McIsaac, 2000) from the instructors. When an instructor teaches online, he/she spends more time preparing the course, replying to student e-mail messages, or simply getting the materials organized. Some participants noted that "students enrolled in the Web class had families and jobs and were too busy and lived too far away to come to campus. Time was limited [for them as well]."

Internet technology serves as an extension of traditional classroom instruction (Partee, 2002), and this extension of instruction enables students to learn at a distance without the inconvenience of traveling to campus (Beard \& Harper, 2002). However, human beings need direct personal contact and direct interpersonal interactions to communicate values. Technology cannot "duplicate the richness of direct human interactions" (Partee, 2002). Some participants noted that "lack of personal and visual contact" was a problem for online instruction. In a study, McKenzie et al. (2000) found overwhelming majority of the online instructors believed face-to-face meetings were helpful for online instruction. The same study also indicated instructor preference for a combination of face-to-face and online instruction. That probably explains why instructors so strongly felt the inconvenience of the geographic distance in the implementation of the Seven Principles.

With regard to Negative Category 2 Lack of Student Involvement, participants noted that "reticence of students" made the interaction difficult. Many participants argued that lack of student participation was a problem for online instruction. Students who do 
not participate in discussions or chats usually "miss the opportunity to interact with other students" and make it difficult for an instructor to conduct a class. One participant commented:

Some students just do not participate on the discussion boards or in the peer groups. Most of the time I do not know if it is by choice, or if they are planning to drop the class. Either way, it is the participating students that wind up getting shorted because they don't have a partner.

With regard to Negative Category 3 Motivation \& Negligence, some participants commented that some students are "willing to get by with just doing the minimum." In some cases, this category overlaps with Negative Category 2 Lack of Student Involvement. One participant noted:

The major factor that hinders implementation of student-faculty contact is the lack of response from the student. The contact depends on their motivation to follow through with correspondence. I usually make the initial contact and either the student will respond or they will not respond depending on their level of motivation and responsibility for following through on activities.

To get the student motivated may be considered as the work of an instructor. But in online distance instruction, instructors at one end of the Internet feel helpless with the student if the student does not have motivation for study. One explanation for this student involvement, motivation, and negligence problem is that students in the online environment are usually non-traditional students and consequently have "other demand on their time" (Tricker et al., 2001, p. 166). It may not be a problem of motivation or negligence, but just a matter of how much time they have for the online courses they are taking. 
With regard to Negative Category 4 Technology Competence/Technical Difficulties, participants noted that technology competence and technical difficulties could occur for both instructors and students. Although the overall technology competence of high school graduates is improving, there are some less technologically comfortable students studying through distance online courses. One participant commented that "a lot of the students do not know how to use the technology available to them." Students do not always "understand how to use the tool effectively." Participants also noted that "computer problems" or "technical problem with the Web site" caused "delay and extra time to complete quizzes." Technical problems also made it difficult for individual students to "file work on time." Technical difficulties like lack of system reliability, lack of connectivity, inadequate technical support, inadequate hardware/software, or setup problems do happen at one time or another. Online students must establish comfort with the technology and comfort with Internet-based communication before learning can occur. How to make the technology transparent and remove the technology factor remains an issue for all parties involved in the practice of online distance education.

\section{Limitations and Recommendations}

Although extensive precautions were taken in the conduct of this research, there are potential limitations. First, the study used an expert panel to evaluate content validity, and expert feedback may have elements of subjectivity (Rubio et al., 2003). Second, the study relied on participants' truthful and accurate report about their professional practice, and any deceit or bias in responding to the items of the Online Faculty Inventory may hamper the result. Third, accurate interpretation of the participant's responses to the 
open-ended questions was required. In addition, this study used a limited convenience sample of participants who taught undergraduate online classes hosted at West Virginia University in 2005 , and consequently, generalizability may be limited.

In future research, an investigation may consider the use of a student survey of their instructor's competence and practices. Such an evaluation of "how good" the instructor is could be compared to his or her ratings in the Online Faculty Inventory.

For a survey study, telephone follow-ups would make personal contact and may be used to increase response rate. Another strategy for increasing the response rate may be to visit the office of each non-respondent.

Further research might include participants from more institutions and more types of institutions so as to increase diversity of participants and increase sample size of the study. Although this study obtained a response rate of $45.79 \%$, the absolute number of the participants remained relatively limited. To invite a larger, more diverse sample to participate would increase the generalizability of the research.

Further research might include whether there exists a difference between onsite and online instruction in encouraging student cooperation. How can Encouraging Cooperation Among Students be accepted by online instructors?

\section{Conclusion}

Undergraduate online instructors indicated that they implemented five of the Seven Principles in the "Often" range (Principle 3 Encourage Active Learning, Principle 4 Give Prompt Feedback, Principle 5 Emphasize Time on Task, Principle 6 Communicate High Expectations, and Principle 7 Respect Diverse Talents and Ways of Learning). These five principles may be recommended based on both the literature review and the 
current findings. The other two principles were implemented in the "Occasionally" range (Principle 1 Encourage Student-Faculty Contact and Principle 2 Encourage Cooperation Among Students). Previous discussion has addressed possible ways to implement these two principles to the advantage of instruction and learning. Also, the literature would support these two. Thus overall recommendation may be advanced for incorporation of Chickering and Gamson's Seven Principles for Good Practice in Undergraduate Education as adapted to the online environment (Online Faculty Inventory).

This research examined potential diversity in the implementation of the Seven Principles. The results indicate that participants' self-reported ratings were consistent across Class Size, Instructor Age, Gender, Teaching Experience, Online Teaching Experience, On-Campus Face-To-Face Instruction, Highest Degree Obtained, and Instructor Job Classification. Participants teaching Humanities were more likely to endorse Encourage Active Learning than those teaching Science \& Technology. Overall the least endorsed of the Seven Principles were Encourage Cooperation Among Students and Encourage Student-Faculty Contact. In contrast, the most endorsed of the Seven Principles were Communicate High Expectations, Emphasize Time on Task, and Give Prompt Feedback. These findings contribute to understanding both (a) the positives and negatives of teaching undergraduate-online courses and (b) contrasts with findings from existing research on face-to-face implantation of the Seven Principles for Good Practice in Undergraduate Education. 


\section{REFERENCES}

Alavi, M. (2005). Technology-mediated collaborative learning: A research perspective. In S. R. Hiltz \& R. Goldman (Eds.), Learning together online: Research on asynchronous learning networks (pp. 191-213). Mahwah, NJ: Lawrence Erlbaum Associates.

Allen, I. E., \& Seaman, J. (2003, September). Sizing the opportunity: The quality and extent of online education in the United States, 2002 and 2003. Retrieved April 24, 2004, from the Sloan Consortium Web site: http://www.sloanc.org/resources/sizing_opportunity.pdf

Allen, I. E., \& Seaman, J. (2004, November). Entering the mainstream: The quality and extent of online education in the United States, 2003 and 2004. Retrieved April 11, 2005, from the Sloan Consortium Web site: http://www.sloanc.org/resources/entering_mainstream.pdf

Allen, M., Bourhis, J., Burrell, N., \& Mabry, E. (2002). Comparing student satisfaction with distance education to traditional classrooms in higher education: A metaanalysis. The American Journal of Distance Education, 16(2), 83-97.

Allen, M., Mabry, E., Mattrey, M., Bourhuis, J., Titsworth, S., \& Burrell, N. (2004). Evaluating the effectiveness of distance learning: A comparison using metaanalysis. Journal of Communication, 54(3), 402-420.

Alrajeh, N., \& Janco, B. (1998). A model for asynchronous learning networks in medical education. Asynchronous Learning Networks Magazine, 2(2). Retrieved February 8, 2005, from http://www.aln.org/publications/magazine 
Anderson, T., Rourke, L., Garrison, D. R., \& Archer, W. (2001). Assessing teaching presence in a computer conferencing context. Journal of Asynchronous Learning Networks, 5(2), 1-17. Retrieved February 8, 2005, from http://www.aln.org/publications/jaln

Arbaugh, J. B. (2001). How instructor immediacy behaviors affect student satisfaction and learning in Web-based course. Business Communication Quarterly, 64(4), 4254.

Arbaugh, J. B., \& Benbunan-Fich, R. (2005). Contextual factors that influence ALN effectiveness. In S. R. Hiltz \& R. Goldman (Eds.), Learning together online: Research on asynchronous learning networks (pp. 123-144). Mahwah, NJ: Lawrence Erlbaum Associates.

Bates, A. W. (1997, June). Restructuring the university for technological change. Paper presented at the conference of the Carnegie Foundation for the Advancement of Teaching: What Kind of University? London, UK. Retrieved March 7, 2005, from http://bates.cstudies.ubc.ca/carnegie/carnegie.html

Beard, L. A., \& Harper, C. (2002). Student perceptions of online versus on campus instruction. Education, 122(4), 658-663.

Benbunan-Fich, R., Hiltz, S. R., \& Harasim, L. (2005). The online interaction learning model: An integrated theoretical framework for learning networks. In S. R. Hiltz \& R. Goldman (Eds.), Learning together online: Research on asynchronous learning networks (pp. 19-37). Mahwah, NJ: Lawrence Erlbaum Associates.

Benjamin, E. (2002). How over-reliance on contingent appointments diminishes faculty involvement in student learning [Electronic version]. Peer Review, 5(1), 4-10. 
Retrieved October 31, 2005 from the Association of American Colleges and Universities Web site: http://www.aacu.org/peerreview/pdfs/pr-fa02feature1.pdf

Berdie, D. R., Anderson, J. F., \& Niebuhr, M. A. (1986). Questionnaires: Design and use. (2nd ed.). Metuchen, NJ: Scarecrow Press.

Bischoff, A. (2000). The elements of effective online teaching: Overcoming the barriers to success. In K. W. White \& B. H. Weight (Eds.), The online teaching guide: A handbook of attitudes, strategies, and techniques for the virtual classroom (pp. 57-72). Boston, MA: Allyn and Bacon.

Boyd, R. D., \& Apps, J. W. (1980). A conceptual model for adult education. In R. D. Boyd \& J.W. Apps (Eds.), Redefining the discipline of adult education (pp. 1-31). San Francisco, LA: Jossey-Bass.

Brown, B. W., \& Liedholm, C. E. (2002). Can Web courses replace the classroom in principles of microeconomics? The American Economic Review, 92(2), 444-448.

Burgoon, J., Buller, D., \& Woodall, W. (1996). Nonverbal communication: The unspoken dialogue (2nd ed.). New York: McGraw-Hill.

Carnevale, D. (2004). Many online courses work best at no distance at all. Chronicle of Higher Education, 50(47), A22.

Carr, S. (2000). As distance education comes of age, the challenge is keeping the students. Chronicle of Higher Education 46(23), A39.

Chickering, A. W., \& Ehrmann, S. C. (1996, October). Implementing the seven principles: Technology as lever. AAHE Bulletin, 48(2), 3-6. Retrieved June 2, 2005, from http://www.tltgroup.org/programs/seven.html 
Chickering, A. W., \& Gamson, Z. F. (1987, March). Seven principles for good practice in undergraduate education. AAHE Bulletin, 39(7), 3-7. Retrieved April 25, 2004, from http://aahebulletin.com/public/archive/sevenprinciples1987.asp.

Chickering, A. W., \& Gamson, Z. F. (1999). Development and adaptations of the Seven Principles for Good Practice in Undergraduate Education. New Directions for Teaching \& Learning, 80, 75-81.

Chickering, A. W., Gamson, Z. F., \& Barsi, L. M. (1989). Faculty inventory: Seven principles for good practice in undergraduate education. Racine, WI: The Johnson Foundation.

Clark, R. E. (1983). Reconsidering research on learning from media. Review of Educational Research, 53(4), 445-459.

Clark, R. E. (1994). Media will never influence learning. Educational Technology Research and Development, 42(2), 21-29.

Conrad, D. (2004). University instructors' reflections on their first online teaching experiences. Journal of Asynchronous Learning Networks, 8(2), 31-44. Retrieved February 7, 2005, from http://www.aln.org/publications/jaln

Davis, L. (1992). Instrument review: Getting the most from a panel of experts. Applied Nursing Research, 5, 194-197.

Ehrmann, S. C. (1995). Asking the right questions. Change, 27(2), 20-28.

Fallah, M. H., \& Ubell, R. (2000). Blind scores in a graduate test: Conventional compared with Web-based outcomes. ALN Magazine, 4(2). Retrieved March 7, 2005, from http://www.aln.org/publications/magazine/v4n2/fallah.asp 
Flowers, D. J. (2002). Utilization-focused needs assessment: A case study of adult learners' Web-based distance education needs. Dissertation Abstracts International, 61(6), 2143A. (UMI No. 9975867)

Flowers, J. (2001). Online learning needs in technology education. Journal of Technology Education, 13(1), 17-30.

Gamson, Z. F. (1991). A brief history of the Seven Principles for Good Practice in Undergraduate Education. In A. W. Chickering \& Z. F. Gamson (Eds.), Applying the seven principles for good practice in undergraduate education (pp. 5-12). San Francisco, LA: Jossey-Bass.

Gamson, Z. F. (1995). The seven principles for good practice in undergraduate education: A historical perspective. In S. R. Hatfield (Ed.), The Seven Principles in action: Improving undergraduate education (pp. 1-8). Bolton, MA: Anker Publishing.

Garrison, D. R., Anderson, T., \& Archer, W. (2000). Critical inquiry in a text-based environment: Computer conferencing in higher education. The Internet and Higher Education 2(2-3), 87-105.

Garrison, D. R., Cleveland-Innes, M., \& Fung, T. (2004). Student role adjustment in online communities of inquiry: Model and instrument validation. Journal of Asynchronous Learning Networks, 8(2), 61-74. Retrieved February 8, 2005, from http://www.aln.org/publications/jaln

Graham, C., Cagiltay, K., Lim, B., Craner, J., \& Duffy, T. M. (2001, March/April). Seven principles of effective teaching: A practical lens for evaluating online courses. The Technology Source. Retrieved March 2, 2005 from http://ts.mivu.org/default.asp?show $=$ article\&id $=839$ 
Grant, J. S., \& Davis, L. L. (1997). Selection and use of content experts for instrument development. Research in Nursing \& Health, 20, 269-274.

Gunawardena, C. N., \& Zittle, F. J., (1997). Social presence as a predictor of satisfaction within a computer mediated conferencing environment. The American Journal of Distance Education, 11(3), 8-26.

Hatfield, T., \& Hatfield, S. R. (1995). Cooperative learning communities. In S. R. Hatfield, D. G. Brown, D. W. Krueger, S. J. Poulsen, R. A. Scott, \& M. Nemko (Eds.), The Seven Principles in action: Improving undergraduate education (pp. 23-38). Bolton, MA: Anker Publishing Company.

Hewitt, J. (2003). How habitual online practices affect the development of asynchronous discussion threads. Journal of Educational Computing Research, 28(1), 31-45. Higher Education Research Center. (2001, March). Focus on distance education. Update 7(2). Retrieved March 19, 2004, from http://www.nea.org/he/heupdate/vol7no2.pdf

Howell, S. L., Laws, R. D., \& Lindsay, N. K. (2004). Reevaluating course completion in distance education: Avoiding the comparison between apples and oranges. The Quarterly Review of Distance Education, 5(4), 243-252.

Hutchins, H. M. (2003). Instructional immediacy and the Seven Principles: Strategies for facilitating online courses. Online Journal of Distance Learning Administration, 6(3). Retrieved November 14, 2005, from http://www.westga.edu/ distance/ojdla/fall63/hutchins63.html 
Institute for Higher Education Policy. (2000). Quality on the line: Benchmarks for success in Internet-based distance education. Retrieved March 10, 2004 from http://www.nea.org/he/abouthe/Quality.pdf

Jonassen, D. H. (2002). Engaging supporting problem solving in online learning. Quarterly Review of Distance Education, 3(1), 1-13.

Jonassen, D. H., Dyer, D., Peters, K., Robinson, T., Harvey, D., King, M., et al. (1997). Cognitive flexibility hypertexts on the Web: Engaging learners in meaning making. In B. H. Khan (Ed.), Web-based instruction (pp. 119-133). Englewood Cliff, NJ: Educational Technology Publications.

Kausler, D. A. (2004). College Professors' Use of Motivational Strategies. Dissertation Abstracts International, 65(3), 829A. (UMI No. 3126985)

Keeton, M. T. (2004). Best online instructional practice: Report of phase I on an ongoing study. Journal of Asynchronous Learning Networks, 8(2), 75-100. Retrieved July 4, 2005, from http://www.aln.org/publications/jaln/v8n2/v8n2_keeton.asp

Khan, B. H. (1997). Web-based instruction (WBI): What is it and why is it? In B. H. Khan (Ed.), Web-based instruction (pp. 5-18). Englewood Cliffs, NJ: Educational Technology Publications.

Kincaid, S. O. (2003). Web-based courses in human services: A comparison of student and faculty perceptions of factors that facilitate or hinder learning. Dissertation Abstracts International, 64(7), 2403A. (UMI No. 3098041)

Knowles, M. S., Holton, E. F., III, \& Swanson, R. A. (2005). The adult learner: The definitive classic in adult education and human resource development. Boston, MA: Elsevier. 
Kozma, R. B. (1991). Learning with media. Review of Educational Research, 61(2), 179211.

Kuh, G. D., Kinzie, J., Schuh, J. H., Whitt, E. J., \& Associates. (2005). Student success in college: Creating conditions that matter. San Francisco, CA: Jossey-Bass.

Lanza, A., \& Roselli, T. (1991). Effects of the hypertextual approach versus the structured approach on students' achievement. Journal of Computer-Based Instruction, 18(2), 48-50.

Lewis, L., Snow, K., Farris, E., Levin, D., \& Greene, B. (1999). Distance education at postsecondary education institutions: 1997-98 (Publication No. NCES 2000-013). Washington, DC: U.S. Department of Education. Retrieved March 19, 2004, from http://nces.ed.gov/pubs2000/2000013.pdf

Lilja, D. J. (2001). Comparing instructional delivery methods for teaching computer systems performance analysis. IEEE Transactions on Education, 44(1), 35-40.

Lynch, T. (2002). LSU expands distance learning program through online learning solution. T.H.E. Journal 29(6), 47-48.

Lynn, M. (1986). Determination and quantification of content validity. Nursing Research, $35,382-385$.

Matthews, D. (1999). The Origins of Distance Education and Its Use in the United States. T.H.E. Journal, 27(2), 54. Retrieved May 24, 2005, from http://www.thejournal.com/magazine/vault/A2222.cfm

McAlister, S. Ravenscroft, A., \& Scanlon, E. (2004). Combining interaction and context design to support collaborative argumentation using a tool for synchronous CMC. Journal of Computer Assisted Leaning, 20, 194-204. 
McKenzie, B. K., Mims, N., Bennett, E., \& Waugh, M. (2000). Needs, concerns and practices of online instructors. Online Journal of Distance Learning Administration, 3(3). Retrieved October 31, 2005, from http://www.westga.edu/ distance/ojdla/fall33/mckenzie33.html

Merisotis, J. P., \& Phipps, R. A. (1999). What's the difference? Outcomes of distance vs. traditional classroom-based learning. Change, 31(3), 12-17.

Miller, S. M., \& Miller, K. L. (2000). Theoretical and practical considerations in the design of Web-based instruction. In B. Abbey (Ed.), Instructional and cognitive impacts of Web-based education (pp. 156-173). Hershey, PA: Idea Group.

Moore, M. G. (1972). Learner autonomy: The second dimension of independent learning. Convergence, 5(2), 76-88.

Moore, M. G. (1980). Independent study. In R. D. Boyd \& J.W. Apps (Eds.), Redefining the discipline of adult education (pp. 16-31). San Francisco, LA: Jossey-Bass.

Moore, M. G. (1986). Self-directed learning and distance education. Journal of Distance Education, 1(1), 7-24.

Moore, M. G. (1989). Three types of interaction. The American Journal of Distance Education, 3(2), 1-6.

Moore, M. G. (1991). Distance education theory. The American Journal of Distance Education, 5(3), 1-6.

Moore, M. G., \& Kearsley, G. (2005). Distance education: A systems view (2nd ed.). Belmont, CA: Wadsworth.

Neuhauser, C. (2002). Learning style and effectiveness of online and face-to-face instruction. American Journal of Distance Education 16(2), 99-113. 
Newlin, M. H., \& Wang, A. Y. (2002). Integrating technology and pedagogy: Web instruction and Seven Principles of Undergraduate Education. Teaching of Psychology, 29(4), 325-30.

Oberst, J. E. (1995). Seven principles student inventory: An indicator of success? Dissertation Abstracts International, 56 (09), 3400A. (UMI No. 9544938)

Palloff, R. M., \& Pratt, K., (2001). Lessons from the cyberspace classroom: The realities of online teaching. San Francisco, CA: Jossey-Bass.

Partee, M. H. (2002). Cyberteaching: Instructional technology on the modern campus. Lanham, MD: University Press of America.

Phipps, R., \& Merisotis, J. (1999, April). What's the difference: A review of contemporary research on the effectiveness of distance learning in higher education. Washington, DC: Institute for Higher Education Policy.

Regalbuto, J. (1999, December 7). Teaching at an Internet distance: The pedagogy of online teaching and learning: The report of a 1998-1999 University of Illinois faculty seminar. Retrieved March 4, 2005, from University of Illinois Web site: http://www.vpaa.uillinois.edu/reports_retreats/tid_final-12-5.pdf

Ritter, M. E., \& Lemke, K. A. (2000). Addressing the "Seven Principles for Good Practice in Undergraduate Education" with Internet-enhanced education. Journal of Geography in Higher Education, 24(1), 100-108.

Rowe, N. C. (2004). Cheating in online student assessment: Beyond plagiarism. Online Journal of Distance Learning Administration, 7(2). Retrieved November 14, 2005, from http://www.westga.edu/ distance/ojdla/summer72/rowe72.html 
Rubio, D. M., Berg-Weger, M., Tebb, S. S. Lee, E. S., \& Rauch, S. (2003). Objectifying content validity: Conducting a content validity study in social work research. Social Work Research, 27(2), 94-105.

Russell, T. L. (1997). The "no significant difference" phenomenon as reported in 248 research reports, summaries, and papers (4th ed.). Raleigh, NC: North Carolina State University.

Schrum, L., \& Berenfeld, B. (1997). Teaching and learning in the information age: A guide to educational telecommunications. Needham Heights, MA: Allyn \& Bacon.

Scott, B. (2002). The pedagogy of on-line learning: A report from the University of the Highlands and Islands Millennium Institute. Information Science \& Use, 22(1), $19-26$.

Scott, R. A., \& Tobe, D. E. (1995). Effective undergraduate education communicates high expectations. In S. R. Hatfield, D. G. Brown, D. W. Krueger, S. J. Poulsen, R. A. Scott, \& M. Nemko (Eds.), The Seven Principles in action: Improving undergraduate education (pp. 79-94). Bolton, MA: Anker Publishing Company.

Shachar, M. (2002). Differences between traditional and distance learning outcomes: A meta-analytic approach. Dissertation Abstracts International, 63(10) 3465A.

Short, J. A., Williams, E., \& Christie, B. (1976). The social psychology of telecommunications. New York, NY: John Wiley \& Sons.

Sikora, A. C., \& Carroll, C. D (2002). A profile of participation in distance education: 1999-2000 (Publication No. NCES 2003-154). Washington, DC: U.S. Department of Education. Retrieved September 11, 2004, from http://nces.ed.gov/pubs2003/2003154.pdf 
Snyder, T. D., Tan, A. G., \& Hoffman, C. M. (2003). Digest of education statistics, 2003. (Publication No. NCES 2005025). Washington, DC: U.S. Department of Education. Retrieved April 11, 2005, from http://nces.ed.gov/pubsearch/pubsinfo.asp?pubid=2005025

Sorcinelli, M. D. (1991). Research findings on the Seven Principles. In A. W. Chickering \& Z. F. Gamson (Eds.), Applying the Seven Principles for Good Practice in Undergraduate Education (pp. 5-12). San Francisco, LA: Jossey-Bass.

Swan, K. (2003). Developing social presence in online discussions. In S. Naidu (Ed.), Learning and teaching with technology: Principles and practices (pp. 147-164). London, UK: Kogan.

Swan, K. (2004, March). Issues of interface. Paper presented at the Third EDEN Research Workshop and International Conference, Oldenburg, Germany.

Taylor, A. G. (2000). Wynar's introduction to cataloging and classification (9th ed.). Englewood, CO: Libraries Unlimited.

Terry, N., Owens, J., \& Macy, A. (2001). Student performance in the virtual versus traditional classroom. Journal of the Academy of Business Education, 2, 1-4.

Tricker, T., Rangecroft, M., Long, P., \& Gilroy, P. (2001). Evaluating distance education courses: The student perception. Assessment and Evaluation in Higher Education, 26(2), 165-177.

Vrasidas, C., \& McIsaac, M. S. (2000). Principles of pedagogy and evaluation for Webbased learning. Education Media International, 37(2), 105-111.

Waits, T., \& Lewis, L. (2003). Distance education at degree-granting postsecondary institutions: 2000-2001 (Publication No. NCES-2003-017). Washington, DC: U.S. 
Department of Education. Retrieved June 22, 2005, from http://nces.ed.gov/pubs2003/2003017.pdf

Weiner, R. S. (2000, June 21). Instructors say online courses involve more work at same pay. The New York Times on the Web. Retrieved October 31, 2005, from http://partners.nytimes.com/library/tech/00/06/cyber/education/21 education.html

White, K. (2000). Face to face in the online classroom: Keeping it interpersonal and human. In K. W. White \& B. H. Weight (Eds.), The online teaching guide: A handbook of attitudes, strategies, and techniques for the virtual classroom (pp. 57-72). Boston, MA: Allyn and Bacon.

Williams, C. (2002). Learning on-line: A review of recent literature in a rapidly expanding field. Journal of Further and Higher Education, 26(3), 263-272.

Willis, B. (1993). Distance education: A practical guide. Englewood Cliffs, NJ: Educational Technology.

Winegar, M. L. (2000). An exploration of seven principles for good practice in Webbased courses. Dissertation Abstracts International, 61(07), 2674A. (UMI No. 9978858)

Wood, V. L. (2002). What influences selections of instructional strategies for Web-based instruction? Relationships between approaches to teaching, concerns with technology, and selections of strategies (Doctoral dissertation, University of Colorado at Denver, 2002). Dissertation Abstracts International, 63(05), 1802A. 
APPENDICES 


\section{Appendix A}

IRB Approval for the Study 
W WestVirginiaUniversity

College of Human Resources and Education

July 22, 2005

\section{MEMORANDUM}

TO:

Jinsong Zhang,$A L A$

FROM: Lynn Cartwrighth sp Interim Associate Dean

RE: $\quad$ Human Resources \& Education H.S. \#2005-058

\section{Title: “Instructors' Self-Perceived Pedagogical Principle Implementation in the Online Environment"}

Your Application for Exemption for the above-captioned research project has been reviewed under the Human Subjects Policies and has been approved. Attached is the original of your cover letter with the signed stamp of approval. This must accompany your survey or questionnaire.

This exemption will remain in effect on the condition that the research is carried out exactly as described in the application.

Best wishes for the success of your research.

cc: Deans Office 
Appendix B

Course Classification 


\section{Course Classification ${ }^{*}$}

Course classification scheme combines practicality with standard library classification methods. Although the Library of Congress Classification (LCC) provides a readily available method to group course subjects, its specificality of the classification makes it unusable for this study.

The following table maps the LCC categories into ten classes of Dewey Decimal Classification (DDC). Brown's subject classification (Taylor, 2000, p. 335) provides a basis for collapsing some categories when there are only one or two courses in a category. As there are relatively more classes in Health Science, it is separated from its superior: Science \& Technology.

\begin{tabular}{|c|c|c|c|c|c|}
\hline \multicolumn{2}{|r|}{ LCC Classes } & \multicolumn{2}{|c|}{ DDC Classes } & \multirow{3}{*}{$\begin{array}{l}\text { Research } \\
\text { Grouping }\end{array}$} & \multirow[t]{3}{*}{ Course Subject } \\
\hline$A$ & General Works & \multirow[b]{2}{*}{000} & \multirow[b]{2}{*}{ Generalities } & & \\
\hline Z & $\begin{array}{l}\text { Bibliography. Library science. } \\
\text { Information resources } \\
\text { (general) }\end{array}$ & & & & \\
\hline $\mathrm{B}$ & $\begin{array}{l}\text { Philosophy. Psychology. } \\
\text { Religion }\end{array}$ & 100 & $\begin{array}{l}\text { Philosophy \& } \\
\text { psychology }\end{array}$ & Humanities & $\begin{array}{l}\text { PHIL (Philosophy) } \\
\text { PSYC (Psychology) }\end{array}$ \\
\hline B & $\begin{array}{l}\text { Philosophy. Psychology. } \\
\text { Religion }\end{array}$ & 200 & Religion & Humanities & \\
\hline B & $\begin{array}{l}\text { Philosophy. Psychology. } \\
\text { Religion }\end{array}$ & \multirow[t]{12}{*}{300} & \multirow[t]{12}{*}{$\begin{array}{l}\text { Social } \\
\text { Sciences }\end{array}$} & \multirow[t]{12}{*}{ Humanities } & \multirow{12}{*}{$\begin{array}{l}\text { AGEE (Agricultural / Envir. Ed.) } \\
\text { BUSA (Business Administration) } \\
\text { CDFS (Child Development/ Family } \\
\text { Studies) } \\
\text { CJ (Criminal Justice) } \\
\text { ECON (Economics) } \\
\text { ENTR (Entrepreneurship) } \\
\text { F\&CS (Family \& Consumer } \\
\text { Sciences) } \\
\text { HIST (History) } \\
\text { HN\&F (Human Nutrition and Foods) } \\
\text { MDS (Multidisciplinary Studies) } \\
\text { MILS (Military Science) } \\
\text { MKTG (Marketing) } \\
\text { ORIN (Orientation) } \\
\text { POLS (Political Science) } \\
\text { PR (Public Relation) } \\
\text { SOCA (Sociology and } \\
\text { Anthropology) } \\
\text { SOWA (Social Work) } \\
\text { SPA (Speech Pathology and } \\
\text { Audiology) }\end{array}$} \\
\hline $\mathrm{D}$ & $\begin{array}{l}\text { History (general) and history } \\
\text { of Europe }\end{array}$ & & & & \\
\hline$E$ & History: America & & & & \\
\hline $\mathrm{F}$ & History: America & & & & \\
\hline G & $\begin{array}{l}\text { Geography. Anthropology. } \\
\text { Recreation }\end{array}$ & & & & \\
\hline $\mathrm{H}$ & Social sciences & & & & \\
\hline $\mathrm{J}$ & Political science & & & & \\
\hline $\mathrm{K}$ & Law & & & & \\
\hline $\mathrm{L}$ & Education & & & & \\
\hline$U$ & Military science & & & & \\
\hline V & Naval science & & & & \\
\hline W & Medical profession & & & & \\
\hline
\end{tabular}

\footnotetext{
${ }^{*}$ Note: This table was constructed with reference with materials from http://www.questionpoint.org/crs/html/help/en/ask/ask_map_lcctoddc.html
} 


\begin{tabular}{|c|c|c|c|c|c|}
\hline $\mathrm{C}$ & Auxiliary sciences of history & \multirow[t]{3}{*}{400} & \multirow[t]{3}{*}{ Language } & \multirow[t]{3}{*}{ Humanities } & \multirow{3}{*}{$\begin{array}{l}\text { ADV (Advertising) } \\
\text { COMM (Communication Studies) } \\
\text { ENGL (English) } \\
\text { JRL (Journalism) } \\
\text { N-E (News Editorial) }\end{array}$} \\
\hline $\mathrm{H}$ & Social sciences & & & & \\
\hline$P$ & Language and literature & & & & \\
\hline $\mathrm{C}$ & Auxiliary sciences of history & \multirow[t]{3}{*}{500} & \multirow{3}{*}{$\begin{array}{l}\text { Natural } \\
\text { sciences \& } \\
\text { mathematics }\end{array}$} & \multirow{3}{*}{$\begin{array}{l}\text { Science \& } \\
\text { Technology }\end{array}$} & \multirow{3}{*}{$\begin{array}{l}\text { CHEM (Chemistry) } \\
\text { GEOL (Geology) } \\
\text { MATH (Mathematics) } \\
\text { PHYS (Physics) }\end{array}$} \\
\hline G & $\begin{array}{l}\text { Geography. Anthropology. } \\
\text { Recreation }\end{array}$ & & & & \\
\hline $\mathrm{Q}$ & Science & & & & \\
\hline $\mathrm{H}$ & Social sciences & \multirow[t]{8}{*}{600} & \multirow{8}{*}{$\begin{array}{l}\text { Technology } \\
\text { (Applied } \\
\text { sciences) }\end{array}$} & \multirow{8}{*}{$\begin{array}{l}\text { Science \& } \\
\text { Technology }\end{array}$} & \multirow{8}{*}{$\begin{array}{l}\text { A\&VS (Animal and veterinary } \\
\text { Science) } \\
\text { CHPR (Community Health } \\
\text { Promotion) } \\
\text { CS (Computer Science) } \\
\text { DTHY (Dental Hygiene) } \\
\text { EXPH (Exercise Physiology) } \\
\text { MTEC (Medical Technology) } \\
\text { NBAN (Neurobiology and anatomy) } \\
\text { NSG (Nursing) } \\
\text { OTH (Occupational Therapy) } \\
\text { PCOL (Pharmacology and } \\
\text { Toxicology) } \\
\text { PLSC (Plant Science) } \\
\text { STAT (Statistics) }\end{array}$} \\
\hline $\mathrm{Q}$ & Science & & & & \\
\hline $\mathrm{S}$ & Agriculture & & & & \\
\hline $\mathrm{T}$ & Technology & & & & \\
\hline $\mathrm{R}$ & Medicine & & & & \\
\hline $\mathrm{V}$ & Naval science & & & & \\
\hline W & Medical profession & & & & \\
\hline Z & $\begin{array}{l}\text { Bibliography. Library science. } \\
\text { Information resources } \\
\text { (general) }\end{array}$ & & & & \\
\hline $\mathrm{C}$ & Auxiliary sciences of history & \multirow[t]{5}{*}{700} & \multirow{5}{*}{$\begin{array}{l}\text { The arts (Fine } \\
\text { and } \\
\text { decorative } \\
\text { arts) }\end{array}$} & \multirow[t]{5}{*}{ Humanities } & \\
\hline G & $\begin{array}{l}\text { Geography. Anthropology. } \\
\text { Recreation }\end{array}$ & & & & \\
\hline M & Music and books on music & & & & \\
\hline $\mathrm{N}$ & Fine arts & & & & \\
\hline TT & Technology & & & & \\
\hline $\mathrm{P}$ & Language and literature & 800 & literature \& & Humanities & \\
\hline $\mathrm{C}$ & Auxiliary sciences of history & \multirow[t]{5}{*}{900} & \multirow{5}{*}{$\begin{array}{l}\text { Geography \& } \\
\text { history }\end{array}$} & \multirow[t]{5}{*}{ Humanities } & \\
\hline $\mathrm{D}$ & $\begin{array}{l}\text { History (general) and history } \\
\text { of Europe }\end{array}$ & & & & \\
\hline$E$ & History: America & & & & \\
\hline $\mathrm{F}$ & History: America & & & & \\
\hline G & $\begin{array}{l}\text { Geography. Anthropology. } \\
\text { Recreation }\end{array}$ & & & & \\
\hline
\end{tabular}




\section{Appendix C}

Classes Where the Inventory Was Request to Be Completed 


\section{Classes Where the Inventory Was Requested to Be Completed}

\begin{tabular}{|c|c|c|c|}
\hline & Subject & Number & Course Title \\
\hline 1. & A\&VS & 402 & Values and Ethics \\
\hline 2. & ADV & 215 & Principles of Advertising \\
\hline 3. & ADV & 315 & Advertising Copywriting \\
\hline 4. & ADV & 403 & Advertising Media Analysis \\
\hline 5. & ADV & 451 & Direct Marketing \\
\hline 6. & ADV & 459 & Campaigns \\
\hline 7. & AGEE & 442 & Prog Devlpmt/Evalutn-Extension \\
\hline 8. & BUSA & 310 & Survey of Business Law \\
\hline 9. & BUSA & 320 & Survey of Management \\
\hline 10. & BUSA & 330 & Survey of Marketing \\
\hline 11. & BUSA & 340 & Survey of Finance \\
\hline 12. & CDFS & 110 & Families Across the Life Span \\
\hline 13. & CDFS & 211 & Infant Development \\
\hline 14. & CDFS & 316 & Child Development Practicum \\
\hline 15. & CDFS & 413 & Contmpry Issues-Family Relatns \\
\hline 16. & CDFS & 415 & Family Interaction/Communicatn \\
\hline 17. & CHEM & 234 & Organic Chemistry \\
\hline 18. & CHPR & 271 & Health In The Community \\
\hline 19. & CJ & 101 & Intro - Criminal Justice \\
\hline 20. & $\mathrm{CJ}$ & 206 & Introduction to Corrections \\
\hline 21. & CJ & 236 & Criminal Investigation \\
\hline 22. & $\mathrm{CJ}$ & 240 & Adjudication Process \\
\hline 23. & COMM & 303 & Business and Professional Comm \\
\hline 24. & COMM & 493Q & SPTP:Introduction to Business \\
\hline 25. & COMM & 494E & Sem:Computer Mediated Communic \\
\hline 26. & CS & 101 & Intro-Computer Applications \\
\hline 27. & CS & 220 & Discrete Mathematics \\
\hline 28. & DTHY & 100 & Health Care Terminology \\
\hline 29. & DTHY & 378 & Dental Hyg Teachng Methd \\
\hline 30. & DTHY & 478 & Clinical Evaluation \\
\hline 31. & ECON & 201 & Principles of Microeconomics \\
\hline 32. & ECON & 202 & Principles of Macroeconomics \\
\hline 33. & ENGL & 101 & Composition And Rhetoric \\
\hline 34. & ENGL & 102 & Composition And Rhetoric \\
\hline 35. & ENGL & 302 & Editing \\
\hline 36. & ENGL & 304 & Business/Professional Writing \\
\hline 37. & ENGL & 305 & Scientific \& Technical Writing \\
\hline 38. & ENGL & 305 & Technical Writing \\
\hline 39. & ENTR & $493 \mathrm{~A}$ & SPTP: Small Business Entrprnshp \\
\hline
\end{tabular}




\begin{tabular}{|c|c|c|c|}
\hline 40. & EXPH & 365 & Exercise Physiology 1 \\
\hline 41. & F\&CS & 493R & SPTP:Nutrition Pathways \\
\hline 42. & F\&CS & 493T & SPTP:Journey to Health \\
\hline 43. & GEOL & 101 & Planet Earth \\
\hline 44. & GEOL & $493 N$ & SPTP:CATS Physical Geology \\
\hline 45. & HIST & 152 & Growth-American Nation to 1865 \\
\hline 46. & HIST & 153 & Making Modern Amrca:1865-Prsnt \\
\hline 47. & HIST & 250 & West Virginia \\
\hline 48. & HIST & $293 \mathrm{~V}$ & SPTP:Sacred Places \\
\hline 49. & HIST & 453 & Civil War and Reconstruction \\
\hline 50. & $H N \& F$ & 171 & Introduction to Nutrition \\
\hline 51. & $H N \& F$ & 493B & SPTP:Nutrition Pathways \\
\hline 52. & $\mathrm{JRL}$ & 101 & Intro to Mass Communication \\
\hline 53. & $\mathrm{JRL}$ & 220 & Introduction - Photojournalism \\
\hline 54. & $\mathrm{JRL}$ & 220 & Introduction to Photography \\
\hline 55. & $\mathrm{JRL}$ & 289 & Media Issues And Ethics \\
\hline 56. & MATH & 126 & College Algebra \\
\hline 57. & MATH & 128 & Plane Trigonometry \\
\hline 58. & MATH & 129 & Pre-Calculus Mathematics \\
\hline 59. & MDS & 103 & Intro to Library Research \\
\hline 60. & MDS & 212 & Introduction to Gerontology \\
\hline 61. & MDS & 293D & SPTP:Internet Literacy \\
\hline 62. & MDS & $293 M$ & SPTP:Computers in Your Future \\
\hline 63. & MDS & 293Q & SPTP:Web Design \\
\hline 64. & MILS & 494 & Seminar:U.S. Military History \\
\hline 65. & MKTG & 350 & Product \& Price Policies \\
\hline 66. & MTEC & 200 & Medical Technology Terminology \\
\hline 67. & NBAN & 205 & Introduction to Human Anatomy \\
\hline 68. & $N-E$ & 428 & Law Of The News Media \\
\hline 69. & NSG & 333 & Ethics in Nursing. \\
\hline 70. & NSG & 340 & Professional Role Transition \\
\hline 71. & NSG & 361 & Health Assessment \\
\hline 72. & NSG & 400 & Spirituality and Health \\
\hline 73. & NSG & 421 & Systm Rsponse-Physio Dysfunctn \\
\hline 74. & NSG & 423 & Leadership in Nursing \\
\hline 75. & NSG & 433 & Sem 8:Prof Role Synthesis \\
\hline 76. & NSG & 441 & Community Response HIth Promtn \\
\hline 77. & NSG & 442 & Advanced Clinical Problems \\
\hline 78. & NSG & 442 & Review Clinical Problems \\
\hline 79. & NSG & 445 & Nursing Interventions 6 \\
\hline 80. & NSG & 476 & Intro-Nursing Research \\
\hline 81. & NSG & 481 & Introduction-Cardiac Nursing \\
\hline 82. & NSG & 493L & SPTP:Spirituality and Health \\
\hline
\end{tabular}




\begin{tabular}{|c|c|c|c|}
\hline 83. & ORIN & 151 & Career-Series Plan Exploration \\
\hline 84. & ORIN & 161 & Exploring Career Options \\
\hline 35. & ORIN & 164 & Finding the First Job \\
\hline 6. & ORIN & 252 & Career Series-Job Search \\
\hline 37. & OTH & 300 & Essentials of Clinical Anatomy \\
\hline 8. & OTH & 301 & Professional Foundations \\
\hline 9. & OTH & 302 & Surv:Clin Prblm-Solv/Sci Inqry \\
\hline 0. & OTH & 303 & Functnl Movmnt Across Lifespan \\
\hline 1. & OTH & 304 & Occupational Science \\
\hline 92. & OTH & 306 & Kinesiologic Foundations \\
\hline 93. & OTH & 307 & Neurobiologic Foundations \\
\hline 94. & OTH & 308 & Evaluation Procedures \\
\hline 35. & OTH & 321 & Developmental Life Tasks \\
\hline 6. & OTH & 360 & Research Methods in OT \\
\hline 97. & OTH & 384 & Level I Fieldwork 1 \\
\hline 98. & OTH & 386 & Level I Fieldwork 3 \\
\hline 99. & OTH & 401 & Occupational Science 2 \\
\hline 100. & OTH & 408 & Tests/Measures-Occupatnl Thrpy \\
\hline 101. & OTH & 416 & Professional Decision-Making \\
\hline 102. & OTH & 417 & Occupationl Therapy-Geriatrics \\
\hline 103. & $\mathrm{OTH}$ & 419 & Professional Values \\
\hline 104. & OTH & 430 & Occupatnl Therapy-Mental HIth \\
\hline 105. & OTH & 432 & OT Interventions-Mental Health \\
\hline 106. & OTH & 435 & Therapeutic Activity \\
\hline 107. & OTH & 480 & Current Topics-Occupatnl Thrpy \\
\hline 108. & OTH & 493 & SPTP:Development Disabilities \\
\hline 109. & OTH & $493 \mathrm{~A}$ & SPTP:Cognition/Vision in OTH \\
\hline 110. & OTH & 493B & SPTP:Cardiopulmonary PBL \\
\hline 111. & OTH & 495 & Independent Study \\
\hline 112. & OTH & 497 & Research:Capstone \\
\hline 113. & PCOL & 260 & Pharmacology \\
\hline 114. & PHIL & 120 & Introduction to Ethics \\
\hline 115. & PHIL & 140 & Historical Intro to Philosophy \\
\hline 116. & PHIL & 493D & SPTP:Logic and Knowledge \\
\hline 117. & PHYS & 493G & SPTP:Modern Physics-Teachers \\
\hline 118. & PLSC & $293 C$ & SPTP:Plants-People/Past-Presnt \\
\hline 119. & POLS & 220 & State and Local Government \\
\hline 120. & POLS & 230 & Introduction Policy Analysis \\
\hline 121. & POLS & 321 & West Virginia Government \\
\hline 122 & POLS & $493 C$ & SPTP:Great Books-Amer Politics \\
\hline 123 & POLS & 493L & SPTP:Americn Federalism/Policy \\
\hline & PR & 215 & Intro To Public Relations \\
\hline 5. & PR & 324 & Public Relatns Writing/Applctn \\
\hline
\end{tabular}


126. PSYC 101

127. PSYC 293E

128. SOCA 101

129. SOCA 232

130. SOCA 233

131. SOCA 235

132. SOWK 151

133. SPA 278

134. STAT 211

135. UNIV 101
Introduction to Psychology

SPTP:Trauma/Stress Management

Introduction to Sociology

Criminology

Juvenile Delinquency

Race Relations

Introduction to Social Work

Communication Disorders

Elemntry Statistical Inference

Orin:First-Year Experience 


\section{Appendix D}

Cover Letter and E-mails to Participants 


\section{WestVirginiaUniversity}

\section{College of Human Resources and Education}

$\begin{array}{ll}\text { TO: } & \text { ONLINE COURSE INSTRUCTORS } \\ \text { FROM: } & \text { JINSONG ZHANG, RICHARD WALLS } \\ \text { SUBJECT: } & \text { ONLINE INSTRUCTION SURVEY } \\ \text { DATE: } & \text { SEPTEMBER 6, 2005 }\end{array}$

Dear

I am Jinsong Zhang, a doctoral candidate in the College of Human Resources and Education, West Virginia University. Because of your active involvement in teaching online courses (__ ) I am requesting your participation in my dissertation research on online instruction. The research is conducted in partial fulfillment of the requirements for my doctorate. The purpose of the study is to investigate the experience of faculty members who are teaching online courses at West Virginia University during 2005. The research will require your participation only through the completion of a survey form about your use of SEVEN PRINCIPLES.

I obtained your name from the office of Admissions and Records after I received IRB Human Participant Exemption. Your participation in this study is completely voluntary, and you do not have to answer every question. All your responses will be kept anonymous and confidential throughout the study. Only the researcher and his advisor will have access to the data. The results of the research study may be published, but your identity will be kept anonymous. The course subject and course number will be removed soon after the courses are grouped into their categories. There will not be any way to trace your response.

The URL of the survey is http://simpleforms.scripts.wvu.edu/sf/7P_Survey/

If you prefer a paper-based survey, please send me an e-mail to let me know.

Feel free to ask any questions about this research and your participation in the study. You may contact the researcher either through the phone 304-293-0405 Ext 4205 (office), 717-977-0906 (cell), or e-mail jinsong.zhang@mail.wvu.edu.

Thank you for your contribution to this research. Please fill out your responses on the survey about your use of the SEVEN PRINCIPLES as soon as you can. Your participation is greatly appreciated. 


\section{Follow-up E-mail to Nonrespondents}

\section{SUBJECT: $\quad$ SURVEY ABOUT WVU ONLINE TEACHING (for my dissertation)}

Dear

I sent you a short note and a copy of IRB exemption approval through WVU campus mail /[post office] a couple of days ago. The mail was sent to PO Box /[address: ]. In this note I requested your favor of assisting me by completing an online survey about your online instruction practice. I am hoping you have already received the mail. This e-mail is just a friendly reminder to urge you to give me your kind help.

I received IRB Human Participant Protection Exemption and obtained your name from the office of Admissions and Records. Could you please click on this URL and fill out the Online Faculty Inventory? I greatly appreciate your help.

http://simpleforms.scripts.wvu.edu/sf/7P_Survey/

After filling out the form, please remember to click [Submit This Form] button. Thank you for your contribution to this research. Please fill out your responses on the survey about your use of the SEVEN PRINCIPLES as soon as you can. Disregard this message if you have completed the survey already.

Jinsong Zhang (Doctoral Student)

Richard Walls (Advisor) 


\title{
Second Follow-up E-mail to Nonrespondents
}

\author{
SUBJECT: Response Rate Too Low to Conclude Data Collection
}

Dear

I want to conclude the data-collecting phase of my dissertation research, but the response rate is still too low for me to do so. I have tried two different ways to get online faculty to fill out my questionnaire called "Online Faculty Inventory." Perhaps you have been very busy or perhaps you have just forgotten about it - if this is the case, please take some time from your already tight schedule to give me your kind assistance. I really need you help before I am able to proceed. I have enclosed the URL for your convenience and urge you to complete it this week.

http://simpleforms.scripts.wvu.edu/sf/7P_Survey/

If you have completed the survey, please just disregard this e-mail.

Sincerely,

Jinsong Zhang 


\section{E-mail to Clarify Onsite Instruction Hours}

SUBJECT: A question about Item\# 4 in Survey

Dear

Thank you very much for your help in completing the survey. When I start to analyze the data, I found a small question I want to clarify. For question \#4 "Student On-Campus Participation," you entered __ hours for ___ [course number \& title]. Since this is an online course, and a regular 3 credit hour class has only 51 hours (17 weeks by 3 hours), I was wondering whether my error has led to some sort of misunderstanding. I would appreciate it if you could give me some idea as how you performed the calculation.

Jinsong

P.S.

This e-mail might have reached you in error. If this is the case, please disregard this message. 


\section{Appendix E}

\section{Online Faculty Inventory*}

* The shaded items in the Online Faculty Inventory are taken directly from Faculty Inventory (Chickering et al., 1989) without modification. The inventory that the participants received was not shaded. 


\section{Online Faculty Inventory}

This inventory is designed for UNDERGRADUATE classes only. If you are teaching more than one class, please select just ONE. Thank you very much for your participation.

\section{A. Demographics}

1. Course Subject \& Number

Please supply both subject and number of the course (e.g., CS 101, PE392)

2. Instructor Classroom Teaching Experience

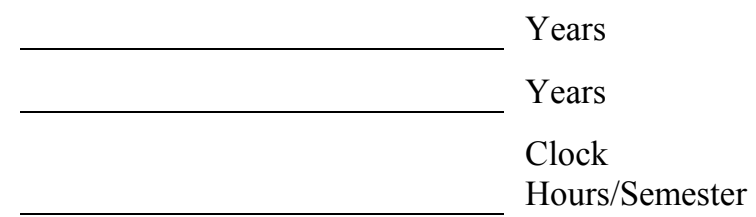

4. Student On-campus Participation Hours/Semester

Please indicate the total number of hours for all onsite instructional activities (e.g., initial training, tests, labs, discussions, and lectures) for the course you indicated in question A-1.

5. Instructor Age Years

6. Instructor Gender

Male

7. Highest Degree Obtained

Doctorate

$\square$ Master's

Other

8. Instructor Job

Classification

Staff

$\square$ Student

$\square$ Non-Tenure $\square$ Instructor

Track Faculty (Tenure

Track)

$\begin{aligned} & \text { Assistant } \\ & \text { Professor }\end{aligned}$
$\begin{aligned} & \text { Associate } \\ & \text { Professor }\end{aligned}$
$\begin{aligned} & \text { Other (Please } \\ & \text { specify) }\end{aligned}$

9. Class Size

Students

10. Instruction Delivery

Technology
Course Web site
$\square$ Interactive Network
Streaming Video
Streaming Audio
Other (Please
specify)

\section{B. Pedagogical Principles}

There are seven parts in this section, each corresponding to one of Seven Principles. The numbers to the right of an item indicate the range of your practice stated by that item in YOUR ONLINE CLASS. Number 1 indicates you never implement that strategy, and 5 
indicates you implement it very often. Please judge YOUR level of implementation of the Seven Principles by marking a number (1 to 5 ) for each item.

\section{Encourage Student-Faculty Contact}

1. I advise my students about career opportunities in their major field.

2. I share my past experiences, attitudes, and values with students.

3. I know my students by name by the end of the first two weeks of the term.

4. I serve as an informal advisor to students via e-mail.

5. I invite or take my students to attend professional meetings or other events in my field.

$\begin{array}{llll}\text { Never Rarely } & \begin{array}{l}\text { Occas } \\ \text { ionally }\end{array} & \text { Often } & \begin{array}{l}\text { Very } \\ \text { Often }\end{array}\end{array}$

1

2

3

4

5

12

3

4

5

1

2

3

4

5

1

2

3

4

5

1

2

\section{3}

4

5

6. Promote Implementation

What are the major factors that promote your implementation of the principle "Encourage Student-Faculty Contact"?

7. Hinder Implementation

What are the major factors that hinder your implementation of the principle "Encourage Student-Faculty Contact"?

\section{Encourage Cooperation Among Students}

$\begin{array}{llll}\text { Never Rarely } & \begin{array}{l}\text { Occas } \\ \text { ionally }\end{array} & \text { Often } & \begin{array}{c}\text { Very } \\ \text { Often }\end{array}\end{array}$

1. I encourage my students to prepare together for classes or exams.

2. I encourage students to do projects together.

3. I ask my students to evaluate each other's work.

4. I ask my students to discuss key concepts with other students whose backgrounds and viewpoints are different from their own. 
5. I create "learning communities," study groups, or project teams within my

1

$$
2
$$

3

4

5 courses.

\section{Promote Implementation}

What are the major factors that promote your implementation of the principle "Encourage Cooperation among Students"?

\section{Hinder Implementation}

What are the major factors that hinder your implementation of the principle "Encourage Cooperation among Students"?

\section{Encourage Active Learning}

1. I ask my students to relate outside events or activities to the subjects covered in my courses.

2. I encourage students to challenge my ideas, the ideas of other students, or those presented in readings or other course materials.

3. I give my students concrete, real-life situations to analyze.

Never Rarely $\begin{aligned} & \text { Occas } \\ & \text { ionally Often }\end{aligned}$

4. I encourage my students to suggest new readings, research projects, field trips, or other course activities.

5. I carry out research projects with my students.

$\begin{array}{lllll}1 & 2 & 3 & 4 & 5\end{array}$

$\begin{array}{lllll}1 & 2 & 3 & 4 & 5\end{array}$

$\begin{array}{lllll}1 & 2 & 3 & 4 & 5\end{array}$

$\begin{array}{lllll}1 & 2 & 3 & 4 & 5\end{array}$

$\begin{array}{lllll}1 & 2 & 3 & 4 & 5\end{array}$

6. Promote Implementation

What are the major factors that promote your implementation of the principle "Encourage Active Learning"?

\section{Hinder Implementation}

What are the major factors that hinder your implementation of the principle "Encourage Active Learning"? 


\section{Give Prompt Feedback}

1. I prepare online activities which give students immediate feedback on how well they do.

2. I return examinations and papers within a week.

3. I give students detailed evaluations of their work early in the term.

4. I ask my students to schedule conferences (phone calls, chat room, or on-campus) with me to discuss their progress.

5. I give my students written comments on their strengths and weaknesses on exams and papers.

\section{Promote Implementation}

What are the major factors that promote your implementation of the principle "Give Prompt Feedback"?
Never Rarely $\begin{aligned} & \text { Occas } \\ & \text { ionally Often }\end{aligned}$

$\begin{array}{lllll}1 & 2 & 3 & 4 & 5\end{array}$

$\begin{array}{lllll}1 & 2 & 3 & 4 & 5\end{array}$

$\begin{array}{lllll}1 & 2 & 3 & 4 & 5\end{array}$

$\begin{array}{lllll}1 & 2 & 3 & 4 & 5\end{array}$

$\begin{array}{lllll}1 & 2 & 3 & 4 & 5\end{array}$

5

5

\section{Hinder Implementation}

What are the major factors that hinder your implementation of the principle of "Give Prompt Feedback"?

\section{Emphasize Time on Task}

1. I expect my students to complete their assignments promptly.

2. I clearly communicate to my students the minimum amount of time they should spend preparing for classes.

3. I underscore the importance of regular work, steady application, sound selfpacing, and scheduling.

4. I contact students who fall behind to discuss their study habits, schedules, and other commitments.

5. If students miss my classes, I require them to make up lost work. 


\section{Promote Implementation}

What are the major factors that promote your implementation of the principle "Emphasize Time on Task"?

\section{Hinder Implementation}

What are the major factors that hinder your implementation of the principle "Emphasize Time on Task"?

\section{Communicate High Expectations}

$\begin{array}{cccc}\text { Never Rarely } & \begin{array}{l}\text { Occas } \\ \text { ionally Often }\end{array} & \begin{array}{c}\text { Very } \\ \text { Often }\end{array}\end{array}$

1. I tell students that I expect them to work hard in my classes.

$\begin{array}{lllll}1 & 2 & 3 & 4 & 5\end{array}$

2. I emphasize the importance of holding high standards for academic achievement.

3. I make clear my expectations in writing at the beginning of the course.

$\begin{array}{lllll}1 & 2 & 3 & 4 & 5\end{array}$

$\begin{array}{lllll}1 & 2 & 3 & 4 & 5\end{array}$

4. I help students set challenging goals for their own learning.

$\begin{array}{lllll}1 & 2 & 3 & 4 & 5\end{array}$

5. I explain to students what will happen if they do not complete their work on time.

$\begin{array}{lllll}1 & 2 & 3 & 4 & 5\end{array}$

6. Promote Implementation

What are the major factors that promote your implementation of the principle "Communicate High Expectations"?

\section{Hinder Implementation}

What are the major factors that hinder your implementation of the principle "Communicate High Expectations"?

\section{Respect Diverse Talents and Ways of Learning}

Never Rarely $\begin{aligned} & \text { Occas } \\ & \text { ionally Often }\end{aligned}$


1. I encourage students to speak up when they don't understand.

1

2. I use diverse teaching activities to address a broad spectrum of students.

3. I select readings and design activities related to the background of my students.

4. I integrate new knowledge about women and other under-represented populations into my courses.

5. I try to find out about my students' learning styles, interests or backgrounds at the beginning of each course.

$\begin{array}{lllll}1 & 2 & 3 & 4 & 5 \\ 1 & 2 & 3 & 4 & 5 \\ 1 & 2 & 3 & 4 & 5 \\ 1 & 2 & 3 & 4 & 5 \\ 1 & 2 & 3 & 4 & 5\end{array}$

6. Promote Implementation

What are the major factors that promote your implementation of the principle "Respect Diverse Talents and Ways of Learning"?

\section{Hinder Implementation}

What are the major factors that hinder your implementation of the principle "Respect Diverse Talents and Ways of Learning"? 
Appendix F

Expert Suggestion Form 


\section{Expert Suggestion Form}

\section{INSTRUCTION:}

The purpose of the study is to explore and describe the implementation of Chickering and Gamson's Seven Principles for Good Practice in Undergraduate Education in the online environment. The study attempts to (1) explore the instructors' perception of their practices, (2) determine factors that influence their implementation of the principles, and (3) discover the relationship between the factors and online implementation of the Seven Principles.

The questionnaire is based on Chickering, Gamson, and Barsi's Faculty Inventory. To use the inventory for an online course, the researcher removed or modified some items typical for the face-to-face environment. Items in the left column are from the original Faculty Inventory, and items in the right column are to be used in the study.

Based on your judgement, please indicate how an item in the RIGHT column can be improved or another item should be added. Thanks.

\section{Good Practice Encourages Student-Faculty Contact}

Original Item

1. I advise my students about career opportunities in their major field.

2. Students drop by my office just to visit.

3. I share my past experiences, attitudes, and values with students.

4. I attend events sponsored by student groups.

5. I work with student affairs staff on issues related to student extracurricular life and life outside school.

6. I know my students by name by the end of the first two weeks of the term.

7. I make special efforts to be available to students of a culture or race different from my own.

8. I serve as a mentor or informal advisor to students.

9. I take students to professional meetings or other events in my field.

10. Whenever there is a conflict on campus involving students, I try to help in its resolution.

\section{Online Faculty Inventory}

I advise my students about career opportunities in their major field.

Students call my office or e-mail me for casual talk.

I share my past experiences, attitudes, and values with students.

I work with student affairs staff on issues related to student extracurricular life and life outside school.

I know my students by name by the end of the first two weeks of the term.

I serve as an informal advisor to students via e-mail.

I invite my students to attend professional meetings or other events in my field.

\section{Good Practice Encourages Cooperation Among Students}

\section{Original Item}

1. I ask students to tell each other about their
Online Faculty Inventory

I arrange special chat room session for 
interests and backgrounds.

2. I encourage my students to prepare together for classes or exams.

3. I encourage students to do projects together. I encourage students to do projects together.

4. I ask my students to evaluate each other's work.

5. I ask my students to explain difficult ideas to each other.

6. I encourage my students to praise each other for their accomplishments.

7. I ask my students to discuss key concepts with other students whose backgrounds and viewpoints are different from their own.

8. I create "learning communities," study groups, or project teams within my courses.

9. I encourage students to join at least one campus organization.

10. I distribute performance criteria to students so that each person's grade is independent of those achieved by others.

\section{Good Practice Encourages Active Learning}

\section{Original Item}

1. I ask my students to present their work to the class.

2. I ask my students to summarize similarities and differences among different theorists, research findings, or artistic works.

3. I ask my students to relate outside events or activities to the subjects covered in my courses.

4. I ask my students to undertake research or independent study.

5. I encourage students to challenge my ideas, the ideas of other students, or those presented in readings or other course materials.

6. I give my students concrete, real-life situations to analyze.

7. I use simulations, role-playing, or labs in my classes.

8. I encourage my students to suggest new readings, research projects, field trips, or other course activities.

9. My students and I arrange field trips, students to get to know each other.

I encourage my students to prepare together for classes or exams.

I ask my students to explain difficult ideas to each other.

I encourage my students to praise each other for their accomplishments.

I create "learning communities," study groups, or project teams within my courses.

I distribute performance criteria to students so that each person's grade is independent of those achieved by others.

\section{Online Faculty Inventory}

I ask my students to publish their work in the course Web site.

I ask my students to summarize similarities and differences among different theorists, research findings, or artistic works.

I ask my students to relate outside events or activities to the subjects covered in my courses.

I ask my students to undertake research or independent study.

I encourage students to challenge my ideas, the ideas of other students, or those presented in readings or other course materials.

I give my students concrete, real-life situations to analyze.

I encourage my students to suggest new readings, research projects, field trips, or other course activities. 
volunteer activities, or internships related to the course.

10. I carry out research projects with my students.

\section{Good Practice Gives Prompt Feedback}

\section{Original Item}

1. I give quizzes and homework assignments.

2. I prepare classroom exercises and problems which give students immediate feedback on how well they do.

3. I return examinations and papers within a week.

4. I give students detailed evaluations of their work early in the term.

5. I ask my students to schedule conferences with me to discuss their progress.

6. I give my students written comments on their strengths and weaknesses on exams and papers.

7. I give my students a pre-test at the beginning of each course.

8. I ask students to keep logs or records of their progress.

9. I discuss the results of the final examination with my students at the end of the semester.

10. I call or write a note to students who miss classes.

\section{Good Practice Emphasizes Time on Task}

Original Item

1. I expect my students to complete their assignments promptly.

2. I clearly communicate to my students the minimum amount of time they should spend preparing for classes.

3. I make clear to my students the amount of time that is required to understand complex material.

4. I help students set challenging goals for their own learning.

5. When oral reports or class presentations are called for I encourage students to rehearse in advance.

\section{Online Faculty Inventory}

I give quizzes and homework assignments.

I prepare online activities, which give students immediate feedback on how well they do.

I return examinations and papers within a week.

I give students detailed evaluations of their work early in the term.

I ask my students to schedule conferences (phone calls, chat room, or on-campus) with me to discuss their progress.

I give my students written comments on their strengths and weaknesses on exams and papers.

I contact students who miss classes.

\section{Online Faculty Inventory}

I expect my students to complete their assignments promptly.

I clearly communicate to my students the minimum amount of time they should spend preparing for classes.

I make clear to my students the amount of time that is required to understand complex material.

I help students set challenging goals for their own learning. 
6. I underscore the importance of regular work, steady application, sound self-pacing, and scheduling.

7. I explain to my students the consequences of non-attendance.

I explain to my students the consequences of non-attendance.

8. I make it clear that full-time study is a fulltime job that requires forty or more hours a week.

I make it clear that full-time study is a fulltime job that requires forty or more hours a week.

9. I meet with students who fall behind to discuss their study habits, schedules, and other commitments.

10. If students miss my classes, I require them to make up lost work.

contact students who fall behind to discuss their study habits, schedules, and other commitments.

\section{Good Practice Communicates High Expectations}

\section{Original Item}

1. I tell students that I expect them to work hard in my classes.

2. I emphasize the importance of holding high standards for academic achievement.

3. I make clear my expectations orally and in writing at the beginning of each course.

4. I help students set challenging goals for their own learning.

5. I explain to students what will happen if they do not complete their work on time.

6. I suggest extra reading or writing tasks.

7. I encourage students to write a lot.

8. I publicly call attention to excellent performance by my students.

9. I revise my courses regularly.

10. I periodically discuss how well we are doing during the course of the semester.

\section{Online Faculty Inventory}

I tell students that I expect them to work hard in my classes.

I make clear my expectations in writing at the beginning of the course.

I help students set challenging goals for their own learning.

I explain to students what will happen if they do not complete their work on time.

I suggest extra reading or writing tasks.

I publish student work through course Web site.

I periodically discuss how well we are doing during the course of the semester.

\section{Good Practice Respects Diverse Talents and Ways of Learning}

\section{Original Item}

1. I encourage students to speak up when they don't understand.

2. I discourage snide remarks, sarcasm, kidding, and other class behaviors that may embarrass students.

3. I use diverse teaching activities to address a broad spectrum of students.

\section{Online Faculty Inventory}

I encourage students to speak up when they don't understand

I use diverse teaching activities to address a broad spectrum of students. 
4. I select readings and design activities related to the background of my students.

5. I provide extra material or exercises for students who lack essential background knowledge or skills.

6. I integrate new knowledge about women and other under-represented populations into my courses.

7. I make explicit provisions for students who wish to carry out independent studies within my own course or as separate courses.

8. I have developed mastery learning, learning contracts, or computer assisted learning alternatives for my courses.

9. I encourage my students to design their own majors when their interests warrant doing so.

10. I try to find out about my students' learning styles, interests or backgrounds at the beginning of each course.
I select readings and design activities related to the background of my students

I provide extra material or exercises for students who lack essential background knowledge or skills.

I integrate new knowledge about women and other under-represented populations into my courses.

I encourage my students to design their own majors when their interests warrant doing so.

I try to find out about my students' learning styles, interests or backgrounds at the beginning of each course. 


\section{Appendix G}

Cover Letter and Expert Response Form 


\title{
WestVirginiaUniversity
}

\section{College of Human Resources and Education}

\author{
TO: $\quad$ EXPERT PANEL MEMBERS \\ FROM: JINSONG ZHANG, RICHARD WALLS \\ SUBJECT: ONLINE INSTRUCTION SURVEY \\ DATE: $\quad 8 / 01 / 2005$
}

Dear Expert Panel Member,

I am Jinsong Zhang, a doctoral candidate at the College of Human Resources and Education, West Virginia University. I am requesting your participation in my dissertation research on online distance instruction. The research will require your participation in content validity evaluation. You are invited to participate in the evaluation because of your academic expertise and professional experience in instructional technology, online instruction, or measurement instrument.

The purpose of the study is to explore and describe the experience of West Virginia University faculty members teaching online courses. The study attempts to (1) explore the instructors' perception of their implementation of pedagogical principles, (2) determine factors that influence their implementation of the principles, and (3) discover the relationship between the factors and online implementation of the Seven Principles.

The enclosed questionnaire items were originally designed for conventional classroom instruction. To use it for an online course, some items typical for the face-to-face environment are removed or modified so that the items make sense for an online course.

The enclosed survey asks you to evaluate how representative and how clear the items are of the content domain of the Seven Principles for Good Education in Undergraduate Education (stated in the Response Form). That is, to what extent do you think that each question on the survey measures instructor implementation of the Seven Principles in the online environment?

You may call me through 304-293-0405 Ext 4205 (office) or 717-977-0906 (cell), or contact me through jinsong.zhang@mail.wvu.edu whenever you have a question.

Thank you for your cooperation. Your participation is greatly appreciated.

Jinsong Zhang
Richard T. Walls (Advisor) 


\section{Expert Response Form}

Name:

INSTRUCTIONS:

This measure is designed to evaluate the content validity of the instrument. Please indicate how appropriate each of the items for measuring the pedagogical principle as it is related to an ONLINE COURSE delivery. The level of representativeness and clarity is presented on a Likerttype scale of $1-4$. Space is provided for you to comment on the item or suggest revisions.

Purpose of the Survey

(1) To explore the instructors' perception of their implementation of pedagogical principles as defined by Chickering and Gamson (1987),

(2) To determine factors that influence their online implementation of the principles, and

(3) To discover the relationship between the factors and online implementation of Seven Principles.

A good item must be representative and clear.

$1=$ not usable

$2=$ item may be usable with major work on clarity and representativeness

$3=$ item may be usable with work on either clarity or representativeness (circle one)

$4=$ item is clear and representative of the principle

\section{Encourage Student-Faculty Contact}

$\begin{array}{llllll}1 . & \text { I advise my students about career opportunities in their major field. } & & 2 & 3 & 4\end{array}$

Comments

2. Students call my office or e-mail me for casual talk.

$1223 \quad 4$

Comments

3. I share my past experiences, attitudes, and values with students.

$\begin{array}{llll}1 & 2 & 3 & 4\end{array}$

Comments

4. I work with student affairs staff on issues related to student extracurricular

$123 \quad 3 \quad 4$ life and life outside school.

Comments

5. I know my students by name by the end of the first two weeks of the term. $\begin{array}{llll}1 & 2 & 3 & 4\end{array}$

Comments

6. I serve as an informal advisor to students via e-mail.

$\begin{array}{llll}1 & 2 & 3 & 4\end{array}$

Comments

7. I invite or take my students to attend professional meetings or other

$1253 \quad 4$ events in my field.

\section{Encourage Cooperation Among Students}

$\begin{array}{llllll}1 . & \text { I ask students to tell each other about their interests and backgrounds. } & & 2 & 3 & 4\end{array}$ 
2. I encourage my students to prepare together for classes or exams.

3. I encourage students to do projects together.

4. I ask my students to evaluate each other's work.

5. I ask my students to explain difficult ideas to each other.

6. I encourage my students to praise each other for their accomplishments.

7. I ask my students to discuss key concepts with other students whose backgrounds and viewpoints are different from their own.

8. I create "learning communities," study groups, or project teams within my courses.

9. I encourage students to be involved in their professional organizations.

10. I distribute performance criteria to students so that each person's grade is independent of those achieved by others.

\section{Encourage Active Learning}

1. I ask my students to publish their work on the course Web site.

2. I ask my students to summarize similarities and differences among different theorists, research findings, or artistic works.

3. I ask my students to relate outside events or activities to the subjects covered in my courses.

4. I ask my students to undertake research or independent study.

5. I encourage students to challenge my ideas, the ideas of other students, or those presented in readings or other course materials.

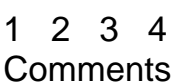

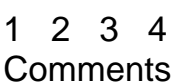

$\begin{array}{llll}1 & 2 & 3 & 4\end{array}$

Comments

$\begin{array}{llll}1 & 2 & 3 & 4\end{array}$

Comments

$\begin{array}{llll}1 & 2 & 3 & 4\end{array}$

Comments

$\begin{array}{llll}1 & 2 & 3 & 4\end{array}$

Comments

$\begin{array}{llll}1 & 2 & 3 & 4\end{array}$

Comments

$\begin{array}{llll}1 & 2 & 3 & 4\end{array}$

Comments

$\begin{array}{llll}1 & 2 & 3 & 4\end{array}$

Comments

$\begin{array}{llll}1 & 2 & 3 & 4\end{array}$

Comments

Comments

$\begin{array}{llll}1 & 2 & 3 & 4\end{array}$

$\begin{array}{llll}1 & 2 & 3 & 4\end{array}$ Comments

$\begin{array}{llll}1 & 2 & 3 & 4\end{array}$

Comments

$\begin{array}{llll}1 & 2 & 3 & 4\end{array}$

Comments

$\begin{array}{llll}1 & 2 & 3 & 4\end{array}$ 
Comments

6. I give my students concrete, real-life situations to analyze.

$\begin{array}{llll}1 & 2 & 3 & 4\end{array}$

Comments

7. I use simulations, role-playing, or labs in my classes.

$\begin{array}{llll}1 & 2 & 3 & 4\end{array}$

Comments

8. I encourage my students to suggest new readings, research projects, field

$1253 \quad 4$ trips, or other course activities.

Comments

9. My students and I arrange field trips, volunteer activities, or internships

$123 \quad 3 \quad 4$ related to the course.

Comments

10. I carry out research projects with my students.

$\begin{array}{llll}1 & 2 & 3 & 4\end{array}$

Comments

\section{Give Prompt Feedback}

1. I give quizzes and homework assignments.

$\begin{array}{llll}1 & 2 & 3 & 4\end{array}$

Comments

2. I prepare online activities which give students immediate feedback on how $\quad \begin{array}{llll}1 & 2 & 3 & 4\end{array}$ well they do.

Comments

3. I return examinations and papers within a week.

$\begin{array}{llll}1 & 2 & 3 & 4\end{array}$

Comments

4. I give students detailed evaluations of their work early in the term.

$1253 \quad 4$

Comments

5. I ask my students to schedule conferences (phone calls, chat room, or on- $\quad \begin{array}{llll}1 & 2 & 3 & 4\end{array}$ campus) with me to discuss their progress.

Comments

6. I give my students written comments on their strengths and weaknesses

$123 \quad 3 \quad 4$ on exams and papers.

Comments

7. I give my students a pre-test at the beginning of each course.

$\begin{array}{llll}1 & 2 & 3 & 4\end{array}$

Comments

8. I ask students to keep logs or records of their progress.

$\begin{array}{llll}1 & 2 & 3 & 4\end{array}$

Comments

9. I discuss the results of the final examination with my students at the end of $\begin{array}{llll}1 & 2 & 3 & 4\end{array}$ 
the semester.

10. I contact students who miss classes.

$\begin{array}{llll}1 & 2 & 3 & 4\end{array}$

Comments

\section{Emphasize Time on Task}

1. I expect my students to complete their assignments promptly.

2. I clearly communicate to my students the minimum amount of time they should spend preparing for classes.

$123 \quad 3 \quad 4$

Comments

3. I make clear to my students the amount of time that is required to understand complex material.

$123 \quad 3 \quad 4$

Comments

4. I help students set challenging goals for their own learning.

$\begin{array}{llll}1 & 2 & 3 & 4\end{array}$ Comments

5. I underscore the importance of regular work, steady application, sound self-pacing, and scheduling.

$123 \quad 3 \quad 4$

Comments

6. I explain to my students the consequences of non-attendance.

$\begin{array}{llll}1 & 2 & 3 & 4\end{array}$ Comments

7. I make it clear that full-time study is a full-time job that requires forty or

$\begin{array}{llll}1 & 2 & 3 & 4\end{array}$ more hours a week.

Comments

8. I contact students who fall behind to discuss their study habits, schedules, $\quad \begin{array}{lllll}1 & 2 & 3 & 4\end{array}$ and other commitments.

Comments

9. If students miss my classes, I require them to make up lost work.

$\begin{array}{llll}1 & 2 & 3 & 4\end{array}$

Comments

\section{Communicate High Expectations}

1. I tell students that I expect them to work hard in my classes. $\quad \begin{array}{lll}1 & 2 & 3\end{array}$

Comments

2. I emphasize the importance of holding high standards for academic $\quad \begin{array}{lllll}1 & 2 & 3 & 4\end{array}$ achievement.

Comments

3. I make clear my expectations in writing at the beginning of the course. $\quad \begin{array}{llll}1 & 2 & 3 & 4\end{array}$ 
4. I help students set challenging goals for their own learning.

5. I explain to students what will happen if they do not complete their work on $\begin{array}{lllll}1 & 2 & 3 & 4\end{array}$ time.

Comments

6. I suggest extra reading or writing tasks.

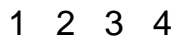

Comments

7. I encourage students to write a lot.

$\begin{array}{llll}1 & 2 & 3 & 4\end{array}$

Comments

8. I publish exemplary student work through the course Web site.

$\begin{array}{llll}1 & 2 & 3 & 4\end{array}$

Comments

9. I revise my courses regularly.

$123 \quad 3 \quad 4$

Comments

10. I periodically discuss how well we are doing during the course of the

$123 \quad 3 \quad 4$ semester.

Comments

\section{Respect Diverse Talents and Ways of Learning}

1. I encourage students to speak up when they don't understand.

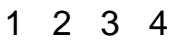

Comments

2. I use diverse teaching activities to address a broad spectrum of students. $\begin{array}{llll}1 & 2 & 3 & 4\end{array}$ Comments

3. I select readings and design activities related to the background of my students.

$123 \quad 3 \quad 4$

Comments

4. I provide extra material or exercises for students who lack essential background knowledge or skills.

$123 \quad 3 \quad 4$

Comments

5. I integrate new knowledge about women and other under-represented populations into my courses.

$123 \quad 3 \quad 4$

Comments

6. I have developed mastery learning, learning contracts, or computer $\quad \begin{array}{llll}1 & 2 & 3 & 4\end{array}$ assisted learning alternatives for my courses.

Comments 
7. I encourage my students to design their own majors when their interests warrant doing so.

$123 \quad 3 \quad 4$

Comments

8. I try to find out about my students' learning styles, interests or

$123 \quad 3 \quad 4$ backgrounds at the beginning of each course.

Comments 
Appendix $\mathrm{H}$

Content Validity Study of the Instrument 


\section{Content Validity Study}

\begin{tabular}{|c|c|c|c|c|c|c|c|c|c|c|}
\hline Item & $\begin{array}{c}\text { Judge } \\
1 \\
\end{array}$ & $\begin{array}{c}\text { Judge } \\
2 \\
\end{array}$ & $\begin{array}{c}\text { Judge } \\
3 \\
\end{array}$ & $\begin{array}{c}\text { Judge } \\
4 \\
\end{array}$ & $\begin{array}{c}\text { Judge } \\
5 \\
\end{array}$ & $\begin{array}{c}\text { Judge } \\
6 \\
\end{array}$ & $\begin{array}{c}\text { Judge } \\
7 \\
\end{array}$ & $\mathrm{M}$ & $\mathrm{IRA}^{*}$ & $\mathrm{CVI}^{+}$ \\
\hline 1.1 & 4 & 2 & 4 & 2 & 4 & 4 & 3 & 3.29 & 0.71 & 0.71 \\
\hline 1.2 & 4 & 4 & 4 & 4 & 4 & 4 & 3 & 3.86 & 1.00 & 1.00 \\
\hline 1.3 & 4 & 3 & 4 & 4 & 4 & 4 & 4 & 3.86 & 1.00 & 1.00 \\
\hline 1.4 & 4 & 4 & 4 & 3 & 1 & 4 & 4 & 3.43 & 0.86 & 0.86 \\
\hline 1.5 & 4 & 4 & 4 & 2 & 4 & 4 & 4 & 3.71 & 0.86 & 0.86 \\
\hline 2.1 & 4 & 4 & 4 & 4 & 4 & 4 & 4 & 4.00 & 1.00 & 1.00 \\
\hline 2.2 & 4 & 4 & 4 & 4 & 4 & 4 & 4 & 4.00 & 1.00 & 1.00 \\
\hline 2.3 & 4 & 2 & 4 & 4 & 4 & 4 & 4 & 3.71 & 0.86 & 0.86 \\
\hline 2.4 & 4 & 2 & 4 & 4 & 4 & 4 & 4 & 3.71 & 0.86 & 0.86 \\
\hline 2.5 & 4 & 4 & 3 & 4 & 4 & 4 & 4 & 3.86 & 1.00 & 1.00 \\
\hline 3.1 & 4 & 4 & 4 & 4 & 4 & 4 & 4 & 4.00 & 1.00 & 1.00 \\
\hline 3.2 & 4 & 4 & 4 & 4 & 4 & 4 & 4 & 4.00 & 1.00 & 1.00 \\
\hline 3.3 & 4 & 4 & 4 & 4 & 4 & 4 & 4 & 4.00 & 1.00 & 1.00 \\
\hline 3.4 & 4 & 4 & 4 & 4 & 1 & 4 & 4 & 3.57 & 0.86 & 0.86 \\
\hline 3.5 & 4 & 4 & 4 & 2 & 4 & 4 & 4 & 3.71 & 0.86 & 0.86 \\
\hline 4.1 & 4 & 4 & 4 & 4 & 4 & 3 & 4 & 3.86 & 1.00 & 1.00 \\
\hline 4.2 & 4 & 2 & 4 & 4 & 4 & 4 & 4 & 3.71 & 0.86 & 0.86 \\
\hline 4.3 & 4 & 4 & 4 & 3 & 4 & 4 & 4 & 3.86 & 1.00 & 1.00 \\
\hline 4.4 & 4 & 4 & 4 & 3 & 4 & 4 & 4 & 3.86 & 1.00 & 1.00 \\
\hline 4.5 & 4 & 4 & 4 & 4 & 4 & 4 & 2 & 3.71 & 0.86 & 0.86 \\
\hline 5.1 & 4 & 4 & 4 & 4 & 1 & 4 & 4 & 3.57 & 0.86 & 0.86 \\
\hline 5.2 & 4 & 2 & 4 & 3 & 4 & 4 & 4 & 3.57 & 0.86 & 0.86 \\
\hline 5.3 & 4 & 4 & 4 & 4 & 4 & 4 & 2 & 3.71 & 0.86 & 0.86 \\
\hline 5.4 & 4 & 4 & 4 & 4 & 4 & 4 & 3 & 3.86 & 1.00 & 1.00 \\
\hline 5.5 & 4 & 2 & 4 & 3 & 4 & 3 & 3 & 3.29 & 0.86 & 0.86 \\
\hline 6.1 & 4 & 4 & 4 & 4 & 4 & 4 & 2 & 3.71 & 0.86 & 0.86 \\
\hline 6.2 & 4 & 4 & 4 & 4 & 4 & 4 & 4 & 4.00 & 1.00 & 1.00 \\
\hline 6.3 & 4 & 4 & 4 & 4 & 4 & 4 & 3 & 3.86 & 1.00 & 1.00 \\
\hline 6.4 & 4 & 4 & 4 & 4 & 4 & 4 & 4 & 4.00 & 1.00 & 1.00 \\
\hline 6.5 & 4 & 4 & 4 & 4 & 1 & 3 & 3 & 3.29 & 0.86 & 0.86 \\
\hline 7.1 & 4 & 4 & 4 & 3 & 4 & 2 & 3 & 3.43 & 0.86 & 0.86 \\
\hline 7.2 & 4 & 4 & 4 & 4 & 4 & 4 & 3 & 3.86 & 1.00 & 1.00 \\
\hline 7.3 & 4 & 4 & 4 & 4 & 4 & 3 & 2 & 3.57 & 0.86 & 0.86 \\
\hline 7.4 & 4 & 2 & 4 & 4 & 4 & 2 & 3 & 3.29 & 0.71 & 0.71 \\
\hline 7.5 & 4 & 4 & 4 & 4 & 4 & 4 & 4 & 4.00 & 1.00 & 1.00 \\
\hline cale & & & & & & & & 3.73 & $0.94^{\ddagger}$ & $0.92^{\S}$ \\
\hline
\end{tabular}

${ }^{*}$ IRA $=$ Agreement $/$ Expert panel size

${ }^{\dagger} \mathrm{CVI}=$ Number of experts giving 3 or $4 /$ Expert panel Size

${ }^{*}$ IRA(Scale) $=$ Number of items with $80 \%$ reliability/Number of items in scale

${ }^{\S} \mathrm{CVI}(\mathrm{Scale})=\mathrm{Numb}$ of items rated as usable by all/Number of items in scale 
Appendix I

Pilot-Survey E-mail Message and Screenshot 


\section{Pilot Survey E-mail Message}

Dear Dr

From the office of Admissions and Records, I found you are teaching through the Internet. I believe you will be able to assist me with my dissertation research and I am asking your favor by participating in a pilot-survey to help improve my questionnaire before I undertake the final dissertation study.

Could you please click on this URL and fill out the Online Faculty Inventory? I greatly appreciate your help.

http://simpleforms.scripts.wvu.edu/sf/jszhang/

1. Please fill out the questionnaire;

2. Please indicate those questions you believe are poorly worded, ambiguous, or unanswerable for an online instructor in the "Comments and Suggestions" textbox at the end of the questionnaire. Specify changes that you believe would correct any problems, and you should feel free to suggest other questions;

3. Click [Submit This Form].

IRB approval has been obtained for my research. Wish you a wonderful day.

Jinsong Zhang (Doctoral Student)

Richard Walls (Advisor) 


\section{Pilot Survey Screenshot}

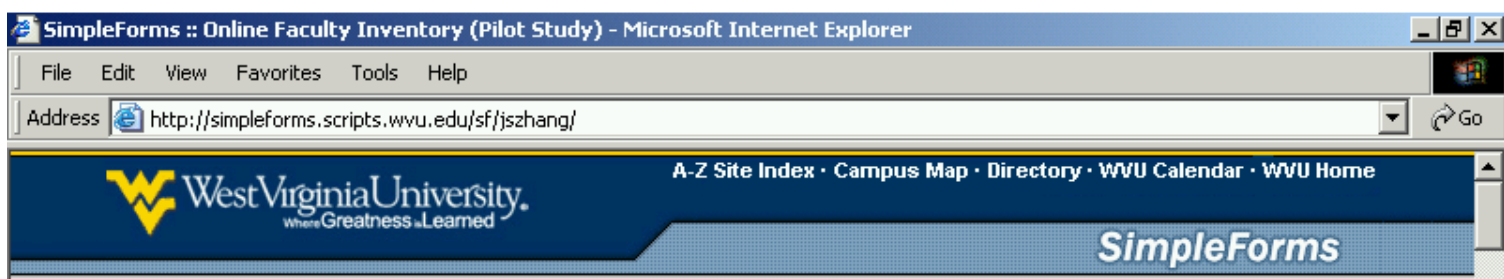

\section{Online Faculty Inventory (Pilot Study)}

This inventory is designed for one class only. If you are teaching more than one class, please select just ONE. Thankyou very much for your participation.

\section{A. Demographics}

1. Course Subject \& Number Please supply both subject and number of the course you are teaching (e.g., CS 101 , COMM201)

2. Instructor classroom teaching experience (Years)

3. Instructor online teaching experience (Years)

4. Student on-campus participation (Hours/Semester)

Please indicate the total number of hours for all onsite instructional activities (e.g., initial training, tests, labs, discussions, and lectures).

5. Instructor age (Years)

6. Instructor gender

$C$ Male

C Female

7. Highest degree obtained

Doctorate

$C$ Master's

Bachelor's

$C$ other

If 'Other' please specify:

Full Professor

$C$ Associate Professor

C Assistant Professor

Instructor

\section{Class size (Students)}

10 Technology
$\Gamma$ Course Website
Г Interactive Network
$\Gamma$ Streaming Video
$\Gamma$ Streaming Audio
$\Gamma$ other

If 'Other' please specify: 


\section{B. Pedagogical Principles}

There are seven parts in this section, each corresponding to one of Seven Principles. The number to the right of an item indicates the range of your practice stated by that item in YOUR ONLINE CLASS. Number 1 indicates you never implement that strategy, and 5 indicates you implement it very often. Please judge YOUR level of implementation of the Seven Principles by marking a number ( 1 to 5$)$ for each item.

\section{Encourage Student-Faculty Contact}

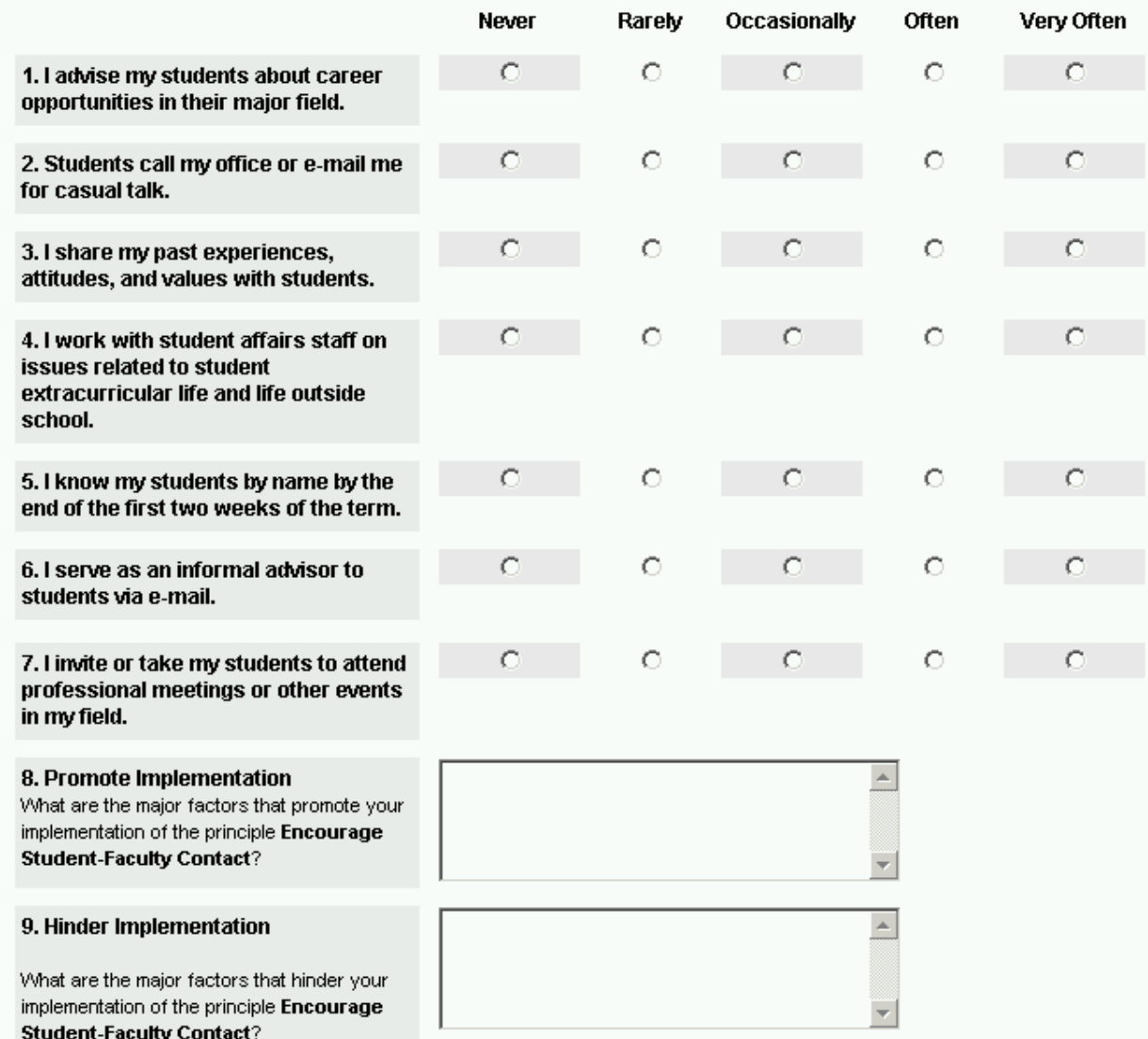

2. Encourage Cooperation Among Students

\section{I ask students to tell each other about their interests and backgrounds. \\ 2. I encourage my students to prepare together for classes or exams.}

3. I encourage students to do projects together.

4. I ask my students to evaluate each other's work.

5. I ask my students to explain difficult ideas to each other.

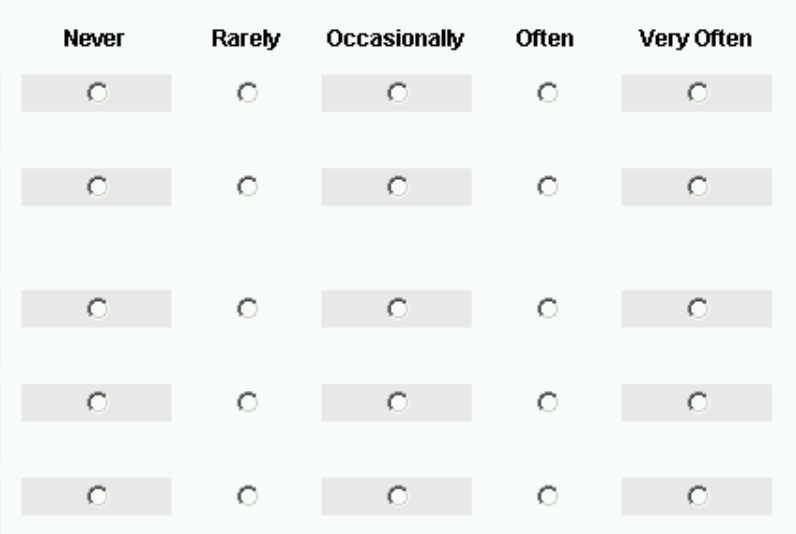


6. I encourage my students to praise each other for their accomplishments.

\section{I ask my students to discuss key concepts with other students whose backgrounds and viewpoints are} different from their own.

8. I create "learning communities," study groups, or project teams within my courses.

9. I encourage students to be imolved in their professional organizations.

10. I distribute performance criteria to students so that each person's grade is independent of those achieved by others.

11. Promote Implementation What are the major factors that promote your implementation of the principle Encourage Cooperation among Students?

12. Hinder Implementation

What are the major factors that hinder your implementation of the principle Encourage Cooperation among Students?

3. Encourage Active Learning

1. I ask my students to publish their work in the course website.

2. I ask my students to summarize similarities and differences among different theorists, research findings, or artistic works.

3. I ask my students to relate outside events or activities to the subjects covered in my courses.

4. I ask my students to undertake research or independent study.

5. I encourage students to challenge my ideas, the ideas of other students, or those presented in readings or other course materials.

6. I give my students concrete, real-life situations to analyze.

7. I use simulations, role-playing, or labs in my classes.

8. I encourage my students to suggest new readings, research projects, field trips, or other course activities.

9. Wy students and I arrange field trips, volunteer activities, or internships related to the course.
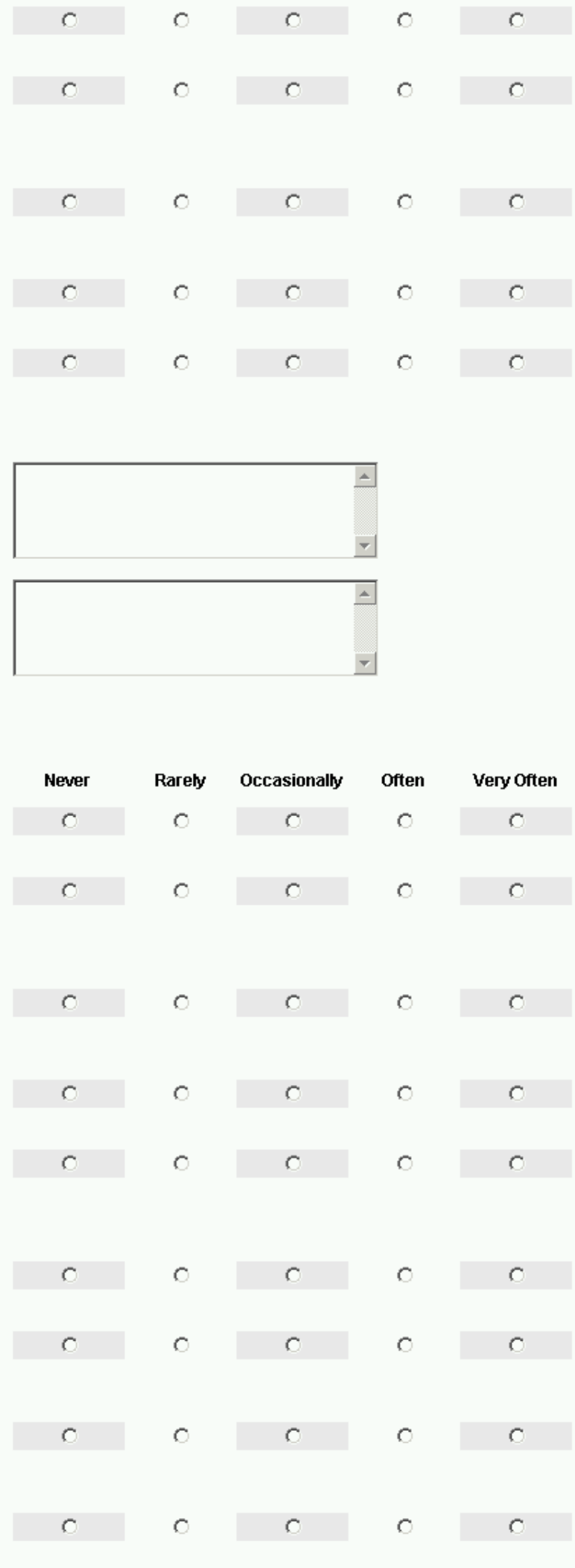
10. I carry out research projects with my students.

11. Promote Implementation

What are the major factors that promote your implementation of the principle Encourage Active Learning?

12. Hinder Implementation

What are the major factors that hinder your implementation of the principle Encourage Active Learning?

4. Give Prompt Feedback

1. I give quizzes and homework assignments.

2. I prepare online activities which give students immediate feedback on how well they do.

3. I return examinations and papers within a week.

4. I give students detailed evaluations of their work early in the term.

5. I ask my students to schedule conferences (phone calls, chat room, or on-campus) with me to discuss their progress.

6. I give my students written comments on their strengths and weaknesses on exams and papers.

7. I give my students a pre-test at the beginning of each course.

8. I ask students to keep logs or records of their progress.

9. I discuss the results of the final examination with my students at the end of the semester.

10. I contact students who miss classes.

11. Promote Implementation What are the major factors that promote your implementation of the principle of Giving Prompt Feedback.

12. Hinder Implementation

What are the major factors that hinder your implementation of the principle of Giving Prompt Feedback

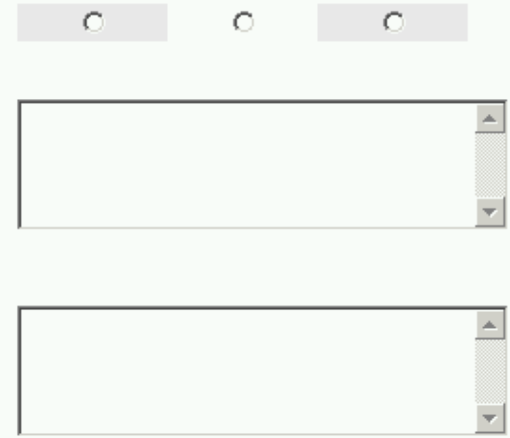

C

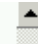

\section{$-$}$$
\text { . }
$$

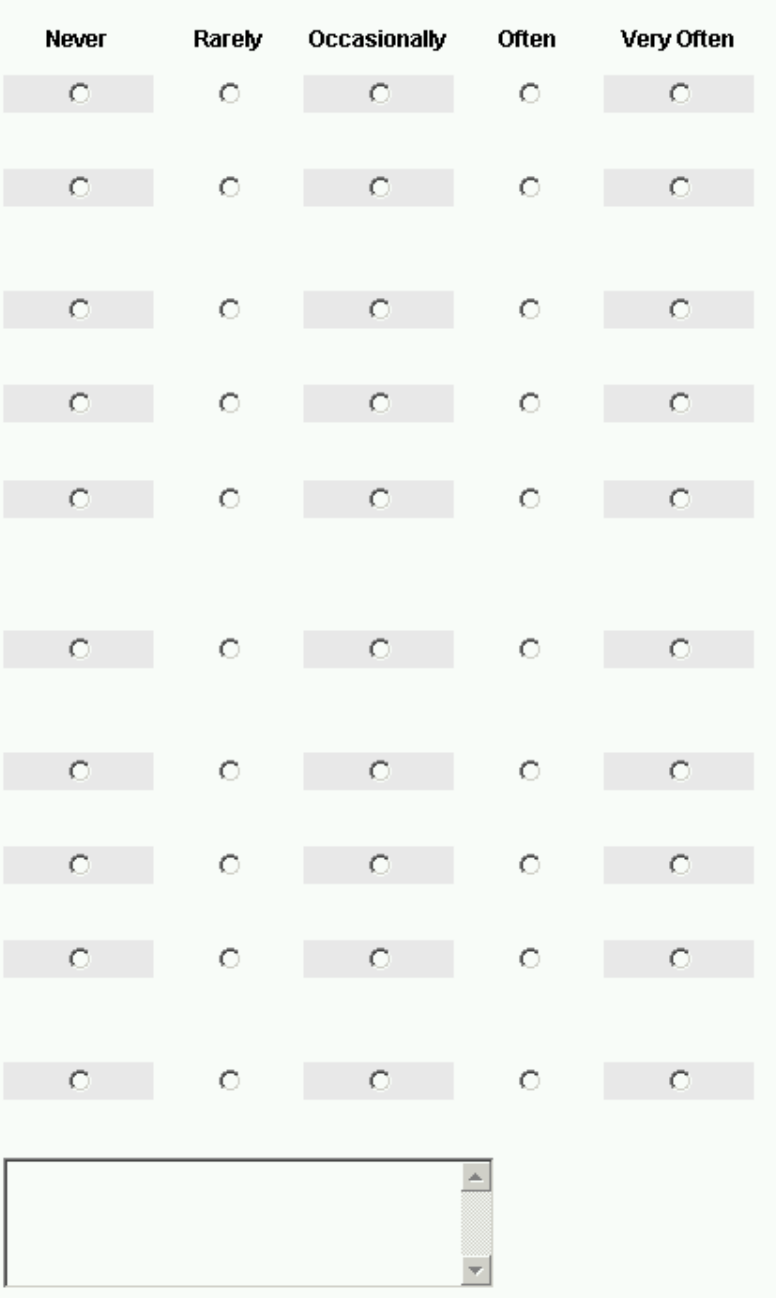


5. Emphasize Time on Task

1. I expect my students to complete
their assignments promptly.
2. I clearly communicate to my
students the minimum amount of time
they should spend preparing for
classes.
3. I make clear to my students the
amount of time that is required to
understand complex material.

4. I help students set challenging goals for their own learning.

5. I underscore the importance of regular work, steady application, sound self-pacing, and scheduling.

6. I explain to my students the consequences of non-attendance.

7. I make it clear that full-time stucty is a full-time job that requires forty or more hours a week.

8. I contact students who fall behind to discuss their study habits, schedules, and other commitments.

9. If students miss my classes, I require them to make up lost work.

10. Promote Implementation

What are the major factors that promote your implementation of the principle Emphasize Time on Task?

11. Hinder Implementation

What are the major factors that hinder your implementation of the principle Emphasize Time on Task?

\section{Communicate High Expectations}

1. I tell students that I expect them to work hard in my classes.

2. I emphasize the importance of holding high standards for academic achievement.

3. I make clear my expectations in writing at the beginning of the course.

4. I help students set challenging goals for their own learning.

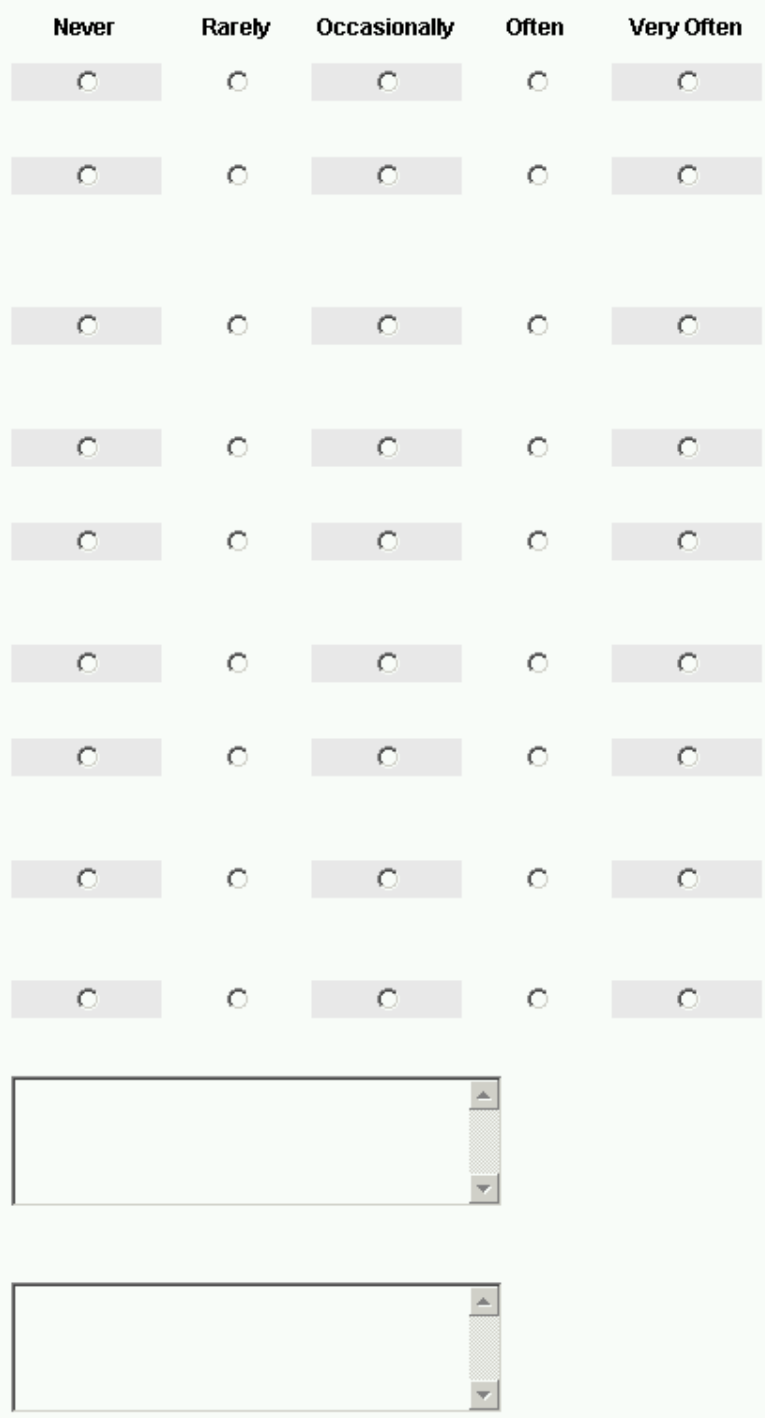

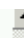


5. I explain to students what will work on time.

6. I suggest extra reading or writing tasks.

7. I encourage students to write a lot.

8. I publish exemplary student work through course website.

9. I revise my courses regularly.

10. I periodically discuss how well we are doing during the course of the semester.

11. Promote Implementation

What are the major factors that promote your implementation of the principle

Communicate High Expectations?

12. Hinder Implementation What are the major factors that hinder your implementation of the principle Communicate High Expectations? happen if they do not complete their

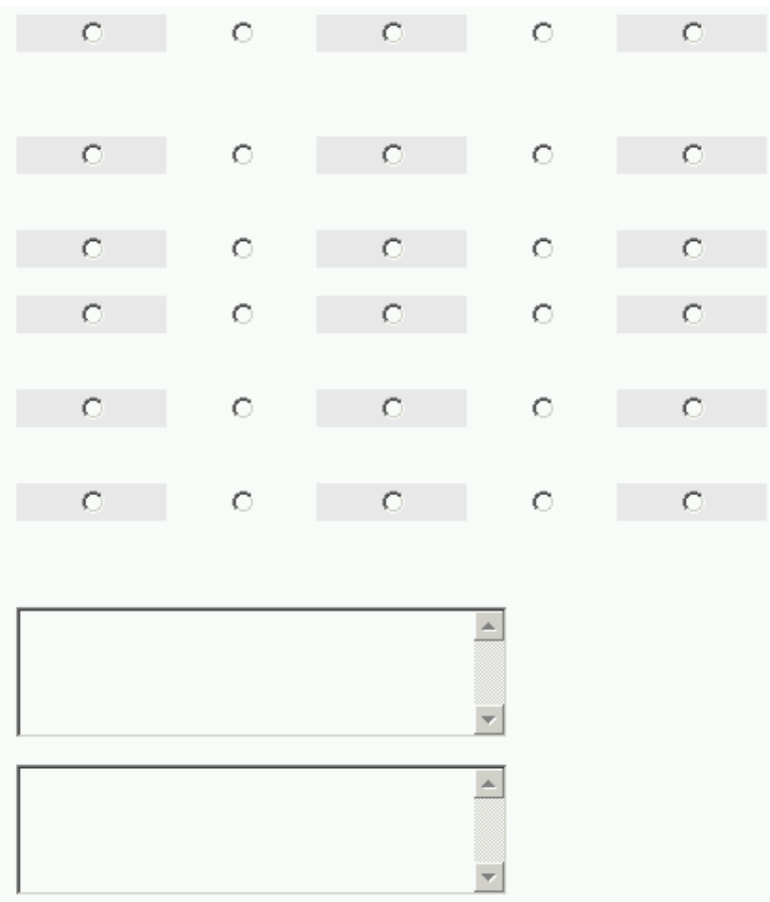

7. Respect Diverse Talents and Wavs of Learning

1. I encourage students to speak up when they don't understand.

2. I use diverse teaching activities to address a broad spectrum of students.

3. I select readings and design activities related to the background of my students.

4. I provide extra material or exercises for students who lack essential background knowledge or skills.

5. I integrate new knowledge about women and other under-represented populations into my courses.

6. I have developed mastery learning, learning contracts, or computer assisted learning alternatives for $\mathrm{my}$ courses.

7. I encourage my students to design their own majors when their interests warrant doing so.

\begin{tabular}{|c|c|c|c|c|}
\hline Never & Rarely & Occasionally & Often & Very Often \\
\hline $\mathrm{C}$ & $\mathrm{O}$ & $\mathrm{C}$ & 0 & $\mathrm{C}$ \\
\hline$C$ & $\mathrm{O}$ & $\mathrm{C}$ & $\mathrm{O}$ & $\mathrm{C}$ \\
\hline $\mathrm{C}$ & $\mathrm{O}$ & $\mathrm{C}$ & $\mathrm{O}$ & $\mathrm{C}$ \\
\hline $\mathrm{C}$ & $\mathrm{O}$ & $\mathrm{C}$ & $\mathrm{C}$ & $\mathrm{C}$ \\
\hline$C$ & 0 & $\mathrm{C}$ & $\mathrm{O}$ & $\mathrm{C}$ \\
\hline $\mathrm{C}$ & $\mathrm{C}$ & $\mathrm{C}$ & $\mathrm{O}$ & $\mathrm{C}$ \\
\hline $\mathrm{C}$ & $\mathrm{C}$ & $\mathrm{C}$ & $\mathrm{C}$ & $\mathrm{C}$ \\
\hline
\end{tabular}


8. I try to find out about my students'

C

C

C

C learning styles, interests or

backgrounds at the beginning of each course.

9. Promote Implementation

What are the major factors that promote your implementation of the principle Respect Diverse Talents and Ways of Learning?

10. Hinder Implementation

What are the major factors that hinder your implementation of the principle of Respect Diverse Talents and Ways of Learning?

Please leave your comments and suggestions below. Thanks.

Comments and Suggestions

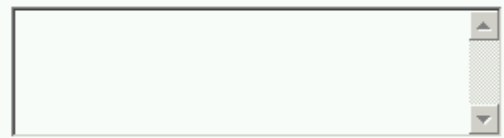

Submit This Form 
CURRICULUM VITA

\author{
Graduate School \\ West Virginia University
}

\author{
Name: $\quad$ Jinsong Zhang \\ Address: $\quad 102$ Curtis Avenue, Newburg, PA 17240-9226 \\ E-mail: $\quad$ jinsong.zhang@hotmail.com \\ Southwest Jiaotong University \\ Emei, Sichuan, China \\ March 1978 - October 1978 \\ Changsha Tiedao University \\ Changsha, Hunan, China \\ Bachelor of Arts in English, June 1982 \\ Southwest China Normal University \\ Chongqing, China \\ Master of Arts in English, May 1995 \\ Southern Illinois University at Carbondale \\ Carbondale, IL, U.S.A. \\ Master of Science in Computer Science, May 2002 \\ West Virginia University \\ Morgantown, WV, U.S.A. \\ Doctor of Education, December 2005
}

